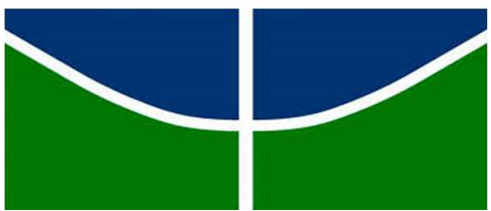

UNIVERSIDADE DE BRASÍLIA - UNB

FACULDADE DE ECONOMIA, ADMINISTRAÇÃO E CONTABILIDADE - FACE MESTRADO EM ECONOMIA E GESTÃO DO SETOR PÚBLICO

ANÁLISE DA QUALIDADE DA PRESTAÇÃO DE SERVIÇO NO INSTITUTO DE PESQUISA ECONOMICA APLICADA SOB A ÓTICA DA GOVERNANÇA

CORPORATIVA

MANOEL DE RIBAMAR CARDOSO BARROSO

BRASÍLIA, DEZEMBRO/2016 
MANOEL DE RIBAMAR CARDOSO BARROSO

\section{ANÁLISE DA QUALIDADE DA PRESTAÇÃO DE SERVIÇO NO INSTITUTO DE PESQUISA ECONOMICA APLICADA SOB A ÓTICA DA GOVERNANÇA CORPORATIVA}

Dissertação de Mestrado apresentada à Faculdade de Economia, Administração e Contabilidade (FACE), como requisito para obtenção de título de Mestre em Economia e Gestão do Setor Público.

ÁREA DE CONCENTRAÇÃO: Economia e Gestão do Setor Público

Orientador: $\operatorname{Prof}^{\mathrm{o}} \operatorname{Dr}^{\mathrm{o}}$ Alexandre MaduroAbreu 
UNIVERSIDADE DE BRASÍLIA - UNB

FACULDADE DE ECONOMIA, ADMINISTRAÇÃO E CONTABILIDADE - FACE MESTRADO EM ECONOMIA E GESTÃO DO SETOR PÚBLICO

MANOEL DE RIBAMAR CARDOSO BARROSO

ANÁLISE DA QUALIDADE DA PRESTAÇÃO DE SERVIÇO NO INSTITUTO DE PESQUISA ECONOMICA APLICADA SOB A ÓTICA DA GOVERNANÇA CORPORATIVA

Banca Examinadora:

$\operatorname{Prof}^{\circ} \operatorname{Dr}^{\circ}$ Alexandre Maduro-Abreu

Orientador

Prof $^{0}$ Dr $^{\circ}$ Adolfo Sachsida

Prof $^{\circ}$ Dr $^{\circ}$ Antonio Nascimento Junior

$\operatorname{Prof}^{\circ} \operatorname{Dr}^{\circ}$ Mireya Eugênia V. Parafán

Suplente

Data da Aprovação:

1




\section{AGRADECIMENTOS}

Aos meus colgas de trabalho do IPEA que enfrentaram esses dois anos de estudo com muita com muita dedicação e respeitos às diferenças.

Ao IPEA pela oportunidade que dada de poder ser um mestre e contribuir da melhor forma possível com meu país. 


\section{DEDICATÓRIA}

Dedico esta conquista à minha família.

Minha esposa Geórgila, pelo incentivo, apoio irrestrito, suporte emocional, mas principalmente por seu amor.

Meus filhos Gledson e Mayara, por me encherem de entusiasmo e felicidade e por darem o maior sentido à minha vida.

Minha mãe, Antônia Torres Cardoso, pelo exemplo de dedicação e humanismo e pelo apoio incondicional em todos os momentos. 


\section{LISTA DE SIGLAS}

$\begin{array}{ll}\text { IPEA } & \text { Instituto de Pesquisa Econômica Aplicada } \\ \text { IBGC } & \text { Instituto Brasileiro de Governança Corporativa } \\ \text { CVM } & \text { Comissão de Valores Mobiliários } \\ \text { TCU } & \text { Tribunal de Contas da União } \\ \text { OCDE } & \text { Organização para a Cooperação e Desenvolvimento Econômico } \\ \text { MPOG } & \text { Ministério do } \\ \text { CGU } & \text { Controladoria-Geral da União } \\ \text { BID } & \text { Banco Interamericano de Desenvolvimento } \\ \text { ONU } & \text { Organização das Nações Unidas } \\ \text { BID } & \text { Banco Interamericano de Desenvolvimento }\end{array}$




\section{LISTA DE QUADROS}

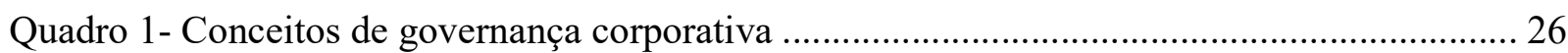

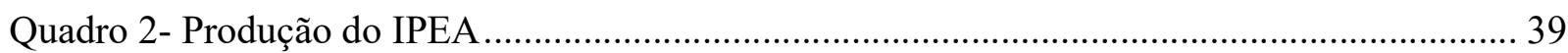

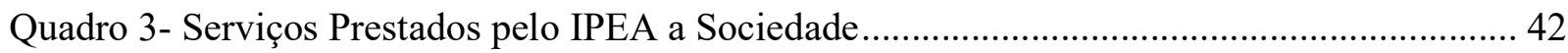

Quadro 4- Comparação das dimensões propostas pela ferramenta de avaliação SERVQUAL com as dimensões avaliadas no Plano Estratégico do IPEA 2013 - 2023 …....................................... 55

Quadro 5- Determinantes originais da qualidade ................................................................... 58

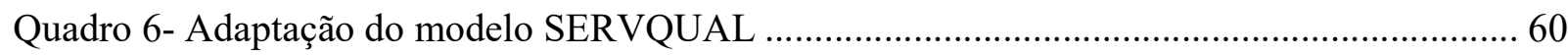

Quadro 7- Questionários respectivos à expectativa e a percepção para mensurar a Qualidade do

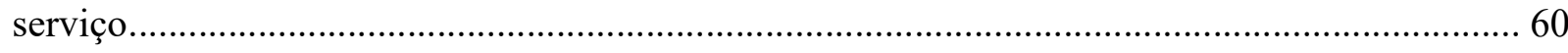

Quadro 8- Classificação da confiabilidade a partir do coeficiente de Alpha de Cronbach ........... 65

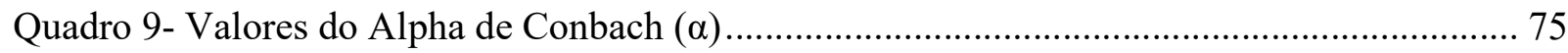

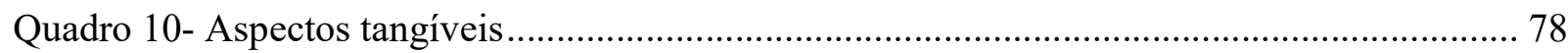

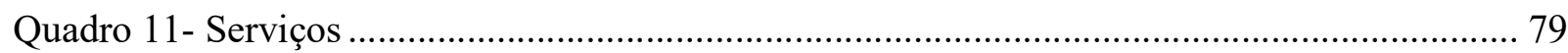

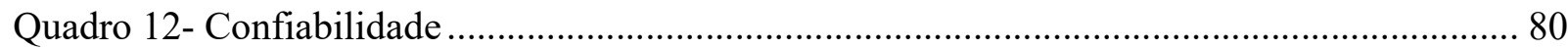

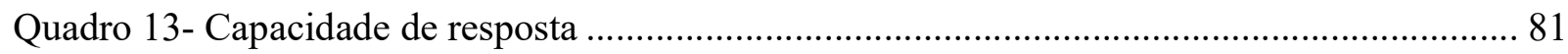

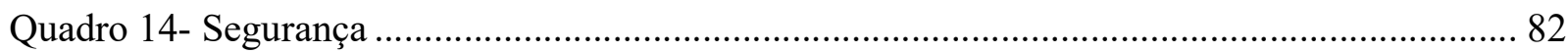

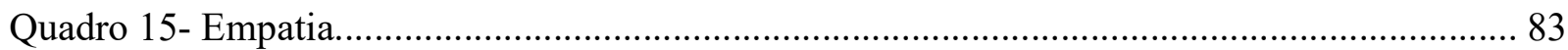




\section{LISTA DE FIGURAS}

Figura 1- Modelo do Processo Global de Responsabilidade no Setor Público ............................ 24

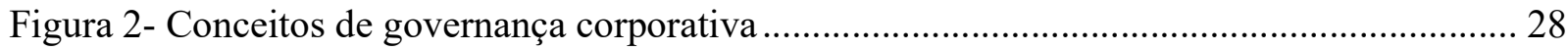

Figura 3- Sistema de Governança em Órgãos e Entidades da Administração Pública ................. 32

Figura 4- Critérios de Análise do Gespública (Brasil 2010) ........................................................ 36

Figura 5- Governança e Construção do Plano Estratégico do Ipea ............................................... 38

Figura 6- Fluxo do Processo de Planejamento do IPEA ……........................................................ 43

Figura 7- Modelo Conceitual de Qualidade em Serviço ................................................................ 56 


\section{LISTA DE GRÁFICOS}

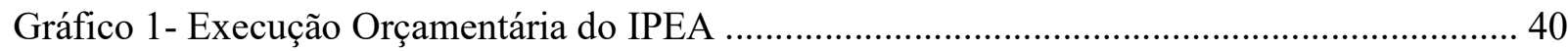

Gráfico 2- Execução Orçamentária - Custeio e Investimento do IPEA......................................... 41

Gráfico 3- Força De Trabalho de Nível Superior e Nível Intermediário........................................ 42

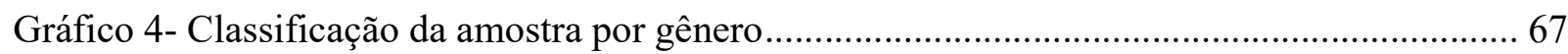

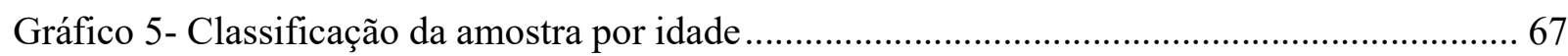

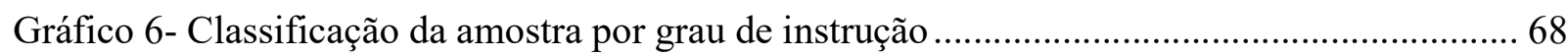

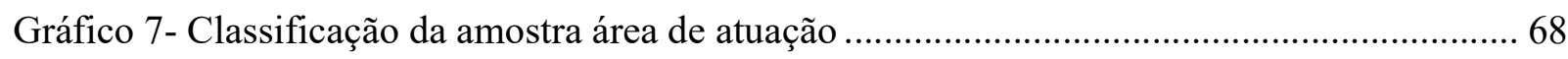

Gráfico 8- Percentual médio dos respondentes em aspectos tangíveis ....................................... 69

Gráfico 9- Percentual médio dos respondentes em serviços ...................................................... 70

Gráfico 10- Percentual médio dos respondentes em confiabilidade ........................................... 71

Gráfico 11- Percentual médio dos respondentes em capacidade de resposta............................... 72

Gráfico 12- Percentual médio dos respondentes em segurança .................................................. 73

Gráfico 13- Percentual médio dos respondentes em empatia....................................................... 74 


\section{RESUMO}

O presente trabalho tem por objetivo analisar a qualidade dos serviços prestados pelo Instituto de Pesquisa Econômica Aplicada - IPEA sob a ótica da governança corporativa aplicada ao setor público. Serve de base para esta pesquisa o Plano Estratégico 2013-2023 desenvolvido pelo IPEA com ênfase nas questões ligadas ao contexto das atividades finalísticas e de gestão diante dos desafios mostrados pela pesquisa com os atores internos e externos à instituição.

Uma instituição pública tem em seu escopo que cumprir uma função social originada e definida na sua criação. Pretende-se com isso suprir as demandas da sociedade por meio do fornecimento de serviços públicos que tenha um mínimo de qualidade necessária à satisfação das necessidades do usuário. O IPEA, como uma instituição pública de excelência, só cumpre seu papel institucional da melhor forma possível desde que compreenda as necessidades do usuário. Partindo desse princípio este trabalho busca identificar a qualidade dos serviços prestados por essa instituição, utilizando como instrumento de avaliação a Escala SERVQUAL adaptada à realidade do setor público. Nessa escala pretende-se avaliar a qualidade em duas etapas.

A primeira etapa trata de avaliação da expectativa que o usuário teria de uma instituição pública de pesquisa de excelência. E, na segunda etapa, a avaliação trata da percepção que o usuário teria dessa mesma instituição. O questionário eletrônico aplicado, com 22 afirmativas cada, divididos em 6 dimensões, foi enviado ao público interno ao IPEA para uma amostra definida em 100 usuários.

Foram adotados métodos quantitativos para avaliação dos dados. Utilizou-se como ferramenta de medição a escala SERVQUAL, desenvolvida por Parasuramam, Zeithaml e Berry (1988), e adaptada ao cenário que compõe a governança corporativa, composto por 6 dimensões (aspectos tangíveis, serviço, confiabilidade, capacidade de resposta, segurança e empatia).

PALAVRA-CHAVE: Governança Corporativa, plano estratégico, escala SERVQUAL, qualidade do serviço público. 


\begin{abstract}
The objective of this study is to analyze the quality of services provided by the Institute for Applied Economic Research - IPEA under the corporate governance perspective applied to the public sector. It is based on this research the Strategic Plan 2013-2023 developed by the IPEA with emphasis on the issues related to the context of the finalistic activities and management in the face of the challenges shown by the research with the internal and external actors of the institution.

A public institution has in its scope to fulfill a social function originated and defined in its creation. The aim is to supply the demands of society by providing public services that have a minimum of quality necessary to satisfy user needs. IPEA, as a public institution of excellence, only fulfills its institutional role in the best possible way as long as it understands the needs of the user. Based on this principle, this work seeks to identify the quality of the services provided by this institution, using as an evaluation tool the SERVQUAL Scale adapted to the reality of the public sector. This scale is intended to evaluate the quality in two stages.

The first step is about evaluating the user's expectation of a public research institution of excellence. And, in the second stage, the evaluation deals with the perception that the user would have of that same institution. The electronic questionnaire applied, with 22 statements each, divided into 6 dimensions, was sent to the internal public to the IPEA for a sample defined by 100 users.

Quantitative methods were used to evaluate the data. It was used as a measurement tool the SERVQUAL scale, developed by Parasuramam, Zeithaml and Berry (1988), and adapted to the scenario that composes corporate governance, composed of 6 dimensions (tangible aspects, service, reliability, responsiveness, empathy).
\end{abstract}

KEYWORDS: Corporate Governance, strategic plan, SERVQUAL scale, quality of public service. 


\section{Sumário}

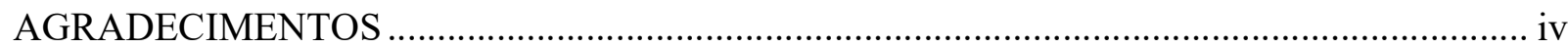

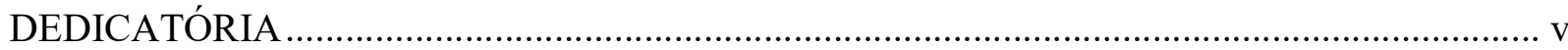

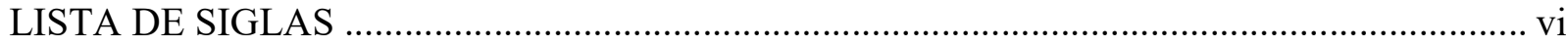

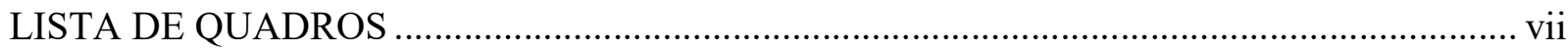

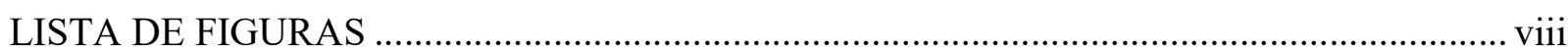

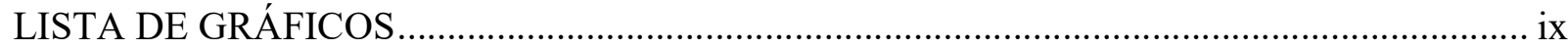

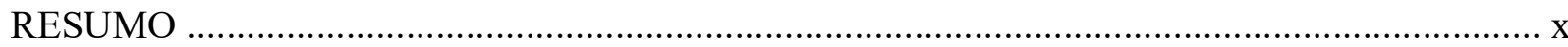

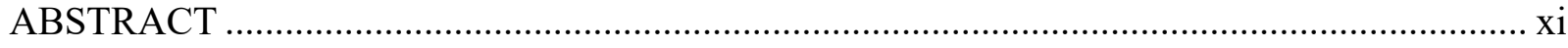

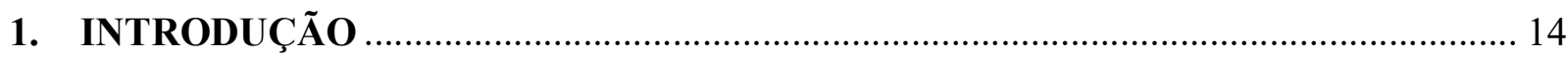

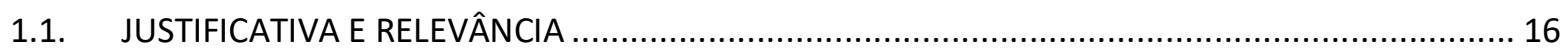

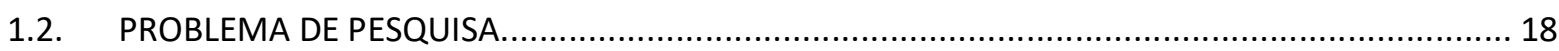

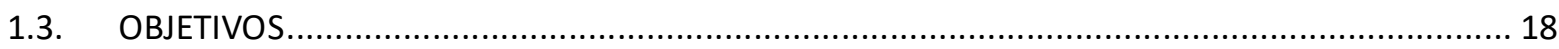

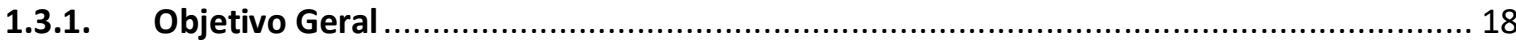

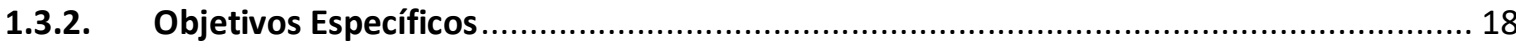

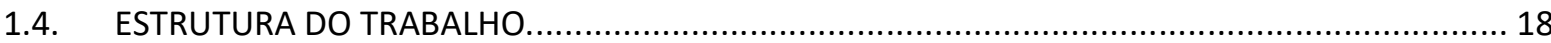

2. REVISÃO DA LITERATURA: GOVERNANÇA CORPORATIVA APLICADA AO

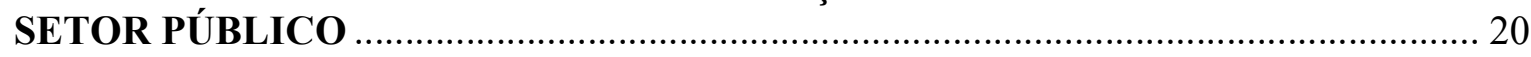

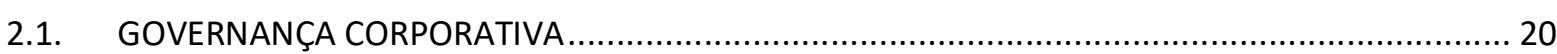

2.1.1. Teoria da Agência ............................................................. Erro! Indicador não definido.

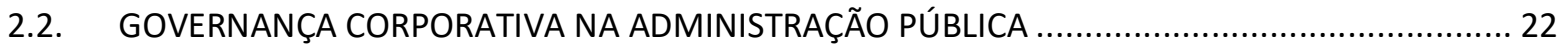

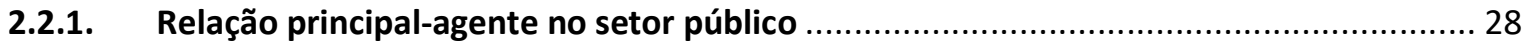

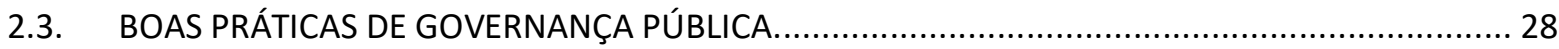

3. ESTRUTURA DE GOVERNANÇA NA ADMINISTRAÇÃO PÚBLICA ..................... 29

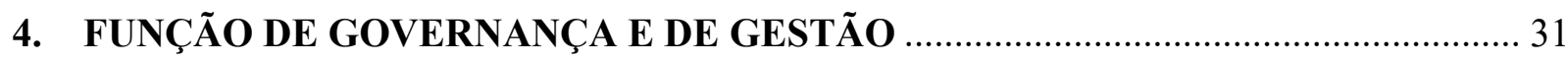

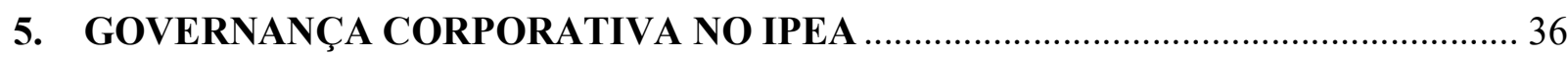

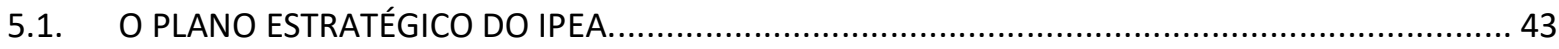

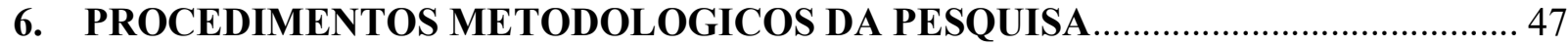

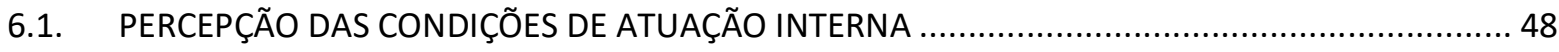

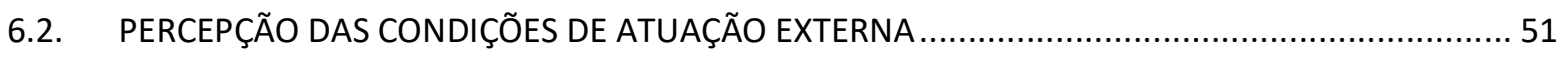

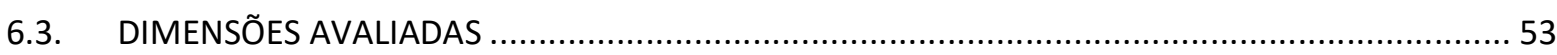

6.4. COMPARATIVO DE DIMENSÕES AVALIADAS NO IPEA E O MODELO DE AVALIAÇÃO DA

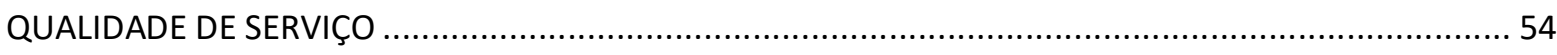

7. INSTRUMENTO DE AVALIAÇÃO DA QUALIDADE DOS SERVIÇOS.................. 55 


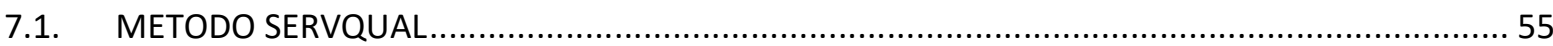

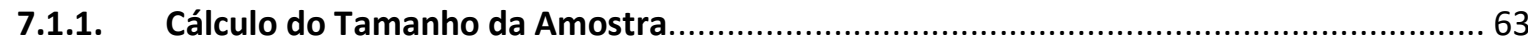

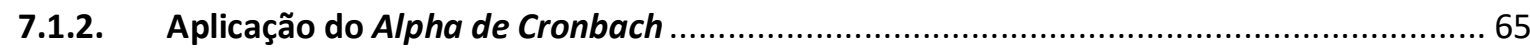

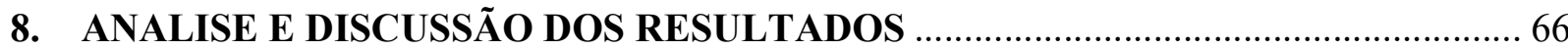

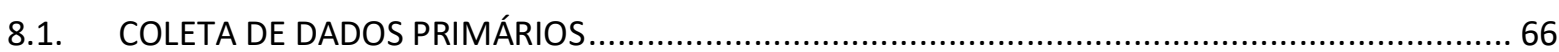

8.2. DISTRIBUIÇÃO PERCENTUAL DOS RESPONDENTES POR DIMENSÃO ….................................... 69

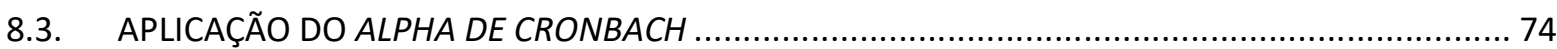

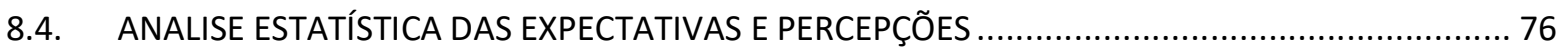

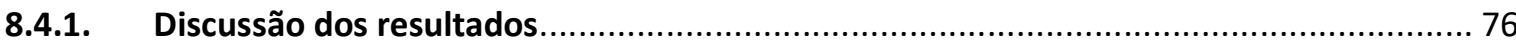

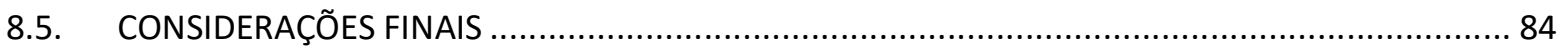

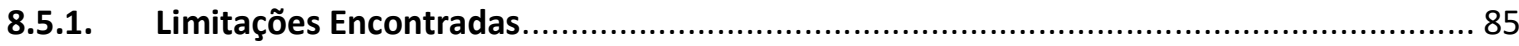

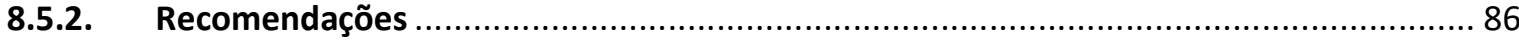

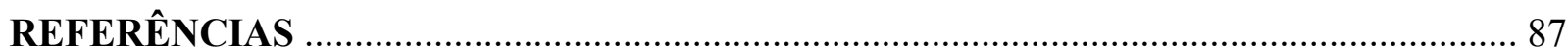

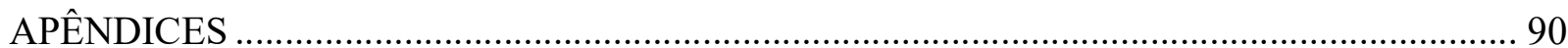




\section{INTRODUÇÃO}

O papel do Estado na sociedade é manter a ordem, a segurança, a prosperidade, o bem-estar; proteger a sociedade de agressões externas; promover a organização da economia; repartir riquezas; aplicar a justiça; garantir a saúde, a educação e a renda do povo. Em razão disso, o Estado se organiza de forma a atender as demandas da sociedade, mantendo o estado de bem-estar preconizado pela Constituição Federal Brasileira. Deste ponto de vista este trabalho pretende analisar a qualidade da prestação de serviço no Instituto de Pesquisa Econômica Aplicada - IPEA, como instituição pública de pesquisa de excelência, sob a ótica da governança corporativa.

Antes, porém, devemos conhecer um pouco mais sobre o que é governança corporativa. Na origem da expressão governança, "era utilizada para referir-se a políticas de desenvolvimento que se orientavam por determinados pressupostos sobre elementos estruturais como gestão, responsabilidades, transparência e legalidade do setor público, considerados necessários ao desenvolvimento de todas as sociedades" (MATIAS-PEREIRA, 2010) apud (OECD, 2001).

Governança corporativa corresponde aos processos, costumes, políticas, leis e instituições que são usados para fazer a administração de uma empresa privada e que também é usada nas instituições públicas. Os princípios da Governança Corporativa aplicada a administração pública é composta por seis passos fundamentais (BENEDICTO; RODRIGUES; ABBUD, 2008. P: 11, 12) apud (Mello, 2006 e Marques, 2007): liderança, compromisso, integridade, Responsabilidade/prestação de contas, transparência, integração.

Para enfrentar os conflitos de agencia as instituições públicas e privadas se viram obrigadas a reestruturarem seus processos organizacionais com base nos princípios da Governança Corporativa de modo a fazer frente a evolução da sociedade e suas demandas crescente por serviços de qualidade. A linha de ação definida por (BENEDICTO; RODRIGUES; ABBUD, 2008) contribui com a definição de um modelo de gestão mais eficiente, a exemplo de: “(i) ação executiva - envolvimento em decisões executivas cruciais; (ii) direção - formulação da direção estratégica para o futuro da organização a longo prazo;

(iii) supervisão - monitoração e vigilância da performance da gerência, e; (iv) accountability 
- reconhecimento das responsabilidades daqueles que legitimamente procuram pela responsabilidade". O que se busca nesse caso tem a ver com a clareza das informações relativas aos papeis de cada ator envolvido onde a administração pública exige de seus agentes a adoção de novas práticas de gestão e de prestação de contas à sociedade, demonstrando seu grau de comprometimento.

Governança Corporativa aplicada ao setor público, requer, segundo (Marques, 2007): (i) uma clara identificação e articulação das definições de responsabilidade; (ii) uma compreensão real das relações existentes entre os stakeholders (partes interessadas) da organização e outros interesses para controlar os seus recursos e dividir resultados; e (iii) sustentação da gestão, particularmente do nível superior. No caso especifico do setor público, este trabalho dará uma atenção especial ao conjunto de ações que envolvem a implantação do Plano Estratégico 2013-2023 do Instituto de Pesquisa Econômica Aplicada e sua eficiência e eficácia na gestão.

A literatura narra que a Governança corporativa é uma resposta à antiga administração centralizadora e autoritária, que ignorava totalmente os colaboradores da instituição, os sócios, os acionistas, tendo como principal objetivo agradar a um controlador majoritário. No caso do setor público, não havia um foco especifico na sociedade. O modelo centralizador perdeu força e deu lugar a um modelo em que a Comissão de Valores Mobiliários (CVM $)^{1} \mathrm{a}$ define como "um conjunto de práticas que tem por finalidade otimizar o desempenho de uma companhia ao proteger todas as partes interessadas, tais como investidores, empregados e credores, facilitando o acesso ao capital". Busca-se extrair dessa perspectiva de que a Governança Corporativa tenha como papel principal ao gerenciar de forma organizada uma instituição onde se pretende diminuir os conflitos de interesse por meio da participação de todos os atores envolvidos objetivando melhores resultados.

Fatores relevantes têm contribuído para o interesse do mercado pelas questões ligadas ao estudo das melhores práticas da governança corporativa em razão de escândalos de corrupção ocorridos nas grandes corporações mundiais. Outros fatos importantes contribuem

\footnotetext{
${ }^{1}$ (CATAPAN; CHEROBIM, 2010). Em 2001, a Bovespa criou o Índice de Governança Corporativa (IGC). Seu principal objetivo é medir o desempenho de uma carteira composta por ações de empresas que apresentem bons níveis de governança.
} 
para o avanço do interesse pelo estudo da governança corporativa tem a ver com as privatizações, fusões e aquisições, e mais (ALMEIDA et al., 2010):

(...) o crescimento dos fundos de pensão também contribuiu para a preocupação com os estudos da governança das corporações. Todo esse processo tem impactado e promovido mudanças nas legislações dos diversos países, os quais têm buscado estabelecer regras mais claras e transparentes como forma de garantir maior proteção aos investidores e criar ambiente favorável ao alinhamento de interesses.

A mensuração adequada das atividades estatais necessita levar em conta o equilíbrio entre os poderes constituídos conforme preconiza a Constituição Federal de 1988. O propósito das diretrizes da boa governança aplicada ao setor público é fazer o trabalho de aproximação com base nos termos de "balanceamento de poder e autoridade, onde se sugere que deva evitar a concentração de poder, autoridade e responsabilidade nas mãos de um ou de poucos indivíduos" e as "definições dos papeis e responsabilidade das instâncias de governança, tendo como foco a atribuição de responsabilidades aos membros, executivos e não executivos, da cúpula da organização" (TCU, 2011).

Como podemos observar o contexto exposto acima, o tema está inserido em uma vasta gama de possibilidade de discussões e sistematizações. Esta pesquisa se utilizará de alguns dados da pesquisa interna do IPEA, que apontou os resultados da implantação do Plano Estratégico 2013 - 2023, para avaliar a qualidade dos serviços prestados à sociedade sob a ótica da governança corporativa.

\subsection{JUSTIFICATIVA E RELEVÂNCIA}

A Governança Corporativa aplicada ao setor público no Brasil ainda é pouco difundida como instrumento de monitoramento e controle de suas atividades. A literatura aponta para ações pontuais de controle que não dão uma visão mais ampla da situação administrativa das entidades públicas. Dentro das atribuições de supervisão da gestão é fundamental fazer um paralelo de informações relativas à execução orçamentaria, qualidade e quantidade de mão-de-obra, estrutura física e a qualidade da prestação de serviço à sociedade. 
Esta pesquisa pretende aproveitar essa lacuna e tratar do princípio da boa governança para avaliar a qualidade dos serviços prestados pelo IPEA à sociedade por meio do instrumento de mensuração de qualidade SERVQUAL ${ }^{2}$ de modo a subsidiar discussões em todos os níveis hierárquicos, servindo de ferramenta para o enfretamento dos desafios diante das regras atuais de governança e possíveis mudanças com o passar dos tempos.

Não se pretende discutir aqui o arcabouço normativo nem o conteúdo da produção do conhecimento do IPEA. A proposta é discutir e apresentar a importância dos princípios da boa governança aos diversos níveis hierárquicos de modo a dar dinamismo, clareza e eficiência, contribuindo, com isso, para melhoria das atividades da instituição como um todo.

A relevância desta proposta de estudo está na possibilidade de se discutir à luz da governança corporativa aplicada ao setor público os pontos vulneráveis da estrutura organizacional do IPEA a serem constatados na avaliação da amostra, tendo como objetivo claro a correção de rumo com base nos critérios estabelecidos no Plano Estratégico 2013 - 2023.

Como instituição pública de pesquisa e com uma gama enorme de temas a serem pesquisados, o IPEA precisa se relacionar com diversos atores internos e externos. Logicamente que essa situação requer um trabalho enorme de coordenação entre a presidência da instituição e das diretorias com outros órgãos públicos, entidades particulares e, até mesmo, com a sociedade.

\footnotetext{
${ }^{2}$ ESCALA SERVQUAL: é o nome do instrumento de mensuração da Qualidade Percebida criado por três pesquisadores norte-americanos de marketing, Parasuraman, Zeithaml e Berry em 1988. Essa escala resultou da continuidade que deram à sua pesquisa acerca dos cinco tipos de gaps que afetam o nível de qualidade em serviços entregue ao consumidor final. Para estes pesquisadores, a qualidade em serviços pode ser afetada por cinco tipos de discrepâncias (lacunas ou gaps), a saber: O primeiro gap trata da discrepância entre as expectativas do consumidor e a percepção das expectativas por parte dos gerentes. $\mathrm{O}$ segundo gap refere-se à lacuna existente entre a percepção dos gerentes sobre as expectativas dos usuários e os padrões de qualidade da empresa. O gap 3 origina-se na lacuna entre as normas de qualidade e o serviço efetivamente entregue ao usuário e o gap 4 é a diferença entre o serviço prometido e o serviço prestado. Enquanto o quarto gap trata da comunicação com o mercado ao projetar o nível de qualidade do serviço a ser prestado, o quinto gap corresponde à qualidade percebida do serviço; ou seja, é a discrepância entre o serviço prestado e o serviço recebido. Fonte: https://pt.wikipedia.org/wiki/Escala_servqual.
} 


\subsection{PROBLEMA DE PESQUISA}

Com base nos princípios definidos pela regra de governança no setor público - comentados mais adiante - esta pesquisa tenta responder às questões relacionadas a estrutura de governança corporativa implantadas no Instituto de Pesquisa Econômica Aplicada - IPEA, tomando como base o Plano Estratégico 2013-2023.

Para efeito desta pesquisa a questão chave é identificar os fatores de gestão que contribuem para a falta de qualidade na prestação de serviços públicos a sociedade.

\subsection{OBJETIVOS}

Serão apresentados o objetivo geral e os objetivos específicos, considerando a linha de raciocínio do tema proposto.

\subsubsection{Objetivo Geral}

Avaliar a qualidade dos serviços prestados pelo IPEA à sociedade por meio da escala SERVQUAL tendo em conta os princípios da governança corporativa aplicada ao setor público.

\subsubsection{Objetivos Específicos}

Analisar de forma crítica a qualidade dos serviços prestados pelo IPEA à sociedade de modo a colaborar para uma atuação mais eficiente naquilo que mais dificulta o desenvolvimento da atividade institucional dentro das cinco dimensões de avaliação da escala SERVQUAL.

\subsection{ESTRUTURA DO TRABALHO}

Esta pesquisa está distribuída em oito capítulos conforme relacionado abaixo:

- Capitulo 1 apresenta a introdução ao tema do estudo com fazendo um apanhado geral sobre governança corporativa aplicada ao setor público. 
Na sequência apresentamos a justificativa e relevância, os problemas de pesquisa, o objetivo geral e os objetivos específicos.

- Capítulo 2 apresenta a revisão da literatura que embasa a pesquisa realizada de modo permitir o exame das diferentes dimensões e conceito de governança corporativa passíveis de serem aplicadas na administração pública, à luz de estudos teóricos e práticos presentes na literatura estudada. Os assuntos estudados neste capítulo foram divididos em três seções. Na Seção 2.1, buscamos identificar os conceitos de governança corporativa passíveis de serem aplicados à implantação de planos estratégicos e políticas públicas com propósitos de buscar a eficiência na gestão do setor público. Em seguida, na Seção 2.2, buscamos identificar os conceitos de governança corporativa aplicadas especificamente ao setor público e suas diferenças com o setor privado: apesar da semelhança nos propósitos da governança corporativa, o setor público apresenta alguns diferenciais que precisam de maiores critérios no uso dos conceitos de governança como instrumento de gestão. Na seção 2.3, buscamos o significado das boas práticas de governança.

- Capítulo 3 apresenta a estrutura atual que trata de governança corporativa dentro do Governo Federal, onde se busca compreender a conduta da alta administração para com o tema e os desafios da implantação.

- Capítulo 4 apresenta as funções de governança e de gestão, onde se busca definir o direcionamento estratégico; implementar programas, como funções de governança e avaliar o ambiente; direcionar e orientar; monitorar como funções de gestão.

- Capítulo 5 apresenta a governança no IPEA, onde se pretende analisar ações que compõem o contexto para entendimento do processo de produção e sua evolução dentro do prazo estudado, comparados com a 
execução orçamentaria de custeio e investimento e a situação de sua força de trabalho.

- Capítulo 6 apresenta os procedimentos metodológicos da pesquisa com vistas a mostrar a percepção das condições de atuação interna e externa da instituição onde se busca compreender o clima organizacional e os desafios a serem enfrentados. Os principais desafios mais importantes foram definidos em 7 dimensões ligadas a organizacional: planejamento; e processo decisório; corpo técnico e administrativo; infraestrutura física e tecnológica; gestão e disseminação do conhecimento; imagem e comunicação; estudos e pesquisa; base de dados e seminários.

- Capítulo 7 apresenta o instrumento de avaliação SERVQUAL o qual utilizaremos na sistematização dos dados da pesquisa de amostral feita com os usuários internos do IPEA. Antes, porém, apresentamos o modelo conceitual do instrumento com vistas ao conhecimento das determinantes que servem de base para a sistematização da pesquisa.

- Capítulo 8 apresenta a discussão do resultado da pesquisa sistematizada por meio do Software SPSS, onde se avalia o perfil da amostra, o percentual de repostas em cada dimensão, a verificação o índice de confiança no resultado amostra, analise estatística sobre as expectativas e percepções e discussão dos resultados. No mesmo capítulo apresentamos as considerações finais.

\section{REVISÃO DA LITERATURA: GOVERNANÇA CORPORATIVA APLICADA AO SETOR PÚBLICO}

2.1. GOVERNANÇA CORPORATIVA 
A governança corporativa pode ser definida genericamente como mecanismos ou princípios que governam o processo decisório. Também é considerada um conjunto de regras que visam minimizar os problemas de agencia ${ }^{3}$.

Marques (2007) cita que a "governança corporativa foi se desenvolvendo através de diferentes vias e um dos principais promotores do tema foi a OCDE que construiu os princípios, permitindo que estabelecem os seus pilares fundamentais":

a) Os direitos dos acionistas;

b) O tratamento equitativo dos acionistas;

c) O papel dos terceiros fornecedores de recursos;

d) Acesso e transparência da informação;

e) A responsabilidade da diretoria e do conselho de administração.

O tema está calcado em três preceitos basilares definidos como: transparência, integridade e accountability (responsabilidade por prestar contas). Instituição como IBGC tem dado contribuições e estímulos nas últimas décadas para fomentar a aplicação da governança corporativa no setor privado e no setor público, nos níveis mundial e nacional. O IBGC conceitua que governança corporativa aplicada às empresas é:

(...) o sistema que permite aos acionistas ou cotistas o governo estratégico de sua empresa e a efetiva monitoração da direção executiva. As ferramentas que garantem o controle da propriedade sobre a gestão são o Conselho de Administração, a Auditoria Independente e o Conselho Fiscal. As boas práticas de governança corporativa têm a finalidade de aumentar o valor da sociedade, facilitar seu acesso ao capital e contribuir para a sua perenidade. (MACHADO, 2011, apud IBGC).

Ausência de conselheiros qualificados e de bons sistemas de governança corporativa tem levado empresas ao fracasso decorrente de: (i) abusos de poder (do acionista controlador sobre minoritários, da diretoria sobre o acionista e dos administradores sobre terceiros); (ii) erros estratégicos (resultado de muito poder

\footnotetext{
${ }^{3}$ A teoria da agência visa a analisar os conflitos e custos resultantes da separação entre a propriedade e o controle de capital, o que origina as assimetrias informacionais, os riscos e outros problemas pertinentes à relação principal-agente (JENSEN E MECKLING, 1976)
} 
concentrado no executivo principal); (iii) fraudes (uso de informação privilegiada em benefício próprio, atuação em conflito de interesses), (MELLO, 2006; IBGC, 2008). (ROSSONI; MACHADO-DA-SILVA, 2010) apud (CVM, IBGC e OCDE).

\subsection{GOVERNANÇA CORPORATIVA NA ADMINISTRAÇÃO PÚBLICA}

Há diferenças entre a governança no setor privado e a governança no setor público. Barret (2001 afirma que, apesar de haver similaridades, é importante reconhecer as diferenças básicas entre estruturas administrativas das entidades do setor público e do setor privado, bem como entre seus frameworks de responsabilização (accountability). O ambiente político, com foco em verificações, contabilidade e sistema de valores que enfatizam questões éticas e códigos de conduta, implica um framework de Governança Corporativa completamente diferente daquele orientado a negócios, típico do setor privado.

Para o IFAC, 2001 (p. 1), o foco da governança no setor privado é o Conselho de Administração. Já no setor público, algumas vezes, é difícil identificar e definir essa entidade diretiva, pois as organizações operam sob diferentes estatutos e frameworks gerenciais. Diferentemente do setor privado, onde deve prestar contas aos sócios e clientes, no setor público os gestores estão sujeitos a diversos mecanismos de controle, devendo prestar contas a vários stakeholders, tais como: Ministros, outros órgãos de governo, o Parlamento, cidadãos, clientes e o público em geral, cada um com seu legítimo interesse, mas não necessariamente com qualquer direito de propriedade.

Marques (2007) corrobora esse entendimento ao afirmar que o setor público tem responsabilidades "accountabilities" perante numerosos e variados stakeholders, além das mais diversas exigências sobre abertura e transparência das informações. O termo Governança Corporativa é indissoluvelmente unido com accountability (responsabilidade por prestar contas), por isso ter sido trazido do setor privado. Assim, a diferença entre as organizações depende da natureza da entidade envolvida e das exigências de prestação de contas a que são submetidas. 
O setor privado utiliza a Governança Corporativa para ser competitivo e entregar bons resultados regularmente, enquanto a utilização da Governança Corporativa no setor público é vantajosa por agregar um conjunto de processos que asseguram a "accountability” dentro das organizações públicas (MARQUES, 2007). Assim, a diferença da Governança Corporativa no setor público e privado não seria conceitual, mas estaria embutida na finalidade da adoção das boas práticas inerentes ao conceito. $\mathrm{O}$ objetivo no setor privado estaria na busca pelo resultado, e no setor público, a busca pela conformidade.

Branco (2013) narra que o sistema de governança corporativa deve ser norteado por quatro princípios, que são totalmente aplicáveis ao setor público, a saber:

a) Transparência: quanto mais informação estiver disponível aos cidadãos, maior será a capacidade dos cidadãos de controlar a instituição pública para que cumpra seu papel e não sucumba a interesses privados. Portanto, a instituição pública deve querer divulgar as informações, exceto aquelas justificadamente de natureza reservada ou sigilosa;

b) Equidade: nenhum dos interessados na instituição pública deve ser privilegiado em relação aos outros por causa de interesses espúrios;

c) Prestação de contas: a instituição pública deve continuamente prestar contas de sua atuação e dos resultados alcançados aos interessados, especialmente aos cidadãos;

d) Responsabilidade corporativa (institucional): a alta administração deve estar comprometida com a sustentabilidade das instituições públicas, visando sua longevidade, o que inclui também considerações de ordem social e ambiental na definição dos negócios e operações.

Governança no setor público compreende essencialmente os mecanismos de liderança, estratégia e controle postos em prática para avaliar, direcionar e monitorar a atuação da gestão, com vistas à condução de políticas públicas e à prestação de serviços de interesse da sociedade.

A base para o entendimento das atividades institucionais dentro do contexto da atividade pública foi definida na figura 1 como modelo global de 
responsabilidade. Nele deve ser observada a importância da responsabilidade social para o desempenho institucional com abrangência nos três poderes.

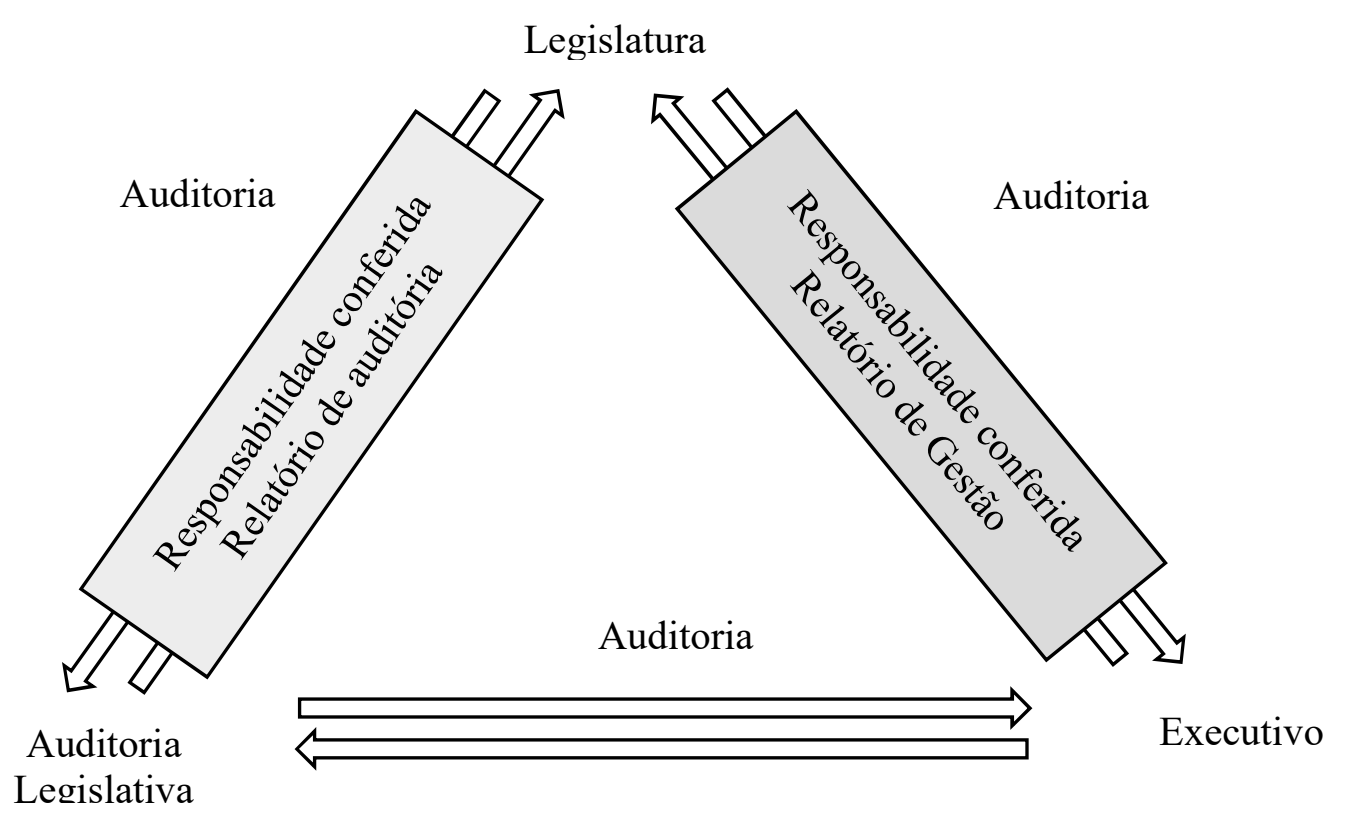

Fonte: Adaptado de International Federation of Accountants - IFAC (2001)

Em sua conceituação mais ampla (Monteiro (2015) narra que os agentes de governança corporativa são membros dos conselhos de administração que devem ser adotados em todos os tipos de organização.

Na mesma citação, Marques (2007) enfatiza que no setor público a aplicação das práticas de governança corporativa envolvem alguns aspectos importantes como: (1) separação das funções do diretor, executivo e administradores; (2) um conselho que tenha a maioria de diretores qualificados para o exercício da função de conselheiro; (3) criação de um comitê de auditoria com membros externos com proteção da independência dos auditores; (4) relatórios financeiros padronizados que facilitem o entendimento; (5) aplicação de códigos de ética da entidade. 
Diante das atribuições dos agentes da Governança Corporativa e dos elementos para o sucesso desta no contexto das organizações públicas pode-se categorizá-los da seguinte forma, na citação de (MONTEIRO; HAMMES, 2015):

a) Governo: o governo deve exercer o papel de Diretoria Executiva, atuando como um dos proprietários informado, proativo e transformador adotando uma política de gestão transparente e imparcial, certificando-se que as práticas de governança corporativa sejam coordenadas e aplicadas com responsabilidade, fiscalização, constante avaliação e com alto grau de profissionalismo e eficácia, respeitando os direitos e opiniões das demais partes interessadas (stakeholders), dentre eles a sociedade que representa.

b) Sociedade (sócios): à sociedade competiria o papel dos acionistas ou sócios como aqueles interessados em saber como seu capital social, que se materializa pelos impostos pagos é aplicado. A sociedade enfim deve acompanhar cotidianamente como os recursos públicos são geridos.

c) Administradores: no contexto público são os gestores, eleitos ou em exercício de cargo, ou função pública, com responsabilidade de gerir os recursos e bens públicos, prestar contas ao governo, demais conselhos e a sociedade beneficiando-a com serviços de qualidade;

d) Conselhos comunitários: eleitos em assembleia geral pelo governo, administradores e representantes da sociedade, tendo como características principais experiência e qualificação exercendo o papel de Conselho Fiscal ou Conselho da Administração na fiscalização da gestão, por meio da participação em Conselhos, tais como Conselhos Municipais de Saúde, Educação e Segurança Pública e demais esferas e fórum de participação e representação social;

e) Comitês de auditoria: são os órgãos de controle existentes nas mais diferentes esferas, que devem exercer o controle prévio, concomitante de subsequente. Papel que deve ser exercido pelos Tribunais de Contas Municipais, Estaduais e da União e pelos órgãos de controle interno de cada Poder. $\mathrm{O}$ acompanhamento e exercício do controle externo e interno é uma forma de possibilitar uma constante melhora no desempenho da administração, pois através de auditorias e pareceres técnicos é possível a correção de erros e também tornar os relatórios financeiros mais transparentes, para que possam atingir as expectativas e obrigações de accountability. 
O que se busca com a aplicação da governança corporativa na administração pública é a eficiência na prestação de serviços à sociedade. Isso, no entanto, requer atitudes proativas dentro dos preceitos morais e éticos previstos nos pilares da governança corporativa. Para fins de compreensão do tema dentro desta pesquisa observa-se os conceitos e principais características elaboradas pelos diversos autores apresentados no quadro 1.

Quadro 1- conceitos de governança corporativa

\begin{tabular}{|c|c|c|}
\hline Autor & Conceito & Principais Características \\
\hline $\begin{array}{l}\text { Shleifer; Vishny } \\
(1996, \text { p. 2) }\end{array}$ & $\begin{array}{l}\text { Governança corporativa é o campo da } \\
\text { administração que trata do conjunto de } \\
\text { relações entre a direção das empresas, } \\
\text { seus conselhos de administração, seus } \\
\text { acionistas e outras partes interessadas. } \\
\text { Estabelece os caminhos pelos quais os } \\
\text { provedores de capital das corporações são } \\
\text { assegurados do retorno de seus } \\
\text { investimentos. }\end{array}$ & $\begin{array}{l}\text { Objetivo: Assegurar o retorno para os } \\
\text { investidores das organizações } \\
\text { (Valor). } \\
\text { Qualificação: Consiste em } \\
\text { mecanismos que tratam das relações } \\
\text { entre a direção, conselhos, acionistas } \\
\text { e interessados (Mecanismo de } \\
\text { relacionamento). }\end{array}$ \\
\hline $\begin{array}{l}\text { Cadbury (1999, p. } \\
\text { 1) }\end{array}$ & $\begin{array}{l}\text { Governança corporativa é o sistema por } \\
\text { meio do qual as companhias são dirigidas } \\
\text { e controladas. É expressa por um sistema } \\
\text { de valores que rege as organizações em } \\
\text { sua rede de relações internas e externas. }\end{array}$ & $\begin{array}{l}\text { Objetivo: Dirigir e controlar } \\
\text { corporações (Direção e controle). } \\
\text { Qualificação: É expressa em sistema } \\
\text { de valores que rege as relações } \\
\text { internas e externas (mecanismo de } \\
\text { relacionamento). }\end{array}$ \\
\hline $\begin{array}{l}\text { Claessens; } \quad \text { Fan } \\
(2000 \quad \text { apud } \\
\text { Andrade; } \\
\text { Rossetti, 2004, p. } \\
26\end{array}$ & $\begin{array}{l}\text { Governança corporativa diz respeito a } \\
\text { padrões de comportamento que } \\
\text { conduzem à eficiência, ao crescimento e } \\
\text { ao tratamento dado aos acionistas e a } \\
\text { outras partes interessadas, tendo por base } \\
\text { princípios definidos pela ética aplicada à } \\
\text { gestão de negócios. }\end{array}$ & $\begin{array}{l}\text { Objetivo: Obtenção de eficiência, } \\
\text { crescimento e bom tratamento a } \\
\text { acionistas e interessados (Indefinido). } \\
\text { Qualificação: Consiste em padrões de } \\
\text { comportamento baseados em } \\
\text { princípios ligados à ética aplicada à } \\
\text { gestão (Mecanismo } \\
\text { relacionamento). }\end{array}$ \\
\hline $\begin{array}{l}\text { Hitt; Ireland; } \\
\text { Hoskisson (2001, } \\
\text { apud Andrade; } \\
\text { Rossetti, 2004, p. } \\
\text { 26). }\end{array}$ & $\begin{array}{l}\text { Como a governança corporativa nasceu } \\
\text { entre a propriedade e a gestão das } \\
\text { empresas, seu foco é a definição de uma } \\
\text { estrutura de governo que maximize a } \\
\text { relação entre o retorno dos acionistas e os } \\
\text { benefícios auferidos pelos executivos. } \\
\text { Neste sentido, envolve a estratégia das } \\
\text { corporações, as operações, a geração de } \\
\text { valor e a destinação de resultados. }\end{array}$ & $\begin{array}{l}\text { Objetivo: Estabelecer uma estrutura } \\
\text { de governo que maximize o retorno } \\
\text { dos acionistas e os benefícios } \\
\text { auferidos pelos executivos (Valor). } \\
\text { Qualificação: Envolve a estratégia } \\
\text { das corporações, as operações, } \\
\text { geração de valor e destinação de } \\
\text { resultados (Mecanismo de } \\
\text { relacionamento). }\end{array}$ \\
\hline $\begin{array}{l}\text { Mathiesen (2002 } \\
\text { apud Andrade; }\end{array}$ & $\begin{array}{l}\text { Governança corporativa é um campo de } \\
\text { investigação focado em como monitorar } \\
\text { as corporações, através de mecanismos }\end{array}$ & $\begin{array}{l}\text { Objetivo: Gerenciamento eficaz das } \\
\text { organizações, avaliado por uma taxa } \\
\text { competitiva de retorno (Valor). }\end{array}$ \\
\hline
\end{tabular}




\begin{tabular}{|c|c|c|}
\hline $\begin{array}{l}\text { Rossetti, 2004, p. } \\
\text { 26) }\end{array}$ & $\begin{array}{l}\text { normativos, definidos em estatutos } \\
\text { legais, termos contratuais e estruturas } \\
\text { organizacionais que conduzam ao } \\
\text { gerenciamento eficaz das organizações, } \\
\text { traduzido por uma taxa competitiva de } \\
\text { retorno. }\end{array}$ & 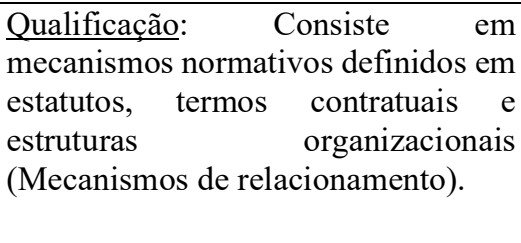 \\
\hline ITGI $(2003$, p. 6) & $\begin{array}{l}\text { Governança corporativa é um conjunto de } \\
\text { responsabilidades e de práticas exercidas } \\
\text { pelo conselho e direção executiva com o } \\
\text { objetivo de fornecer orientação } \\
\text { estratégica, garantindo que os objetivos } \\
\text { sejam atingidos, apurando que os riscos } \\
\text { sejam geridos adequadamente e } \\
\text { verificando que os recursos da empresa } \\
\text { são utilizados de modo responsável. }\end{array}$ & $\begin{array}{l}\text { Objetivo: Fornecer orientação } \\
\text { estratégica, garantir atendimento de } \\
\text { objetivos, apurar que os riscos } \\
\text { estejam geridos e verificar a } \\
\text { utilização responsável dos recursos } \\
\text { empresariais (Direção e controle). } \\
\text { Qualificação: Consiste no conjunto de } \\
\text { responsabilidades e práticas } \\
\text { (Mecanismo de relacionamento). }\end{array}$ \\
\hline $\begin{array}{l}\text { OCDE (2004, p. } \\
11)\end{array}$ & $\begin{array}{l}\text { Governança corporativa envolve um } \\
\text { conjunto de relações entre a gestão da } \\
\text { empresa, o seu órgão de administração, } \\
\text { os seus acionistas e outros interessados. } \\
\text { Estabelece, ainda, a estrutura através da } \\
\text { qual são fixados os objetivos da empresa } \\
\text { e são determinados e controlados os } \\
\text { meios para alcançar esses objetivos. }\end{array}$ & $\begin{array}{l}\text { Objetivo: Estabelecer objetivos para } \\
\text { empresa e criar mecanismos de } \\
\text { controle para atingi-los (Direção e } \\
\text { controle). } \\
\text { Qualificação: Envolve a relação entre } \\
\text { a gestão da empresa, seu órgão de } \\
\begin{array}{l}\text { administração, os acionistas e } \\
\text { interessados (Mecanismo de } \\
\text { relacionamento). }\end{array}\end{array}$ \\
\hline IBGC (2004, p. 6) & $\begin{array}{l}\text { Governança corporativa é o sistema pelo } \\
\text { qual as sociedades são dirigidas e } \\
\text { monitoradas, envolvendo os } \\
\text { relacionamentos entre acionistas/cotistas, } \\
\text { conselho de administração, diretoria, } \\
\text { auditoria independente e conselho fiscal. } \\
\text { As boas práticas de Governança } \\
\text { Corporativa têm a finalidade de aumentar } \\
\text { o valor da sociedade, facilitar seu acesso } \\
\text { ao capital e contribuir para sua } \\
\text { perenidade. }\end{array}$ & $\begin{array}{l}\text { Objetivo: Aumentar o valor da } \\
\text { empresa, facilitar a entrada de capital } \\
\text { e contribuir para sua perenidade } \\
\text { (Valor). } \\
\text { Qualificação: Consiste num sistema } \\
\text { pelo qual as sociedades são dirigidas } \\
\text { e monitoradas (Mecanismo de } \\
\text { relacionamento). }\end{array}$ \\
\hline $\begin{array}{l}\text { Andrade e } \\
\text { Rossetti (2004, p. } \\
\text { 26) }\end{array}$ & $\begin{array}{l}\text { Governança corporativa é um conjunto de } \\
\text { valores, princípios, propósitos, papéis, } \\
\text { regras e processos que regem o sistema de } \\
\text { poder e os mecanismos de gestão das } \\
\text { empresas. }\end{array}$ & $\begin{array}{l}\text { Objetivo: Gerir o sistema de poder e } \\
\text { os mecanismos de gestão das } \\
\text { empresas (Direção e controle). } \\
\text { Qualificação: Consiste num conjunto } \\
\text { de valores, princípios, propósitos, } \\
\text { papéis, regras e processos } \\
\text { (Mecanismo de relacionamento). }\end{array}$ \\
\hline $\begin{array}{l}\text { ISO/IEC } 38500 \\
(2008, \text { p. } 3)\end{array}$ & $\begin{array}{l}\text { Governança corporativa é o sistema pelo } \\
\text { qual organizações são dirigidas e } \\
\text { controladas. }\end{array}$ & $\begin{array}{l}\text { Objetivo: Dirigir e controlar } \\
\text { organizações (Direção e controle). } \\
\text { Qualificação: Consiste no sistema de } \\
\text { direção e controle (Mecanismo de } \\
\text { relacionamento). }\end{array}$ \\
\hline
\end{tabular}

Fonte: (SIMÃO, 2014, Governança Corporativa no Senado Federal, 2014) 


\subsubsection{Relação principal/agente no setor público}

Para o TCU quando se fala em governança, dois tipos básicos de atores estão envolvidos: principal e agente mostrados na figura 2. Como esses atores se manifestam no setor público?

A constituição federal de 1988 , em seu parágrafo único do artigo $1^{\circ} \mathrm{diz}$ que "Todo poder emana do povo, que o exerce por meio de seus representantes eleitos ou diretamente, nos termos desta Constituição", Infere-se que, no contexto público, a sociedade é o "principal”, pois compartilha as percepções de finalidade e valor e detêm o poder social, podendo exercê-lo de forma conjunta e ordenada por meio de estruturas criadas para representá-la, figura 2, (TCU, 2011 apud DALLARI, 2005).

Figura 2- conceitos de governança corporativa

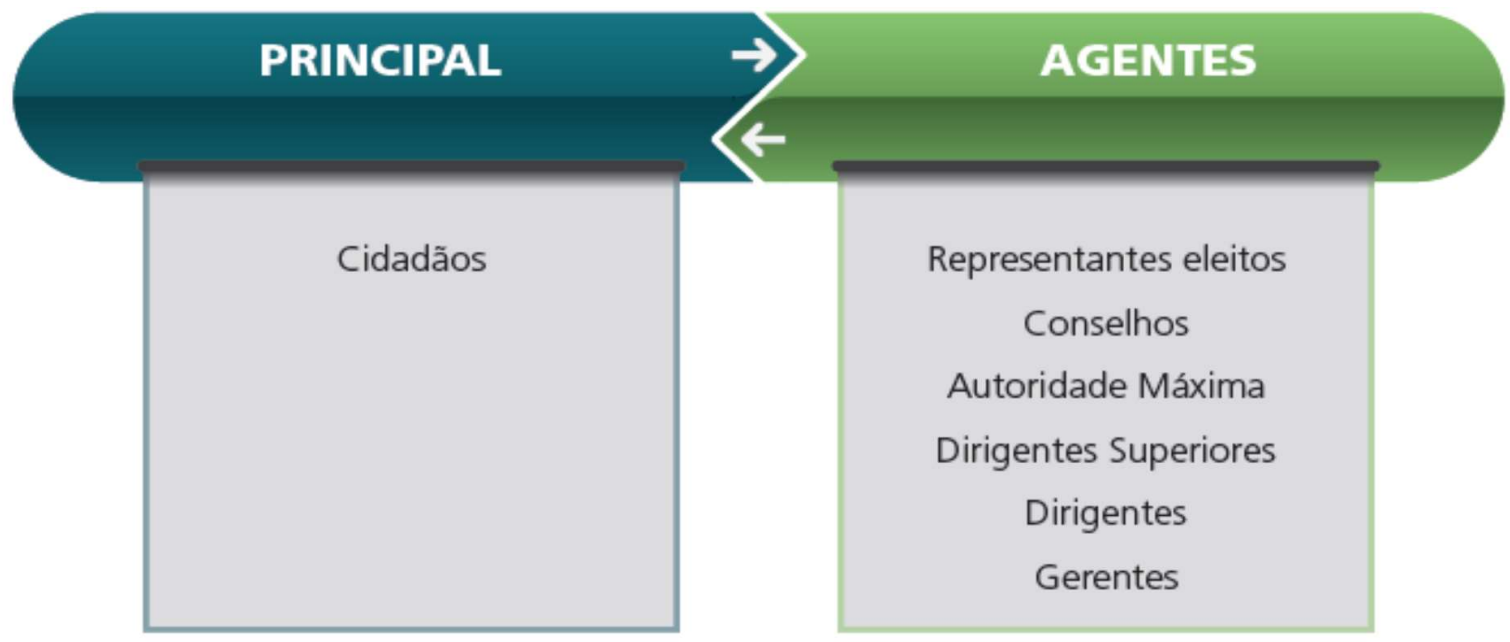

Fonte: (TCU, 2011 - Referencia básico de governança aplicavel a órgãos e entidades da administração pública e ações indutoras de melhoria)

\subsection{BOAS PRÁTICAS DE GOVERNANÇA PÚBLICA}

Para o IFAC (2013b) a boa governança no setor público permite:

a) Garantir a entrega de benefícios econômicos, sociais e ambientais para os cidadãos;

b) Garantir que a organização seja, e pareça, responsável para com os cidadãos; 
c) Ter clareza acerca de quais são os produtos e serviços efetivamente prestados para cidadãos e usuários, e manter o foco nesse propósito;

d) Ser transparente, mantendo a sociedade informada acerca das decisões tomadas e dos riscos envolvidos;

e) Possuir e utilizar informações de qualidade e mecanismos robustos de apoio às tomadas de decisão;

f) Dialogar com e prestar contas à sociedade;

g) Garantir a qualidade e a efetividade dos serviços prestados aos cidadãos;

h) Promover o desenvolvimento contínuo da liderança e dos colaboradores;

i) Definir claramente processos, papéis, responsabilidades e limites de poder e de autoridade;

j) Institucionalizar estruturas adequadas de governança;

k) Selecionar a liderança tendo por base aspectos como conhecimento, habilidades e atitudes (competências individuais);

1) Avaliar o desempenho e a conformidade da organização e da liderança, mantendo um balanceamento adequado entre eles;

m) Garantir a existência de um sistema efetivo de gestão de riscos;

n) Utilizar-se de controles internos para manter os riscos em níveis adequados e aceitáveis;

o) Controlar as finanças de forma atenta, robusta e responsável; e

p) Prover aos cidadãos dados e informações de qualidade (confiáveis, tempestivas, relevantes e compreensíveis).

Podemos também lembrar que "as boas práticas de governança corporativa convertem princípio em recomendações objetivas, alinhando interesses com a finalidade de preservar e otimizar o valor da organização", facilitando sua sobrevida em ambientes pouco favoráveis (MELLO, 2006 apud IBGC).

A questão principal é convencer a alta administração da importância dessas boas práticas de governança para a melhoria na qualidade da prestação dos serviços nas instituições públicas.

\section{ESTRUTURA DE GOVERNANÇA NA ADMINISTRAÇÃO PÚBLICA}


No ministério do Planejamento, que representa o Governo Federal na planejamento e gestão, a estrutura de governança corporativa tem pouco poder de influência nas decisões interna ou nem existem oficialmente. Unidades ou divisões com foco específico na governança corporativa dentro das instituições são pouco difundidas e quase nenhuma regulamentação. $\mathrm{O}$ que achamos de regulamentação sobre o tema está mais focado na gestão das empresas públicas. Como, por exemplo, a Comissão Interministerial de Governança Corporativa e de Administração de Participações Societárias da União - CGPAR ${ }^{4}$.

Essa Comissão Interministerial de Governança Corporativa trata de temas variados ligados a gerenciamento de risco, metas de desempenho empresarial ligadas ao planejamento estratégico das empresas públicas. Ela faz parte do plano estratégico do Ministério do Planejamento, Desenvolvimento e Gestão - MP, órgão que formula as diretrizes e define os critérios de governança corporativa das empresas estatais federais.

No documento o MP informa que orienta sua conduta de atuação de acordo com os seguintes princípios:

a) Espirito de equipe - Disposição de trabalhar em conjunto, de forma cooperativa e integrada, para que o MP cumpra suas atribuições e produza resultados de forma eficiente e eficaz;

b) Compromisso - Empenho dos colaboradores do MP em desempenhar suas funções com dedicação, responsabilidade e tempestividade;

c) Reconhecimento - Valorização dos colaboradores do MP por meio do reconhecimento da contribuição de cada um para o alcance da missão organizacional e da criação de oportunidades de desenvolvimento pessoal e profissional;

d) Excelência - Motivação do MP em buscar ser referência nos produtos, processos e serviços ofertados aos órgãos da Administração Pública Federal e aos cidadãos;

e) Cooperação - Adotar uma atitude colaborativa diante das necessidades e demandas dos órgãos da Administração Pública Federal;

\footnotetext{
${ }^{4}$ Fonte:

http://www.planejamento.gov.br/assuntos/empresas-estatais/noticias/resolucoes-aperfeicoam-papel-dogoverno-como-acionista-de-estatais
} 
f) Integridade - Guiar-se por princípios de ética e responsabilidade no trato dos bens públicos e no cumprimento das atribuições do MP;

g) Transparência - Dar à sociedade amplo acesso a informações sobre processos, procedimentos e serviços, de forma clara e tempestiva.

No IPEA a estrutura de governança corporativa ainda não saiu do papel. Conforme mostrado neste trabalho, há uma única portaria que cria a comissão de governança corporativa sem atribuições definidas. Fomos informados pela a Assessoria Técnica de que essa comissão ainda não tinha tido nenhuma reunião para tratar de sua composição.

Em outros órgãos públicos do poder executivo não haviam em suas estruturas organizacionais apresentadas nos sites referências sobre governança. A exceção vem do poder legislativo com várias referências em sua estrutura organizacional e no poder judiciário seguindo o mesmo caminho do poder legislativo.

\section{FUNÇÃO DE GOVERNANÇA E DE GESTÃo}

A governança tem como função principal resolver conflitos de interesse entre os diversos agentes que influenciam uma empresa ou uma instituição. No caso do setor público as influencias vêm dos servidores da instituição, servidores de outros órgãos demandantes e da sociedade. Segundo (CORREIA; AMARAL, 2006), esses tipos de relacionamento são analisados pela teoria dos custos de transação e, principalmente, pela teoria da agência, que explicam e tentam solucionar as divergências entre proprietários e gerentes em uma dimensão econômica. 


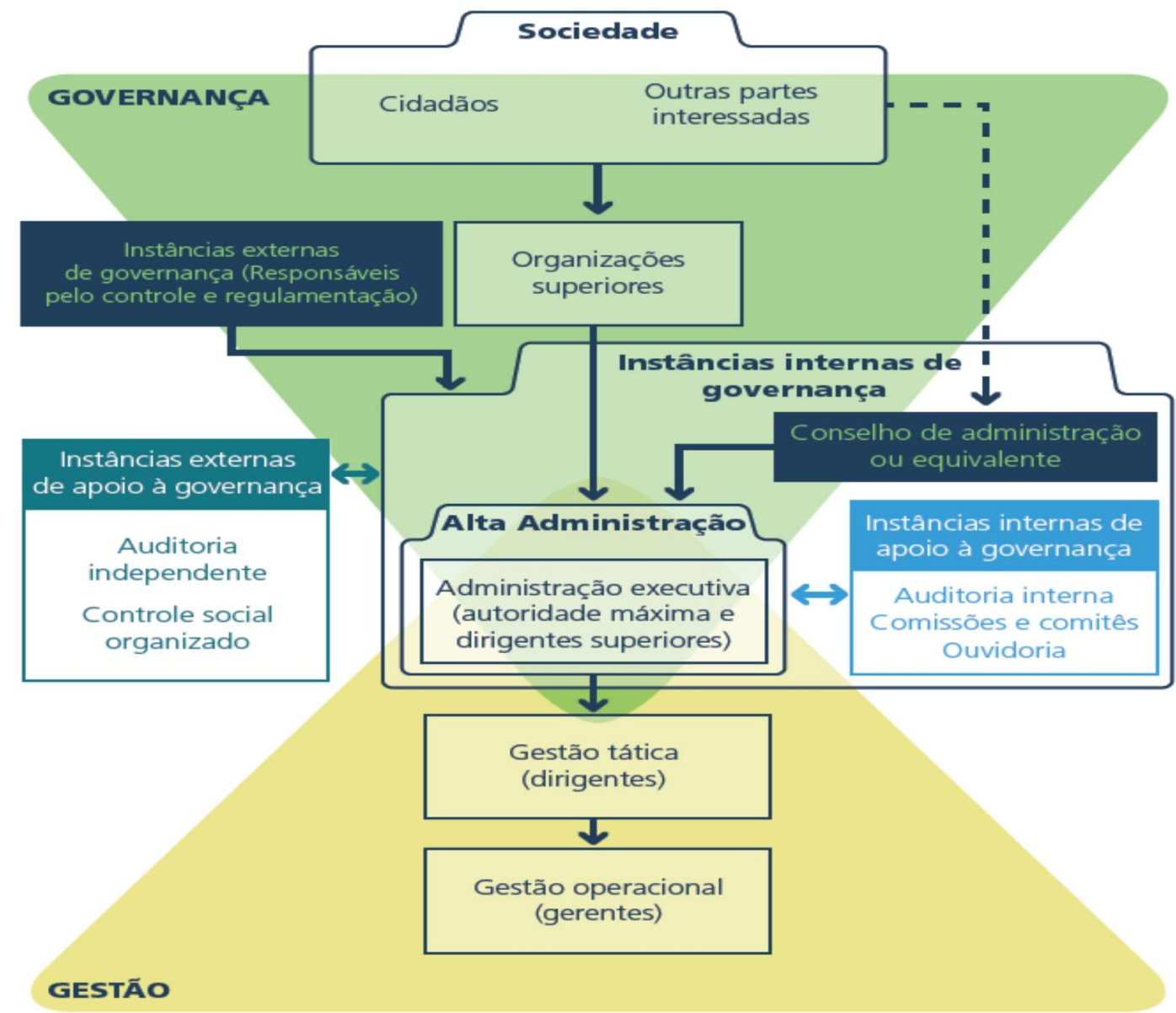

Fonte: (TCU, Referencial Básico de Governança Aplicável a órgãos e Entidades da Administração Pública e Ações Indutoras de Melhorias, 2011)

A figura 3, por exemplo, aponta para um modelo referencial de governança aplicável a órgãos e entidades da administração pública. No modelo de governança proposto no nesta figura, se comparado com a realidade, podemos concluir que o IPEA não estaria dentro do modelo, pois a alta administração não busca formar efetivamente uma equipe de governança - apesar de uma norma interna prevê isso - que possa atuar naquela área comum entre a governança e a gestão e dê todo o apoio necessário a sua atuação.

Afinal, quais são as funções da governança? E quais as funções de gestão? 
a) As funções de governança são: definir o direcionamento estratégico; supervisionar a gestão; envolver as partes interessadas; gerenciar riscos estratégicos; gerenciar conflitos internos; auditar e avaliar o sistema de gestão e controle; e promover a accountability (prestação de contas e responsabilidade) e a transparência (TCU, 2011: P. 47).

b) Já as funções de gestão são: Implementar programas; garantir a conformidade com as regulamentações; revisar e reportar o progresso de ações; garantir a eficiência administrativa; manter a comunicação com as partes interessadas; e avaliar o desempenho e aprender (TCU, 2011: P. 47).

São consideradas funções básicas da governança e gestão nas entidades da administração pública de acordo com o (TCU, 2011 apud ISO/IEC 38500:200855):

a) Avaliar o ambiente, os cenários, o desempenho e os resultados atuais e futuros;

b) Direcionar e orientar a preparação, a articulação e a coordenação de políticas e planos, alinhando as funções organizacionais às necessidades das partes interessadas (usuários dos serviços, cidadãos e sociedade em geral) e assegurando o alcance dos objetivos estabelecidos; e

c) monitorar os resultados, o desempenho e o cumprimento de políticas e planos, confrontando-os com as metas estabelecidas e as expectativas das partes interessadas.

De acordo com o TCU (2011) governança diz respeito a estruturas, funções, processos e tradições organizacionais que visam garantir que as ações planejadas (programas) sejam executadas de tal maneira que atinjam seus objetivos e resultados de forma transparente. Busca, portanto, maior efetividade (produzir os efeitos pretendidos) e maior economicidade (obter o maior benefício possível da utilização dos recursos disponíveis) das ações.

\footnotetext{
${ }^{5}$ ISO / IEC 38500 é uma norma internacional para a governança corporativa de tecnologia da informação publicada conjuntamente pela Organização Internacional de Normalização (ISO) e a Comissão Eletrotécnica Internacional (IEC). Ele fornece um framework para a governança eficaz de TI para ajudar o mais alto nível das organizações a compreender e cumprir as suas obrigações legais, regulamentares e éticas no contexto da utilização de TI de suas organizações. ISO / IEC 38500 é aplicável as organizações de todos os tamanhos, incluindo órgãos públicos e empresas privadas, entidades governamentais e organizações não-lucrativas. http://www.iso.org/iso/catalogue detail.htm?csnumber=62816
} 
O TCU (2011) afirma também que, de forma complementar, a gestão diz respeito ao funcionamento do dia a dia de programas e de organizações no contexto de estratégias, políticas, processos e procedimentos que foram estabelecidos pelo órgão; preocupa-se com a eficácia (cumprir as ações priorizadas) e a eficiência das ações (realizar as ações da melhor forma possível, em termos de custo-benefício).

O modelo de Gespública ${ }^{6}$ lançado oficialmente no Brasil em 1995 com o nome de Programa da Qualidade e Participação na Administração Pública - QPAP citado por (BRANCO; CRUZ, 2013) narra que a liderança é a dimensão de onde se origina a governança e a gestão.

Dentro de uma outra percepção não menos importante para a Governança corporativa se faz necessário discorrer sobre os seis passos oriundos do setor privado, mas que pode contribuir para o setor público. Nesse caso os três primeiros passos fazem referência a esfera pessoal da organização - liderança, compromisso e integridade - e os outros três fazer referência a estratégia da organização responsabilidade, transparência e integração, (MONTEIRO; HAMMES, 2015).

a) Liderança: na esfera do setor público, é essencial para a governança corporativa o desenvolvimento de lideranças em todos os órgãos e níveis da administração. $\mathrm{O}$ administrador público precisa ter uma clara identificação e articulação de competências e responsabilidades para todos os que administram os recursos públicos a fim de obter resultados positivos em conjunto com uma lúcida e transparente comunicação;

b) Compromisso: as boas práticas de governança corporativa no setor público requerem um sólido senso de compromisso por parte de todos os gestores comprometendo-se a estabelecer um eficiente meio de comunicação e gerenciamento no desafio de implantar a GC e seus princípios no setor público;

c) Integridade: a integridade é relacionada com a honestidade. A administração pública contempla muitas responsabilidades, por isso este princípio é relevante, pois a maneira como o profissionalismo e os valores pessoais das pessoas são conduzidos

\footnotetext{
${ }^{6}$ O Programa Nacional de Gestão Pública e Desburocratização - GESPÚBLICA é um programa do Governo Federal, instituído pelo Decreto $\mathrm{n}^{\mathrm{0}} 5.378$, de 23 de fevereiro de 2005, que tem por objetivo estimular e apoiar os órgãos e entidades públicos a implementarem medidas de fortalecimento em sua gestão interna, a fim de oferecerem serviços de melhor qualidade aos cidadãos. Disponível em: $\leq$ http://www.planejamento.gov.br/servicos/faq/gestao-publica/gestao-publica-referenciais-de-excelenciamodelos/o-que-e-o-programa-nacional-de-gestao-publica-e $>$
} 
e desenvolvidos em uma organização, afeta diretamente a eficácia das boas práticas de governança corporativa e também a confiabilidade nas prestações de contas disponibilizadas para a sociedade;

d) Responsabilidade (accountability): os princípios da governança corporativa visam identificar responsabilidades dos agentes envolvidos na organização, considerando quem é responsável perante a quem, e quando. Isso requer uma análise clara dos papéis dos agentes de GC, principalmente dos que ocupam os cargos de líderes, pois sem esta identificação os resultados almejados podem ser prejudicados;

e) Transparência: a sociedade exige cada vez mais transparência nas ações da gestão do setor público e para este setor é importante conquistar a confiança da população e uma das formas mais eficazes de conquistar essa confiança é através de uma significativa divulgação de relatórios claros e transparentes através de comunicações completas e seguras. A transparência também contribui para evidenciar a responsabilidade social por parte dos dirigentes e isso é deveras importante na aplicação da governança corporativa.

f) Integração: além do desafio de definir uma efetiva governança corporativa no setor público, outro desafio é garantir a integração dos princípios para que sejam compreendidos e abordados pelos funcionários e corretamentente aplicados na organização, pois a correta implantação da governança corporativa, pode gerar um bom quadro estratégico importante para o atingimento de metas e objetivos.

Tais citações condizem com os parâmetros para análise do Plano Estratégico 2013-2023. A figura 2, por exemplo, representa um modelo onde a liderança é a dimensão de onde se origina a governança e a gestão. Ou seja, a liderança institucional estabelece diálogos e compromissos com os cidadãos e a sociedade, $\mathrm{e}$ transforma tais compromissos em estratégias e planos que definem como as pessoas e os processos da instituição são organizados e geridos para obter resultados (serviços de qualidade) em prol do cidadão e da sociedade. (BRANCO; CRUZ, 2013. P: 22 e 23). 
Figura 4- Critérios de Análise do GESPÚBLICA (Brasil 2010)

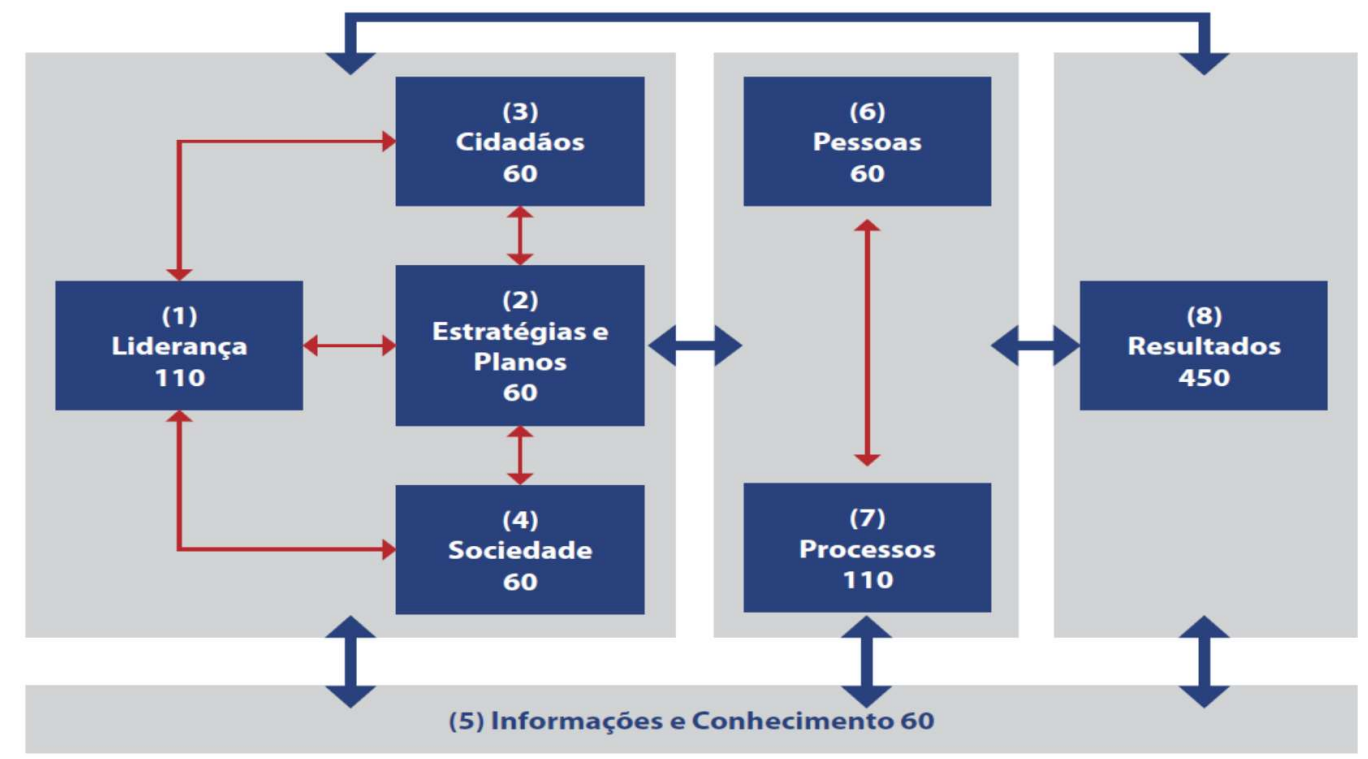

Fonte: (BRANCO; CRUZ, 2013)

$\mathrm{Na}$ prática, analise-se as informações coletadas das pesquisas realizadas junto ao público interno e externo do IPEA levando em conta o papel da liderança como ferramenta da governança, onde se busca extrair a eficiência do plano estratégico nos diversos aspectos propostos. Nesse sentido, para que o papel da governança seja plenamente atendido é necessário conhecer, propor direcionamento, sugerir e prestar conta.

\section{GOVERNANÇA CORPORATIVA NO IPEA}

A governança no IPEA está registrada por meio do Comitê consultivo de governança corporativa, criado pelas portarias $n^{\circ} 319$, de 16 de dezembro de 2015 e $n^{\circ}$ 106, de 28 de abril de 2016. Antes disso, em 2013 o IPEA lança um plano estratégico que visa estender-se até o ano de 2023 com vistas a direcionar suas atribuições. Sua missão está focada no aprimoramento de políticas públicas essenciais ao desenvolvimento brasileiro por meio da produção e disseminação de conhecimento e 
da assessoria ao Estado nas suas decisões estratégicas, decreto $\mathrm{n}^{0} 7.142$, de 29 de março de $2010^{7}$.

A questão chave tratada nesta pesquisa faz referência ao acompanhamento das ações propostas no plano estratégico com base nas regras da boa governança no setor público. Os caminhos apontados dizem respeito ao público alvo e os benefícios que o IPEA pretende atingir em cumprimento aos seus deveres. Para tanto, em razão de sua missão institucional, a instituição busca mais eficiência nas relações com o Governo Federal, a sociedade e os poderes Legislativo e Judiciário.

Antes de entrar propriamente no Plano Estratégico do IPEA, devemos lembrar que a instituição sempre passou por dificuldades de relacionamentos entre suas diretorias, coordenações e unidades. Com base nestas condições, a produção do IPEA levantada em número de publicações, seminários, artigos, livros e comparadas com o recurso disponível, recurso efetivamente executado, a força de trabalho disponível, de modo a identificar o nível de eficiência após a implantação do plano estratégico.

O Plano Estratégico do IPEA 2013-2023 é considerado uma ferramenta importante diante das condições atuais da administração. O plano, em sua base, define como pontos focais identificar as tendências do ambiente externo; fazer um diagnóstico interno dos pontos fortes fracos da instituição; fazer entrevistas com atores externos e internos e o Benchmarking (processo de avaliação em relação à concorrência).

\footnotetext{
${ }^{7}$ Decreto ${ }^{\circ}$ 7.142, de 29 de março de 2010, aprova o Estatuto e o Quadro Demonstrativo dos Cargos em Comissão e das Funções Gratificadas do Instituto de Pesquisa Econômica Aplicada - IPEA, e dá outras Providências.
} 
Figura 5- Governança e Construção do Plano Estratégico do Ipea

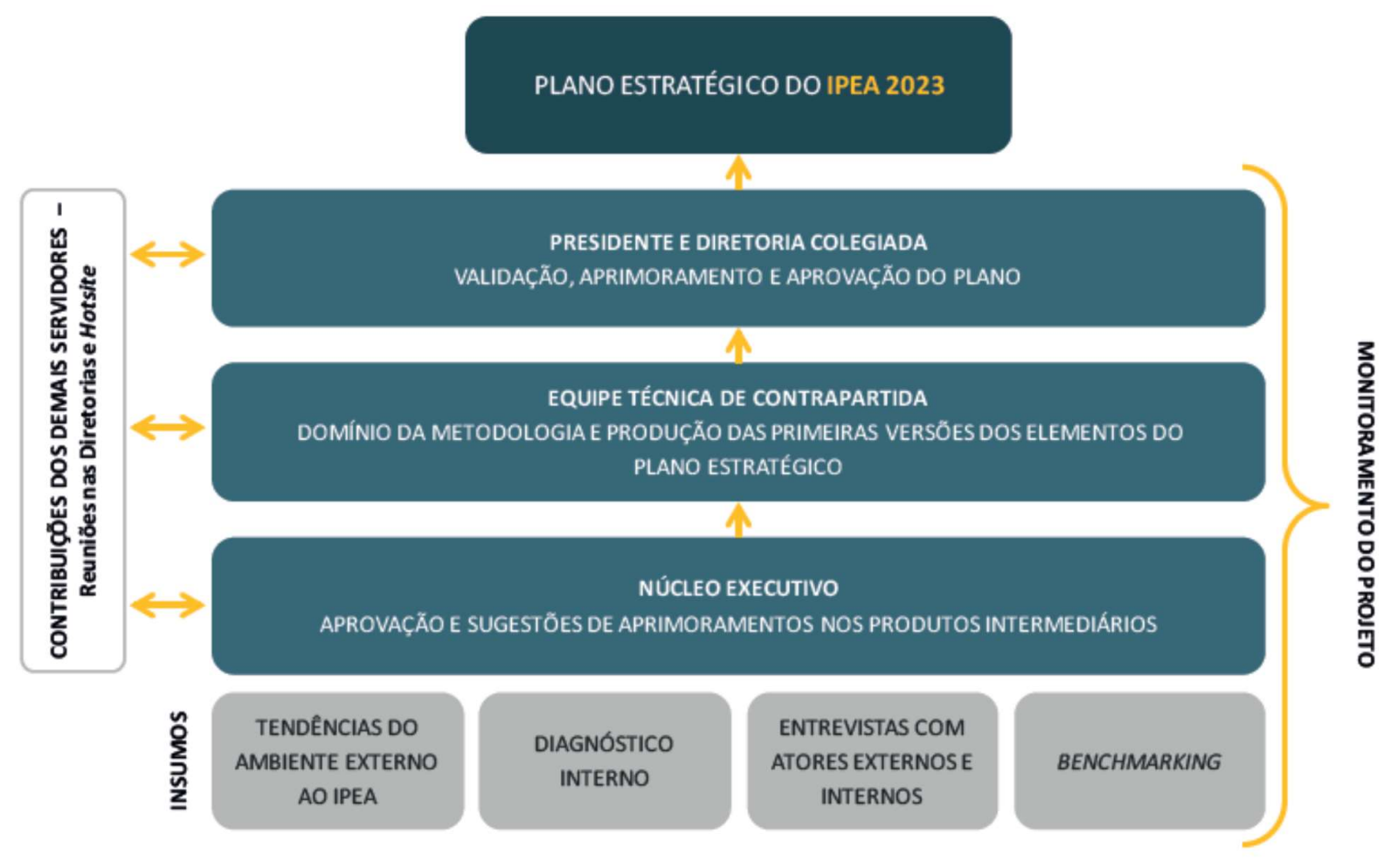

Fonte: PLANO ESTRATÉGICO DO IPEA 2013 - 2023, pg. 45

Desde 2013 o modelo de plano estratégico acima proposto está em execução. Qual é a ideia aqui proposta que temos para analisar a execução desse plano a luz da governança corporativa que embase a avaliação da qualidade dos serviços prestados? Bom, a princípio dispomos os dados da produção do IPEA, especificamente os dez itens definidos no contexto da estrutura definida anteriormente.

Algumas situações devem ser observadas na produção após um ano de implantação do plano estratégico. Nos anos de 2010, 2011, 2012 e 2013 o relatório de atividades do IPEA não definiu claramente as metas contratadas. Nesse caso, só no ano de 2013 é que algumas diretorias tinham metas definidas. Já em 2014 o relatório de atividades veio com todas as metas contratadas e as quantidades executadas. Isso demostra algum efeito da implantação do plano estratégico. 
Quadro 2- Produção do IPEA

\begin{tabular}{|c|c|c|c|c|c|c|c|c|c|c|c|}
\hline \multicolumn{12}{|c|}{ METAS FINALÍSTICAS CONTRATADAS E EXECUTADA NOS ÚLTIMOS 5 ANOS } \\
\hline \multirow{2}{*}{$\begin{array}{r}\text { Item } \\
1\end{array}$} & \multirow{2}{*}{$\begin{array}{l}\text { Atividade Finalística } \\
\text { Apresentação de artigos ou } \\
\text { papers em eventos ou } \\
\text { seminários }\end{array}$} & \multicolumn{2}{|c|}{2010} & \multicolumn{2}{|c|}{2011} & \multicolumn{2}{|c|}{2012} & \multicolumn{2}{|c|}{2013} & \multicolumn{2}{|c|}{2014} \\
\hline & & 0 & 0 & 0 & 3 & 0 & 0 & 0 & 121 & 71 & 118 \\
\hline 2 & $\begin{array}{l}\text { Publicação de artigos em } \\
\text { boletim do Ipea ou outros } \\
\text { periódicos }\end{array}$ & 0 & 13 & 0 & 54 & 0 & 86 & 4 & 53 & 71 & 134 \\
\hline 3 & $\begin{array}{l}\text { Desenvolvimento de capítulos } \\
\text { de livros }\end{array}$ & 0 & 0 & 0 & 11 & 0 & 0 & 0 & 148 & 126 & 258 \\
\hline 4 & $\begin{array}{l}\text { Desenvolvimento de bases de } \\
\text { dados (primárias ou } \\
\text { secundárias) }\end{array}$ & 0 & 36 & 0 & 0 & 0 & 31 & 0 & 4 & 38 & 42 \\
\hline 5 & $\begin{array}{l}\text { Produção de comunicados, } \\
\text { notas técnicas ou position } \\
\text { papers }\end{array}$ & 0 & 39 & 0 & 26 & 0 & 13 & 10 & 26 & 42 & 23 \\
\hline 6 & $\begin{array}{l}\text { Organização de eventos ou } \\
\text { oficinas }\end{array}$ & 0 & 0 & 0 & 32 & 0 & 0 & 33 & 63 & 101 & 119 \\
\hline 7 & $\begin{array}{l}\text { Organização ou edição de } \\
\text { livros }\end{array}$ & 0 & 41 & 0 & 15 & 0 & 28 & 5 & 36 & 24 & 32 \\
\hline 8 & $\begin{array}{l}\text { Organização ou edição de } \\
\text { periódicos do Ipea }\end{array}$ & 0 & 25 & 0 & 7 & 0 & 13 & 0 & 11 & 17 & 22 \\
\hline 9 & $\begin{array}{l}\text { Realização de relatórios de } \\
\text { pesquisa }\end{array}$ & 0 & 0 & 0 & 9 & 0 & 37 & 0 & 27 & 119 & 133 \\
\hline 10 & $\begin{array}{l}\text { Desenvolvimento de textos para } \\
\text { discussão }\end{array}$ & 0 & 111 & 0 & 88 & 0 & 123 & 24 & 127 & 124 & 99 \\
\hline & & & Meta & пाт & ada & & & $\mathrm{Me}$ & Rea & ada & \\
\hline
\end{tabular}

Fonte: Relatórios de Atividades do IPEA (2010, 2011, 2012, 2013 e 2014).

As consequências da falta de uma definição clara do objeto de trabalho da instituição deixam margem às diretorias e seus técnicos trabalharem em temas de interesse fora das metas institucionais a serem cumpridas anualmente. Prova disso está na falta de coordenação que defina as melhores práticas calcadas nos princípios propostos na unidade das instituições públicas em que sua missão é servir a sociedade. $\mathrm{Na}$ literatura pesquisada fica claro que esse princípio está longe de ser alcançado em 
razão de diversos gargalos internos e externos. Podemos citar que a diversidade de visões contribui sobremaneira para o desenvolvimento da instituição, no entanto, quando essa visão tem a ver com aspectos culturais do indivíduo, isso pode ser prejudicial em razão da falta de convergência para um bem comum das atividades públicas.

Observar-se no quadro 2 que os anos anteriores à implantação do Plano Estratégico 2013 - 2023 não havia unidade na definição das metas finalísticas nem a definição das metas contratadas e metas realizadas. Essas metas contratadas e realizadas só foram bem definidas no ano de 2014, pois não havia um trabalho conjunto em prol de resultado comum.

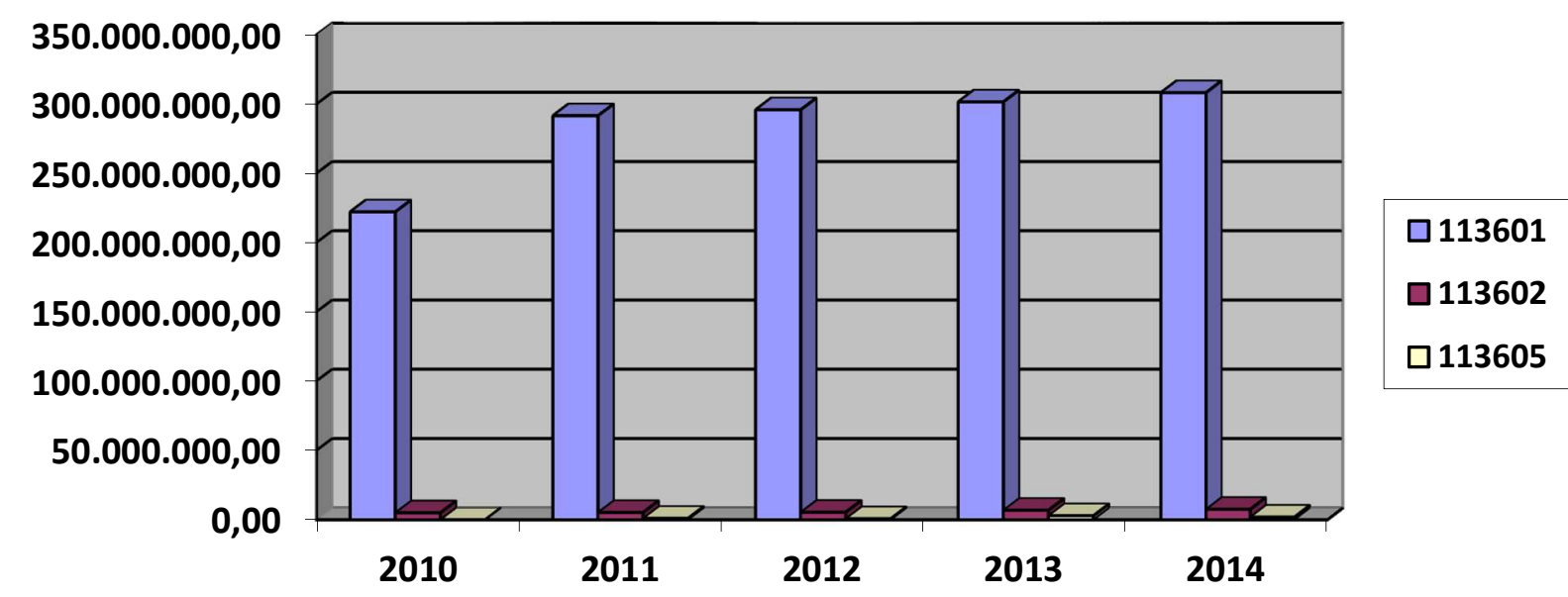

Fonte: Portal da Transparência do Governo Federal.

A unidade orçamentaria 113601 é o IPEA em Brasília; a unidade orçamentaria 113602 é o IPEA Rio de Janeiro e unidade orçamentaria 113605 representa financiamentos de projetos do IPEA pelo BID.

No gráfico 1 mostra execução orçamentaria de cinco anos anteriores. Os dados servirão para comparação com outros dados tendo como proposito demonstrar a eficiência ou não na implantação do plano estratégico 2013 - 2023. 
Tanto no IPEA, quanto em toda a Administração Pública a execução orçamentária segue uma tendência de aumento constante das despesas mesmo com os diversos cortes orçamentários feitos pelo Governo central em razão da não confirmação da arrecadação prevista no orçamento anual da união juntamente com a estimativa de gasto para o mesmo exercício.

Como é observado no gráfico 2 , se compararmos a execução orçamentaria fica clara a questão da tendência de elevação das despesas mesmo em anos de crise como ocorreu entre 2013 e 2014.

Gráfico 2- Execução Orçamentária - Custeio e Investimento do IPEA

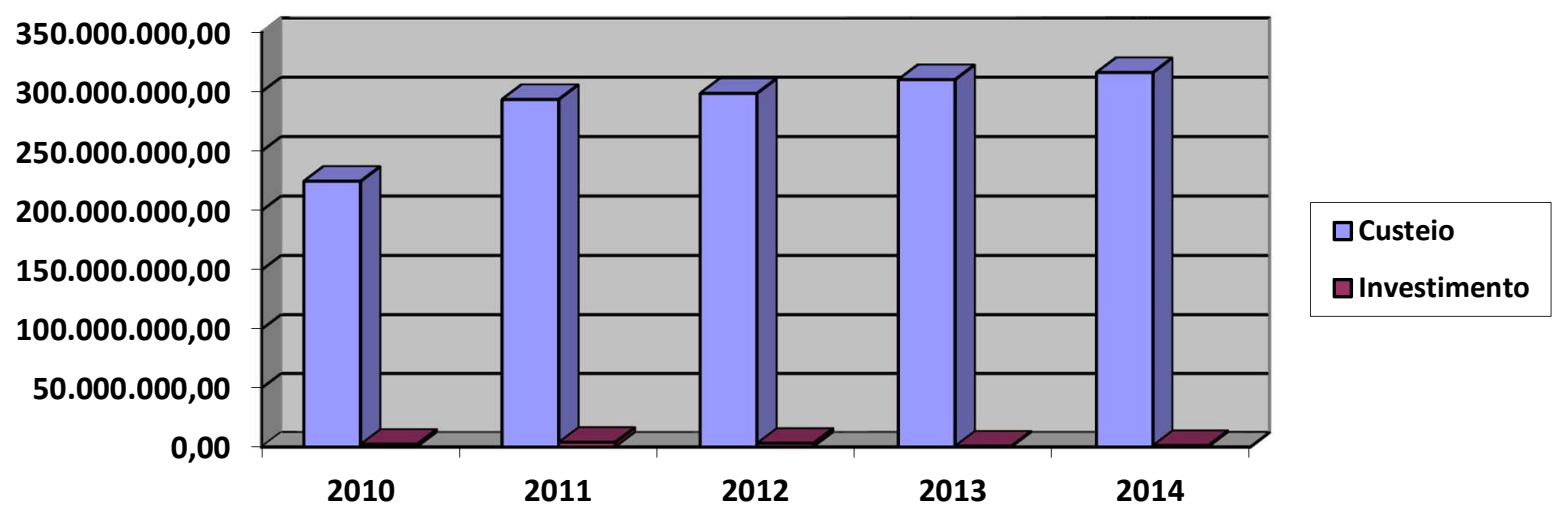

Fonte: Portal da Transparência do Governo Federal.

A execução orçamentaria como um todo segue uma tendência crescente mesmo sem investimento em melhorias estruturais, novas tecnologias de pesquisa, contratação de mão de obra, treinamentos. Se comparado com o gráfico 3, temos uma tendência de perda de mão de obra especializada sem perspectivas de reposição e com a manutenção da tendência de crescimento das despesas. 


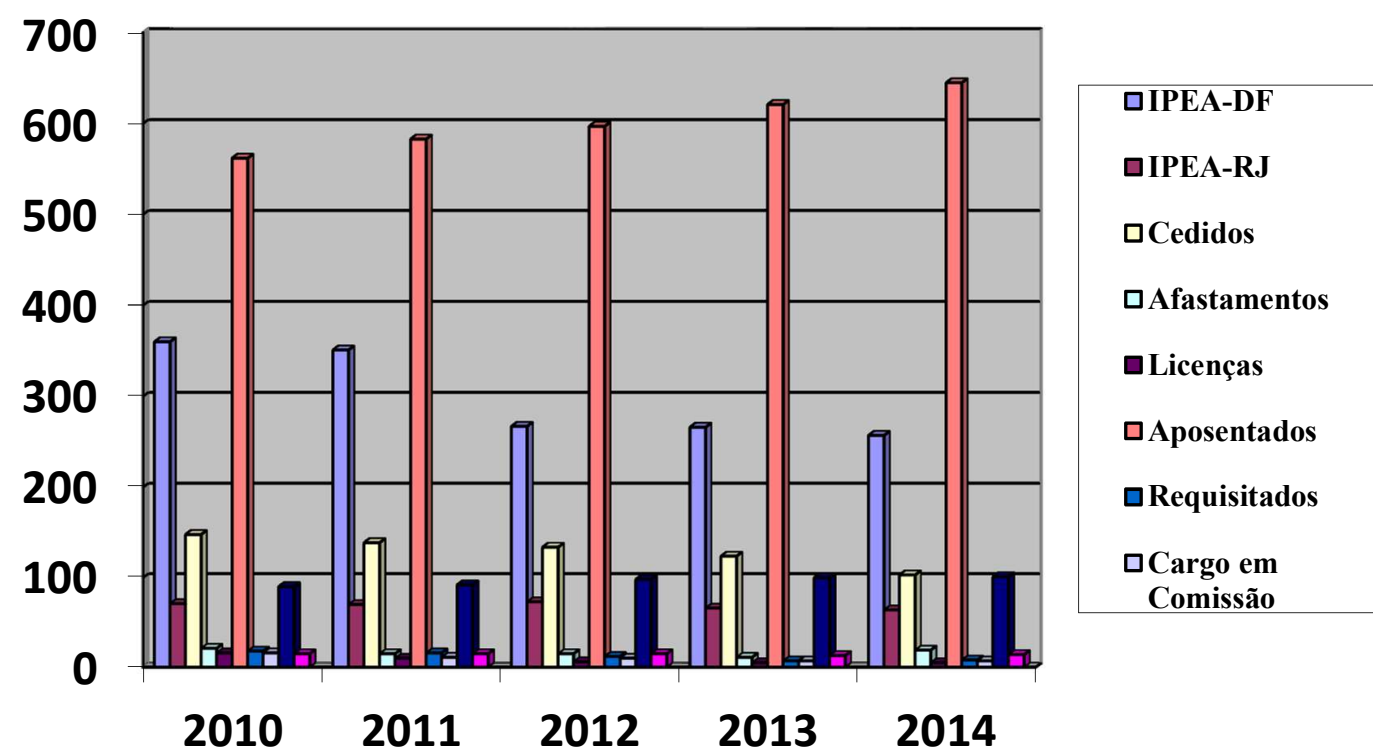

Fonte: CGPES/IPEA

Aparentemente o cenário não é dos mais favoráveis para o IPEA neste momento. Mesmo com o quadro atual é possível a correção de rumos, basta observamos as propostas do Plano Estratégico do IPEA 2013-2023 sintetizado na figura 5 .

Quadro 3- Serviços Prestados pelo IPEA a Sociedade

\begin{tabular}{|l|l|}
\hline \multicolumn{2}{|c|}{ Serviços Finalísticos } \\
\hline 1 & $\begin{array}{l}\text { Avaliar e propor políticas públicas e programas essenciais para o desenvolvimento } \\
\text { do país }\end{array}$ \\
\hline 2 & $\begin{array}{l}\text { Formular estudos prospectivos para orientar estratégias de desenvolvimento de } \\
\text { médio e longo prazo }\end{array}$ \\
\hline 3 & $\begin{array}{l}\text { Assessorar o Estado na melhoria da qualidade de suas decisões } \\
\text { Contribuir para a qualificação do debate público quanto aos rumos do } \\
\text { desenvolvimento do pais e da ação do Estado }\end{array}$ \\
\hline \multicolumn{1}{|c|}{ Serviços de Gestão } \\
\hline
\end{tabular}




\begin{tabular}{|l|l|}
\hline 1 & Assegurar produtividade com qualidade e quantitativo adequado de servidores \\
\hline 2 & Garantir confiabilidade, agilidade e efetividade aos processos e sistemas de gestão \\
\hline 3 & Fortalecer e articular a comunicação interna e externa \\
\hline 4 & Garantir foco e sinergia ao plano de trabalho \\
\hline
\end{tabular}

Fonte: Plano estratégico do IPEA 2013-2023 (2014)

\subsection{O PLANO ESTRATÉGICO DO IPEA}

De acordo com as funções da governança no setor público - definir o direcionamento estratégico; supervisionar a gestão; envolver as partes interessadas; gerenciar riscos estratégicos; gerenciar conflitos internos; auditar e avaliar o sistema de gestão e controle; e promover a accountability (prestação de contas e responsabilidade) e a transparência - o acompanhamento do plano estratégico do IPEA segue em duas etapas: objetivos estratégicos finalísticos; objetivos estratégicos de gestão.

Figura 6-Fluxo do Processo de Planejamento do IPEA

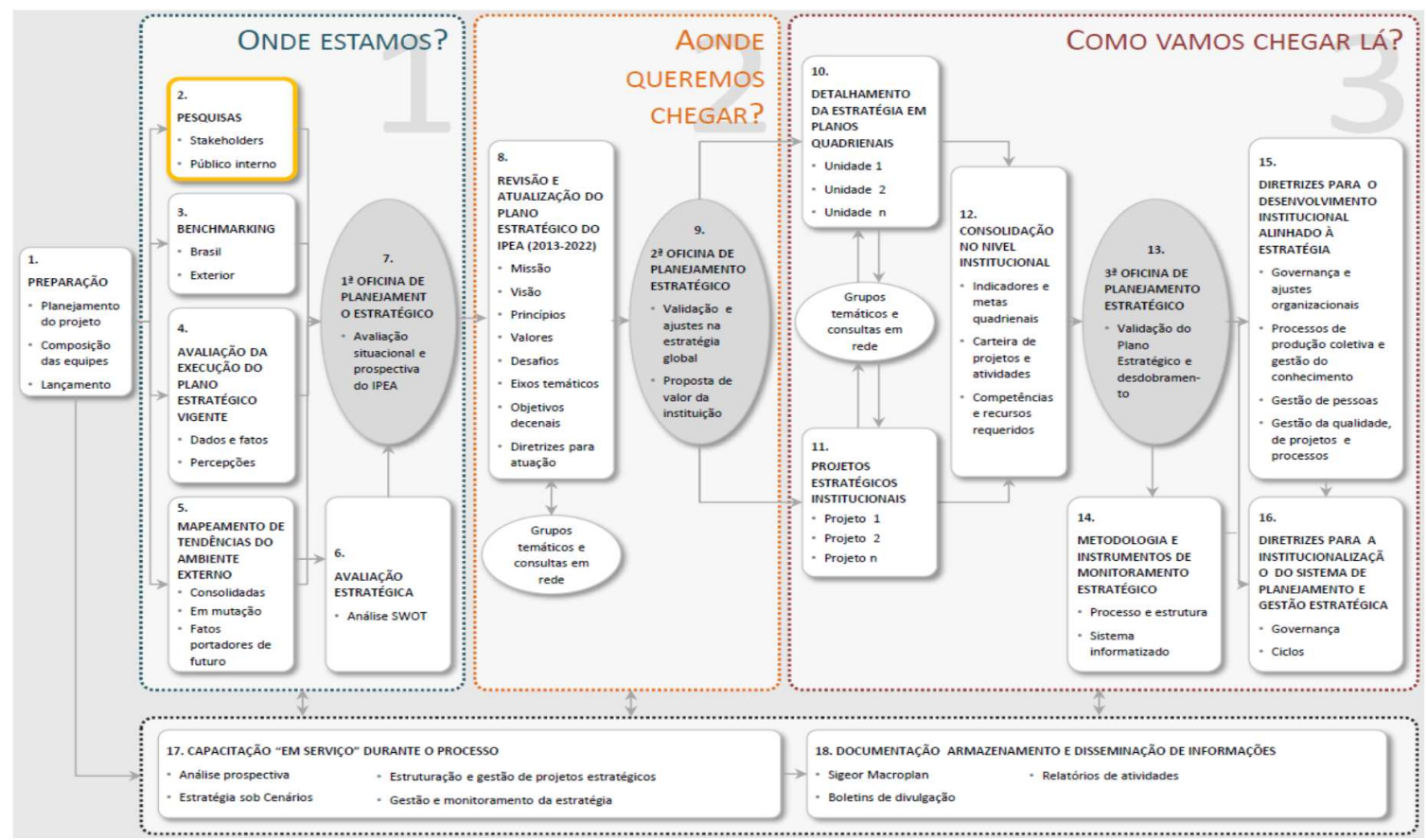

Fonte: (IPEA, 2013a), Diagnostico interno-resultado da pesquisa com quadro de colaboradores, 2013. 
O objetivo estratégico finalístico se subdivide em quatro partes apresentados com a seguinte proposta, (IPEA, 2013b):

1. Avaliar e propor políticas públicas e programas essenciais para o desenvolvimento do país:

a) Realizar pesquisa de excelência para apoiar as políticas públicas e programas essenciais ao desenvolvimento;

b) Garantir a representação do Ipea em colegiados consultivos e deliberativos de políticas públicas para influenciar a construção da agenda institucional;

c) Ampliar o assessoramento e a cooperação com os órgãos governamentais mais relevantes para influenciar a avaliação e formulação de políticas públicas e programas. Manter o quadro técnico do Ipea informado e atualizado sobre a agenda institucional de políticas públicas;

d) Ampliar o acesso e uso de bases de dados necessárias à avaliação e à proposição de políticas públicas (IPEA, 2013b).

2. Formular estudos prospectivos para orientar estratégias de desenvolvimento de médio e longo prazo:

a) Ofertar aos órgãos decisórios estudos prospectivos para antecipar impactos e identificar temas estratégicos para o desenvolvimento brasileiro;

b) Ofertar aos órgãos decisórios estudos prospectivos setoriais e regionais que subsidiem o aprimoramento de políticas públicas e programas estratégicos;

c) Propor e desenvolver pesquisas e metodologias relacionadas à prospecção;

d) Assessorar instituições públicas na elaboração de estudos prospectivos (IPEA, 2013b).

3. Assessorar o Estado na melhoria da qualidade de suas decisões:

a) Pesquisar e produzir diagnósticos sobre os principais problemas que impactam na agenda prioritária do Estado;

b) Pesquisar e disseminar temas, propostas e métodos inovadores;

c) Ampliar a prestação de serviços de assessoria ao Estado, de forma que resulte em respostas rápidas e consistentes para solução de problemas prioritários do desenvolvimento;

d) Ter sistema atualizado com informações, estudos e indicação de pessoas e instituições relacionados às políticas e programas prioritários do Estado; 
e) Aumentar a capacidade de resposta do Ipea, por meio da mobilização de redes e maior produtividade no uso de bases de dados(IPEA, 2013b).

4. Contribuir para a qualificação do debate público quanto aos rumos do desenvolvimento do pais e da ação do Estado:

a) Identificar, pesquisar e disseminar temas relevantes e emergentes na sociedade;

b) Disponibilizar, em formatos adequados, as informações e conhecimentos produzidos pelo Ipea para atores da sociedade, incluindo locais e internacionais;

c) Auscultar, articular e subsidiar os atores sociais relevantes para o desenvolvimento, por meio de redes e de diferentes canais de interação(IPEA, 2013b).

Já os objetivos estratégicos de gestão se subdivide em quatro partes que ficou assim subdividido:

\section{Assegurar produtividade com qualidade e quantitativo adequado de servidores:}

a) Desenvolver a qualificação dos servidores, particularmente em metodologias de avaliação, prospecção e competências gerenciais, alinhada ao Plano Estratégico;

b) Estruturar e qualificar a gestão de pessoas com uma política de incentivo ao desempenho;

c) Propiciar ambiente e condições de trabalho motivadores;

d) Viabilizar a adequação permanente do perfil e do quantitativo de pessoal por meio de políticas de ingresso, alocação e retenção de talentos;

e) Implantar política corporativa para relaciona- mento com pesquisadores externos, bolsistas e terceirizados, com foco na profissionalização das relações, monitoramento e fiscalização (IPEA, 2013b).

2. Garantir confiabilidade, agilidade e efetividade aos processos e sistemas de gestão:

a) Assegurar a gestão estratégica para garantir a atualização e o monitoramento do Plano Estratégico;

b) Aprimorar a gestão por projetos com critérios claros para a alocação de recursos;

c) Aprimorar e integrar os processos e os sistemas de gestão para assegurar transparência, agilidade e economicidade; 
d) Redesenhar os processos críticos, de modo a aumentar sua confiabilidade, eficiência e eficácia (IPEA, 2013b).

\section{Fortalecer e articular a comunicação interna e externa:}

a) Qualificar a comunicação interna, com o intuito de criar um ambiente cooperativo e de amplo acesso às informações de interesse do servidor;

b) Assegurar transparência às decisões tomadas no âmbito da diretoria colegiada e de outras instâncias decisórias;

c) Definir uma política institucional de relacionamento com o público externo, particularmente com a mídia;

d) Divulgar os resultados de estudos e pesquisas em linguagem adequada aos diferentes atores nacionais e internacionais;

e) Aprimorar canais e espaços de diálogo entre o Ipea e seus principais parceiros e públicos (IPEA, 2013b).

\section{Garantir foco e sinergia ao plano de trabalho:}

a) Aprimorar o processo de elaboração do Plano de Trabalho, de modo a garantir a definição e desdobramento dos projetos em conformidade com o Plano Estratégico;

b) Promover e incentivar a construção coletiva de projetos entre diretorias e coordenações;

c) Aprimorar política de celebração e operacionalização de acordos e convênios visando garantir seu alinhamento com o Plano Estratégico do Ipea;

d) Aperfeiçoar e institucionalizar a gestão do conhecimento e da inovação;

e) Criar espaços e instrumentos institucionais de acompanhamento e debate sobre a conjuntura nacional, com disseminação de seus resultados na Instituição (IPEA, 2013b).

Definido o plano estratégico, o desafio passa a ser a implementação. Na visão de longo prazo proposto relatório implementar o plano "envolve muitas outras etapas, sendo a primeira delas a sua decomposição em ações de médio e curto prazo. Este desmembramento é condição básica para que se consiga fazer a estratégia acontecer em sequências lógicas e contínuas e, ao mesmo tempo, garantir flexibilidade para fazer as correções de rumos, caso haja alterações relevantes nos ambientes externo ou interno da Instituição (captadas pelas ações de monitoramento)", (IPEA, 2013c). 
Nessa visão de longo prazo idealizada pelo plano se integra a outros planos de trabalho de médio prazo das Diretorias, os planos táticos se desdobram nos orçamentos de cada ano com o objetivo de haver sintonia entre os prazos de elaboração do orçamento e os prazos de definição dos projetos estratégicos.

\section{PROCEDIMENTOS METODOLOGICOS DA PESQUISA}

A metodologia utilizada nesta pesquisa consiste na análise relacionada aos itens propostos no Plano Estratégico do IPEA que tem por finalidade dimensionar os objetivos estratégicos: objetivos estratégicos finalísticos e objetivos estratégicos de gestão. A pesquisa realizada neste trabalho foi exploratória, qualitativa e quantitativa. Exploratória porque teve como objetivo proporcionar maior familiaridade com o problema, envolvendo levantamento bibliográfico, entrevista com pessoas que tiveram experiências práticas com o tema pesquisado e análise de exemplos para auxiliar a compreensão; qualitativa, pois visa descrever as características de uma determinada população, no caso, a estrutura de governança do IPEA, mediante pesquisas e entrevistas (GIL, 2002) e quantitativa, pois apontar numericamente a frequência e a intensidade dos comportamentos dos indivíduos de um determinado grupo ou população.

Quanto aos meios de investigação foram realizadas três abordagens:

a) Pesquisa bibliográfica, que é realizada a partir de material já publicado, como livros, artigos de periódicos e materiais disponibilizados na Internet (GIL, 1998 apud MAGALHÃES, 2011, p. 36);

b) Pesquisa documental, realizada em documentos internos de órgãos públicos (GIL, 1998 apud MAGALHÃES, 2011, p. 36).

c) Pesquisa amostral de uma determinada população de servidores, colaboradores e bolsistas do IPEA.

Os documentos pesquisados neste trabalho fazem parte de uma pesquisa interna do IPEA que trata da implantação do Plano Estratégico 2013-2023 que tem por finalidade a melhoria do Planejamento Estratégico e Desenvolvimento Institucional da instituição. Tais parâmetros de investigação segue a análise conjuntural da governança corporativa no setor público por meio dos princípios de governança corporativa definidos no item 2.2 . 


\subsection{PERCEPÇÃO DAS CONDIÇÕES DE ATUAÇÃO INTERNA}

A pesquisa qualitativa com os atores internos ao IPEA aponta a dificuldade comum a todas as instituições públicas quanto ao desenvolvimento de suas atividades. Desse ponto de vista descrevemos abaixo as condições de atuação em que os servidores enfrentam no dia a dia da instituição:

1. Limitada a efetividade dos estudos (existe a percepção de que a capacidade do IPEA de influenciacão, aproveitamento e reconhecimento por parte do governo federal ainda é baixo):

a) O Ipea coloca a questão do desenvolvimento em pauta, mas muitas vezes a maneira de como o governo pode trazer isso para a sua prática cotidiana, transformando isso em políticas públicas e em inovações na gestão governamental; esse passo fundamental ainda está faltando;

b) No governo, a visão das pessoas é a de que o IPEA faz a pesquisa descolada da visão e da agenda do Estado brasileiro, fora do tempo político;

\section{Baixa articulação com o Governo Federal:}

a) Há uma falta de conexão ente os temas tratados pelo Ipea e a estratégia perseguida pelo Governo. O Ipea precisa identificar um número menor de alvos se quiser alcançar maior efetividade. É natural que cada pesquisador queira perseguir sua agenda. Mas de onde parte a missão do Ipea? Qual a relação entre Ipea e Governo Federal? Não se pode mover o Ipea a partir das inquietações dos seus pesquisadores, é preciso ter um cuidado maior com as demandas do Governo;

b) Há um certo distanciamento do Ipea em relação a alguns Ministérios (...) o Pesquisador acha que muitas vezes (outros) Ministérios não enxergam o Ipea como parceiro. (...) Acaba que fica uma instituição muito fechada em si mesma que poderia e deveria se abrir e contribuir com o conjunto do Governo;

3. Desarticulação e falta de foco da agenda de pesquisa:

a) O Ipea trabalha uma quantidade muito grande de temas e questões. Trata-se de um grande areal temático, associado a um conjunto muito elevado determos e projetos de cooperação. Olhando de fora, fica difícil compreender o que o Ipea pretende de fato alcançar. Entendo que existe uma abertura excessiva de temas. (...) O Ipea hoje trabalha um espectro de temas muito grande;

b) A escolha da agenda de pesquisa se dá através de um processo natural de 'geração espontânea' de pesquisas, com baixa 
influência dos parceiros do Ipea. O processo como um todo acontece de maneira pouco sistemática. Não há um método para identificar os focos de pesquisa, as principais carências do País e, consequentemente, as políticas públicas prioritárias que precisam ser priorizadas e analisadas pelo Ipea;

c) Cada pesquisador, sentado na sua mesa, decide o que vai fazer em termos de pesquisa.

\section{Pouca visão prospectiva:}

a) O IPEA esteve um pouco distanciado, por uma série de razões, do seu papel, da sua missão de ser um Instituto de planejamento estratégico. A construção de cenários, uma função mais prospectiva, ficou a desejar. Muitas das vezes, isso foi construído por outras instâncias. (...) O IPEA tem um quadro de excelência - é importante -, mas precisa desenvolver mais estudos de cenários estratégicos para o crescimento do Brasil e para onde vão as economias internacionais. Isso era visível no tempo de criação do Ipea. Pouco tempo depois, esse papel também era relevante - o papel de pensar o planejamento, os eixos temáticos da economia -, mas se perdeu um pouco ao longo do caminho e não conseguiu reencontrar;

b) O IPEA fica na avaliação ideológica dos problemas ao invés de apresentar cenários e soluções.

\section{Pouca clareza interna e externa da sua missão:}

a) O pesquisador acha que o grande problema que o IPEA sempre teve é a ambiguidade da missão. Então de um lado você tinha pessoas em Brasília que davam suporte ao governo, iam trabalhar nos Ministérios, e de outro tinha aqueles que achavam que estavam dentro da universidade. Ele acha que (tem que ter) uma missão mais focalizada;

b) O IPEA precisa de uma definição e internalização claras da missão, visão e valores. Suas atribuições não são muito claras e, portanto, elas estão sempre sendo redefinidas e buscadas pela direção em exercício.

\section{Baixa articulação entre diretorias:}

a) Um desafio adicional que é fazer com que o trabalho das Diretorias seja mais sinérgico para que o IPEA alcance um mínimo de coerência. Continuamos tendo uma imensa dificuldade de aproveitar melhor as sinergias;

b) A coordenação multidiretorias é certamente um desafio, como trabalhar juntos de forma orgânica. Achar uma agenda com pontos de contato entre as Diretorias; 
c) A articulação entre as Diretorias é pequena. Sempre se tentou ampliar a interação, mas nunca deu muito certo. (...) Para integrar as Diretorias precisa haver uma estrutura de governança clara;

\section{Gestão de recursos humanos:}

a) O Pesquisador acha que o grande desafio do IPEA é fazer com que as pessoas fiquem motivadas. "Se a gente conseguir enxergar questões em políticas públicas relevantes e acharmos um meio de engajar as pessoas nelas, não teremos muitos problemas. Mas como gerenciar as pessoas sem os instrumentos de incentivos adequados"?

b) É preciso transformar esse potencial (número expressivo de mestres e doutores) em coisas reais. "Temos que montar uma estrutura para evitar que este potencial seja desperdiçado";

c) A principal fragilidade - que é do serviço público como um todo - são as amarras: quando não se consegue diferenciar e premiar as pessoas de maior esforço, a consequência é que todo mundo só se esforça quando bem entende. A estrutura de incentivos 'joga contra.

8. Elaboração dos planos de ação e mensuração de resultados:

a) O primeiro ponto fundamental é reconhecer que um formulário de pesquisa, principalmente nos moldes atuais, não é uma ferramenta de planejamento adequada. Um segundo problema que precisa ser enfrentado é tornar o processo mais participativo;

b) (Os planos de trabalho são) um amontoado de projetos individuais, com poucas e honrosas exceções;

c) O plano de trabalho é fragmentado, desfocado e desigual. Além de feio visualmente. $E$ ele não reflete as diferentes complexidades das pesquisas;

d) Hoje, para a construção do Plano de Trabalho é distribuído um formulário para todos os funcionários do IPEA e cada um preenche com o que quer fazer no próximo ano. E muitos dos temas que aparecem no Plano não estão alinhados com a agenda principal do governo.

\section{Deficiência na comunicação externa:}

a) Grande parte dos técnicos do Ipea tem uma agenda com telefones de jornalistas. Quando não são adequadamente contemplados internamente, entram em contato com eles. Isso é muito ruim. Um grande desafio é que a assessoria de imprensa consiga fazer esse meio de campo. (...). É necessário mais orientação e assessoria para os pesquisadores; 
b) Falta de clareza de até onde pode ir a liberdade de expressão e desarticulação das ações de comunicação externa - no mesmo dia podem sair dois artigos na mídia conflitantes;

c) O IPEA tem graves problemas no site. Parece uma agência de notícias. É necessário focar na disponibilização de publicações e dados, não de notícias aleatórias.

10. Deficiências na comunicação interna e na gestão do conhecimento:

a) O Ipea é regido pelas portarias, e no sistema interno não tem a lista completa das portarias. A portaria são as informações que regulam o nosso trabalho;

b) No Ipea os técnicos sabem muito, porém precisamos saber o que cada um sabe, e evitar retrabalho;

c) A comunicação interna é tratada na informalidade e por afinidades pessoais.

Fonte: (IPEA, 2013, p. 31 a 45 )

\subsection{PERCEPÇÃO DAS CONDIÇÕES DE ATUAÇÃO EXTERNA}

Os principais clientes do IPEA são Governo Federal; os Ministérios; Palácio do Planalto; Ministério do Planejamento, Desenvolvimento e Gestão; outros níveis de governo (Estadual e Municipal); outros clientes difusos (BID, ONU, OCDE, CEPAL, etc.). A pesquisa aponta que a relação do IPEA com os atores externos apresenta desafios a serem enfrentados. Entre eles estão:

1. Carência de instituições, métodos e técnicas voltados a avaliação de políticas públicas:

a) O Brasil tem deficiência na avaliação de políticas, a gente inventa mil coisas e não avalia nenhuma delas. Ter um núcleo dentro do próprio governo que faça isso é importante e poderia ter um efeito multiplicador para as outras administrações estaduais, municipais;

b) Há o aumento da disponibilidade de recursos para essas outras pesquisas (avaliação de resultados) que nós normalmente temos que contratar no mercado, e aliás, muitas delas são pesquisas de valor muito elevado. Muitas são contratadas por licitações, e essas licitações são difíceis, a gente tem que enfrentar um conjunto de recursos, com muita subjetividade;

c) O Brasil tem um importante déficit institucional no que se refere à avaliação de políticas públicas. Com sua experiência na área 
de políticas públicas e com um quadro técnico capacitado, o IPEA poderia ajudar a mitigar este déficit.

2. Baixa capacidade de implantar e avaliar políticas por parte de alguns Estados e Municípios:

a) Alguns Estados têm, mas são poucos, institutos de pesquisas ou instrumentos que consigam fazer esse tipo de avaliação (das políticas). Então, acho que prestar um assessoramento, estou pensando primeiro no governo federal, mas talvez um pouco mais largo, para governos estaduais e municipais, tenho certeza que esse é um projeto de longo prazo e mais ambicioso;

b) Os governos estaduais e tenho certeza que esta é a realidade de governos municipais, têm uma dificuldade muito grande de implementar e avaliar as políticas. Muitas vezes alguns municípios e alguns estados não conseguem obter recursos porque não conseguem habilitar projetos;

3. Carência de pensamento prospectivo e de visão de longo prazo na administração pública:

a) A administração pública precisa começar a introduzir a ideia de longo prazo. Hoje é tudo muito imediatista e isso transforma as políticas públicas em intervenções pontuais;

b) O Brasil desaprendeu a pensar no longo alcance e precisa retomar essa discussão;

c) Apesar dos avanços recentes na capacidade de análise do Governo Federal, os ministérios e órgãos vinculados são, em sua grande maioria, órgãos puramente executores, com baixa capacidade de formulação e de tratar de questões mais estruturais. O Executivo Federal está sujeito a uma rotina administrativa intensa, não havendo espaço para uma reflexão mais prospectiva.

4. Carência de conhecimento, ferramentas e métodos específicos de planejamento e gestão nos diversos níveis de governo:

a) O Ipea poderia contribuir muito na área de gestão. Em relação à gestão pública o Ipea tem ouvido muito a academia e pouco a sociedade e os gestores públicos. (...) Existe uma ciência sendo construída para a gestão, refletindo sobre planejamento e apontando estratégias de desenvolvimento. Isso necessita de um diálogo, pois o cientista tem a liberdade para pensar, enquanto que o cotidiano das políticas públicas precisa de avaliações específicas. Quem tem que construir essa ponte, para que inovações sejam inseridas nos planejamentos e gestões públicas, é o Ipea; 
b) Planejamento de Políticas Públicas. Hoje fala-se muito sobre gestão, mas se esquece que sem planejamento não é possível fazer gestão. Senão, será gestão do que? Da crise? (...) Esse é o momento em que o planejamento deve ser bastante valorizado. (...) Faz-se necessário um plano estruturado para o país. Que esse planejamento possa tirar daí grandes diretrizes para o desenvolvimento nacional. E o papel do Ipea, nesse caso, seria o de olhar tendências de planejamento, de gestão pública e traduzir isso para o uso do governo: chamá-lo para o diálogo e sistematizar essas tendências;

Fonte: (IPEA, 2013, p. 45 a 48)

\subsection{DIMENSÕES AVALIADAS}

Foram analisadas sete dimensões; "planejamento e processo decisório; corpo técnico e administrativo; infraestrutura física e tecnológica; gestão e disseminação do conhecimento; imagem e comunicação; estudos e pesquisas, bases de dados e seminários; questões abertas - expectativas para o futuro", (IPEA, 2013b, P. 48).

Com base nas dimensões estudadas anteriormente este trabalho definiu o teor das afirmativas que compõem os questionários a serem aplicados aos servidores, colaboradores e bolsistas. Os temas abordados foram; negociação e definição das metas individuais; negociação e definição das metas globais; alinhamento do plano de trabalho com os objetivos e diretrizes do IPEA; compreensão do papel e atribuição do grau de participação dos colaboradores no processo de planejamento.

A título de informação, podemos descrever alguns dados, sem levar em conta os critérios estabelecidos para análise da pesquisa, indicam uma direção que a instituição deve seguir para dar mais qualidade aos serviços prestados.

Os atributos dos quais apresentam melhores resultados, apontam para a: "qualidade e quantidade de equipamentos de TI disponíveis, 84\%; imagem perante a mídia em geral, 77\%; qualidade técnica e perfil da equipe fixa de pesquisadores, $75 \%$; imagem perante institutos de pesquisa e universidades, $72 \%$. Outros dados apontam que: o pior atributo avaliado foi o "sistema de gestão de desempenho individual, reconhecimento e valorização profissional do corpo técnico, 30\%”, (IPEA, 2013a). 
Não sequência veremos os resultados de outras dimensões relativas a infraestrutura física e tecnológica, imagem e comunicação da instituição.

Atributos que apresentam resultados satisfatórios: a "existência de corpo técnico que garanta diversidade de visões e perspectivas sobre um mesmo objeto, $68 \%$; disponibilidade de software e outros recursos tecnológicos, 66\%; imagem perante o governo federal, sobretudo a presidência da república, o MPOG e os demais ministérios", (IPEA, 2013ª P: 25).

Do ponto de vista da governança, alguns atributos citados anteriormente devem ser avaliados de modo a tentar identificar a importância no desempenho da instituição como um todo. No entanto, é necessário considerar nas suas atribuições a dependências de outras instituições públicas ou privadas no desenvolvimento dos trabalhos. O que se tem visto nesse caso é que quanto mais a instituição depende de outras instituições, mais difícil é o desenvolvimento de seu trabalho. As razões são diversas, vale aqui lembrar de algumas: interesse financeiro, resistência a mudanças, perda de importância no contexto em que está inserido.

Os atributos considerados mais fracos são: "a gestão sistemática das informações sobre os conhecimentos gerados (armazenamento e disseminação), 40\%; Existência de mecanismos formais de compartilhamento de informações e experiências entre pesquisadores, 39\%; o dimensionamento da equipe fixa de servidores administrativos; Transparência no processo decisório, 38\%; a disseminação internacional dos resultados dos trabalhos realizados (publicação de artigos em revistas internacionais, participação em eventos internacionais e intercâmbio com instituições internacionais), 37\%" contribuem sobremaneira para a falta de interesse no desenvolvimento da missão institucional, (IPEA, 2013 $3^{\mathrm{a}}$. P: 26).

\subsection{COMPARATIVO DE DIMENSÕES AVALIADAS NO IPEA E O MODELO DE AVALIAÇÃO DA QUALIDADE DE SERVIÇO}

De modo a dar mais clareza aos itens de avaliação da qualidade dos serviços no IPEA apresentamos no quadro abaixo as dimensões estudadas e que são importantes para a avaliação da qualidade do serviço na instituição. 
Quadro 4-comparação das dimensões propostas pela ferramenta de avaliação SERVQUAL com as dimensões avaliadas no Plano Estratégico do IPEA 2013 - 2023

\begin{tabular}{|c|c|c|}
\hline & SERVQUAL & Dimensões avaliadas no IPEA \\
\hline 1.Aspectos Tangíveis: & $\begin{array}{l}\text { Dispõe de equipamentos modernos; Instalações } \\
\text { físicas adequadas; empregados com boa } \\
\text { apresentação; aparência das instalações de } \\
\text { acordo com o serviço oferecido. }\end{array}$ & Infraestrutura física e tecnológica \\
\hline 2. Serviços (Intangíveis): & $\begin{array}{l}\text { Não há uma definição clara dessa dimensão na } \\
\text { tabela SERVQUAL. Essa é uma adaptação para } \\
\text { melhor compreensão das atividades finalísticas } \\
\text { do IPEA }\end{array}$ & $\begin{array}{c}\text { Qualidade dos serviços prestados } \\
\text { pelo IPEA }\end{array}$ \\
\hline 3.Confiabilidade: & $\begin{array}{l}\text { Cumprimento de prazos conforme prometido; } \\
\text { solução de problema de forma solidária com o } \\
\text { cliente; tem confiabilidade; fornece o serviço } \\
\text { em tempo prometido; mantém seus registros de } \\
\text { forma correta. }\end{array}$ & $\begin{array}{c}\text { Imagem e comunicação; } \\
\text { Estudos e pesquisas, bases de dados } \\
\text { e seminários }\end{array}$ \\
\hline $\begin{array}{l}\text { 4.Capacidade de } \\
\text { Resposta: }\end{array}$ & $\begin{array}{l}\text { Informa exatamente quando os serviços são } \\
\text { executados; recebe serviço de imediato; } \\
\text { funcionários estão sempre dispostos a ajudar os } \\
\text { clientes; funcionários não estão sempre } \\
\text { ocupados para responder aos pedidos dos } \\
\text { clientes. }\end{array}$ & Corpo técnico e administrativo \\
\hline 5.Segurança: & $\begin{array}{l}\text { Funcionários são confiáveis; o sentimento de se } \\
\text { sentir seguro em negociar com os funcionários } \\
\text { da empresa; funcionários são educados; suporte } \\
\text { adequado da empresa para cumprir suas tarefas } \\
\text { corretamente. }\end{array}$ & $\begin{array}{l}\text { Gestão e disseminação do } \\
\text { conhecimento }\end{array}$ \\
\hline 6.Empatia: & $\begin{array}{l}\text { Atenção individual; funcionários dão a você } \\
\text { atenção individual; funcionários sabem das suas } \\
\text { necessidades; os objetivos da empresa são seus } \\
\text { objetivos; horário de trabalho conveniente. }\end{array}$ & Planejamento e processo decisório \\
\hline
\end{tabular}

Fonte: Plano estratégico do IPEA 2013-2023 (2014) e Parasuraman at al., (1985)

\section{INSTRUMENTO DE AVALIAÇÃO DA QUALIDADE DOS SERVIÇOS}

\subsection{METODO SERVQUAL}

O instrumento SERVQUAL criado por Zeithaml, Parasuraman e Berry (2014) é composto por cinco dimensões de qualidade (aspectos tangíveis, confiabilidade, capacidade 
de resposta, segurança, empatia), e sua mensuração pode ser feita utilizando uma escala de 22 afirmações para verificar o que os clientes esperam de um serviço e 22 afirmações para medir a avaliação do cliente sobre uma prestação de serviço onde essa pesquisa constitui uma representação concisa dos critérios básicos que os clientes utilizam para avaliar a qualidade de um serviço.

A proposta da pesquisa é encontrar a diferença entre os escores de percepção e os de expectativa para determinar a mensuração da qualidade do serviço percebida pelo cliente. Logo, se a expectativa do serviço for superior à percepção, a qualidade percebida pelo usuário estará abaixo do grau esperado, ou seja, a diferença será negativa, e para que a diferença seja positiva a percepção deve ser maior que à expectativa, o que indica uma qualidade acima do esperado (JOHNSTON E CLARK, 2002).

Figura 7-Modelo Conceitual de Qualidade em Serviço

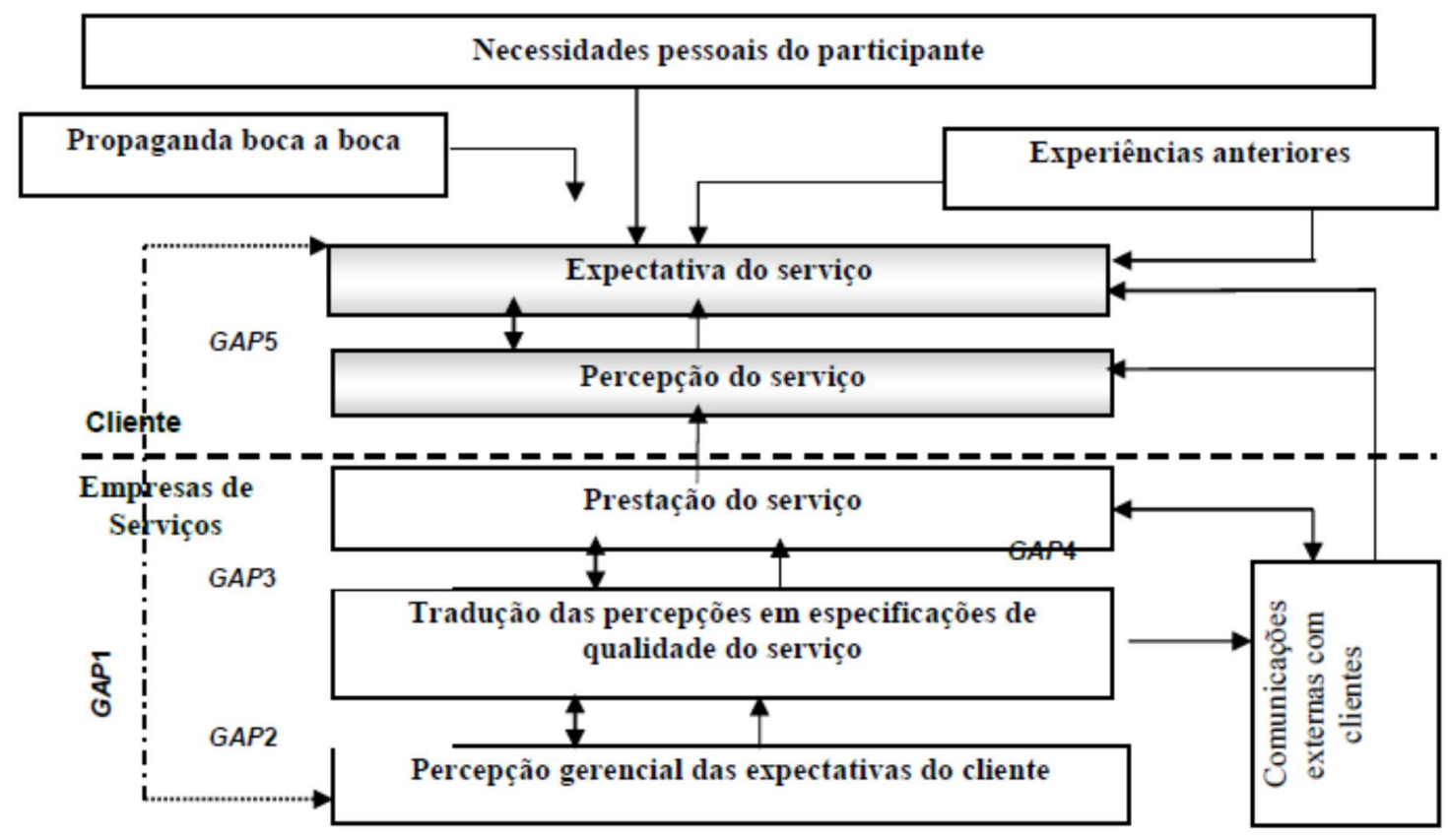

Fonte: (GAIO et al., 2012) apud Parasuraman, Zeithaml e Berry (1988, p. 44)

Os Gaps representados na figura 2 representam a diferença entre a expectativa e a percepção do cliente. Essas dimensões de qualidade seriam características genéricas do serviço subdividida em itens que somadas resultariam no serviço como um todo sob o ponto de vista do cliente que irá julga-lo. 
Augusto (2004) define Gaps como:

Gap 1 - Lacuna no conhecimento, ou a diferença entre o que os fornecedores de serviço acreditam que os clientes esperam e as reais necessidades e expectativas dos clientes. Vários fatores influenciam este gap:

i. A orientação à pesquisa de mercado demonstra a maneira como a empresa adquire informações sobre as expectativas dos consumidores. Acredita-se que, com o aumento destas pesquisas o gap do conhecimento tende a diminuir;

ii. A comunicação ascendente diz respeito ao fluxo de informações do pessoal de base da organização para alta administração. $\mathrm{O}$ pessoal de base possui um contato direto com os clientes, transmitindo assim, informações importantes para a gerência;

iii.Com relação aos níveis organizacionais, quanto mais hierárquicas for a organização, mais complexa torna-se a comunicação. Pois ocorrerá uma distância entre os consumidores e a administração, deixando de receber informações sobre o dia a dia das atividades.

Gap 2 - Lacuna na padronização ou a diferença apurada entre as percepções da gerência sobre as expectativas do cliente e os padrões de qualidade estabelecidos para a execução dos serviços. Existem algumas variáveis que influenciam este gap:

i. O "não" comprometimento da administração com a qualidade do serviço gera a falta de liderança, a não fixação de padrões para a qualidade e a ausência de programas que elevam os serviços e recompensam aqueles que se responsabilizam pela qualidade;

ii. As organizações que possuem programas de entrega de serviço de qualidade são notadas por fixarem metas formais. A elaboração de tais metas envolve conceituar a qualidade de serviços, de maneira que os provedores possam entender o que a administração quer entregar em seus serviços.

iii. A padronização tecnológica e dos comportamentos dos funcionários permite que as tarefas possam ser estabelecidas e efetivamente executadas, reduzindo assim o gap existente.

Gap 3 - Lacuna na entrega ou execução, que é a diferença entre aquilo que foi descrito nas especificações dos serviços pelos gerentes e a prestação efetiva dos serviços para os clientes, podendo ser influenciado pelos seguintes fatores:

i. As várias características do grupo podem modificar a qualidade dos serviços, como a motivação para desempenhar funções, o contato pessoal entre os envolvidos e comprometimento, dentre outros; 
ii. A adequação do pessoal e de tecnologia, podendo, porém, ocorrer que o funcionário não seja capacitado ou não tenha recebido treinamento suficiente para realizar suas funções. Da mesma maneira, pode ocorrer uma redução na qualidade do serviço, caso não exista equipamento apropriado e de confiança;

iii. Caso não ocorra a dispersão de controle, os funcionários podem tornar-se incapazes de resolver certos problemas ao retirar dos mesmos o controle sobre a natureza dos serviços oferecidos.

Gap 4 - Lacuna da comunicação ou a diferença entre a qualidade do que é entregue aos clientes e a que é transmitida aos clientes via publicidade e propaganda. Caso a empresa não cumpra o que é prometido, pode perder a confiança dos consumidores. Este gap pode ser influenciado pelas seguintes variáveis:

i. A comunicação horizontal tem como propósito coordenar pessoas e departamentos, de maneira que as metas da organização sejam executadas. A comunicação horizontal é necessária quando se deseja que os clientes percebam a qualidade no serviço realizado.

ii. A propensão à sobre promessa, é causada pelo fato de muitas empresas se sentirem pressionadas, prometendo mais do que podem cumprir, devido a intensificação da competição no setor de serviços.

Gap 5 - Lacuna nas percepções ou gap do consumidor, definida como a diferença entre a expectativa dos consumidores em relação ao serviço e o que foi realmente oferecido. Este gap depende do tamanho e direção dos quatro gaps anteriores, que estão relacionados à entrega do serviço por parte da empresa. O resultado da diferença entre as expectativas e percepções dos clientes com relação a qualidade do serviço prestado foi considerada pelos autores do modelo dos gaps, a principal causa na deficiência do serviço.

Quadro 5-Determinantes originais da qualidade

\begin{tabular}{|l|l|}
\hline DETERMINANTE & \multicolumn{1}{c|}{ CONCEITO } \\
\hline Confiabilidade & $\begin{array}{l}\text { Abrange consistência de desempenho e confiabilidade. Também significa que a } \\
\text { empresa honra seus compromissos. Especificamente envolve: precisão nas contas, } \\
\text { manutenção dos registros de forma correta e realização do serviço no tempo } \\
\text { designado. }\end{array}$ \\
\hline Presteza & $\begin{array}{l}\text { Refere-se ao desejo e presteza que os empregados têm em prover os serviços. } \\
\text { Envolve rapidez nos serviços, por exemplo: postar um recibo ou contatar um cliente } \\
\text { rapidamente, ou realizar rapidamente um serviço. }\end{array}$ \\
\hline
\end{tabular}




\begin{tabular}{|c|c|}
\hline Competência & $\begin{array}{l}\text { Significa possuir as habilidades necessárias e conhecimento para realizar o serviço, } \\
\text { envolvendo: conhecimento e habilidade do pessoal de atendimento, conhecimento e } \\
\text { habilidade do pessoal de apoio operacional, capacidade de pesquisa da organização. }\end{array}$ \\
\hline Acessibilidade & $\begin{array}{l}\text { Refere-se a proximidade e a facilidade de contato, significando que: o serviço pode } \\
\text { ser acessível por telefone, o tempo de espera para receber o serviço não é muito } \\
\text { extenso, tem um horário de funcionamento e localização conveniente. }\end{array}$ \\
\hline Cortesia & $\begin{array}{l}\text { Abrange educação, respeito, consideração e amabilidade do pessoal de atendimento. } \\
\text { Compreende também consideração com a propriedade do cliente (por exemplo: não } \\
\text { usar sapatos sujos no carpete). }\end{array}$ \\
\hline Comunicação & $\begin{array}{l}\text { Significa manter os clientes informados em linguagem que sejam capazes de } \\
\text { compreender. Pode significar que a companhia deve ajustar sua linguagem para } \\
\text { diferentes consumidores, aumentando o nível e sofisticação para os mais bem- } \\
\text { educados e conversando de maneira simples e direta com os mais simples. Também } \\
\text { compreende: proporcionar explicação do serviço, preços, descontos e garantir ao } \\
\text { consumidor que um eventual problema será resolvido. }\end{array}$ \\
\hline Credibilidade & $\begin{array}{l}\text { Considera a honestidade e implica em que a empresa esteja comprometida em atender } \\
\text { aos interesses e objetivos dos clientes, abrange: nome e reputação da empresa, } \\
\text { características pessoais dos atendentes e nível de interação com os clientes durante a } \\
\text { venda. }\end{array}$ \\
\hline Segurança & $\begin{array}{l}\text { Ausência de perigo, risco ou dúvidas, abrangendo: segurança física, financeira e } \\
\text { confidencialidade. }\end{array}$ \\
\hline $\begin{array}{l}\text { Compreensão e } \\
\text { conhecimento do } \\
\text { cliente }\end{array}$ & $\begin{array}{l}\text { Significa esforçar-se para compreender as necessidades dos clientes, envolvendo: } \\
\text { aprendizado sobre os requisitos específicos do cliente, proporcionar atenção } \\
\text { individualizada, reconhecer clientes constantes e preferenciais. }\end{array}$ \\
\hline Aspectos tangíveis & $\begin{array}{l}\text { Significa a inclusão e demonstração de evidências físicas ao serviço, tais como } \\
\text { instalações, aparência do pessoal, ferramentas e equipamentos utilizados no serviço, } \\
\text { representação física do serviço, tais como um cartão de crédito plástico, ou uma } \\
\text { prestação de contas, além de outros clientes presentes nas instalações }\end{array}$ \\
\hline
\end{tabular}

Fonte: (PARASURAMAN at al., 1985)

Como mostrado no quadro 5 , as determinantes da qualidade dos serviços são em número de 10, enquanto que as dimensões da escala SERVQUAL são em número de 5. Este comparativo é importante em razão das informações apresentadas na pesquisa do IPEA.

Apesar da possibilidade abrangência maior dos itens serviços nas dimensões originais, fizemos questão de dar destaque a itens específicos aos serviços (intangíveis) fornecidos pelo IPEA na avaliação visando a avaliação da instituição como um todo. 
Quadro 6-adaptação do modelo SERVQUAL

\begin{tabular}{|c|c|c|c|}
\hline \multicolumn{2}{|r|}{ DIMENSÕES ORIGINAIS } & \multicolumn{2}{|r|}{ DIMENSÕES ATUAIS SERVQUAL } \\
\hline 1 & Aspectos tangíveis & 1 & Aspectos tangíveis \\
\hline 2 & Confiabilidade & 2 & Confiabilidade \\
\hline 3 & Presteza & 3 & Capacidade de Resposta \\
\hline 4 & Competência & \multirow{4}{*}{4} & \multirow{4}{*}{ Segurança } \\
\hline 5 & Cortesia & & \\
\hline 6 & Credibilidade & & \\
\hline 7 & Segurança & & \\
\hline 8 & Acessibilidade & \multirow{2}{*}{5} & \multirow{2}{*}{ Empatia } \\
\hline 9 & Comunicação & & \\
\hline 10 & Compreensão/conhecimento do cliente & 6 & Serviços (intangíveis) \\
\hline
\end{tabular}

Fonte: (PARASURAMAN at al., 1985)

Aplicando os conceitos referentes ao tópico anterior, podemos construir um instrumento de avaliação, um questionário, referente à expectativa que o cliente tem na utilização dos serviços oferecidos pelo IPEA. Com o propósito de dar mais confiança aos dados da pesquisa utilizaremos uma escala de Likert de sete pontos. O grau de importância da escala Likert é representado por:

Quadro 7-Questionários respectivos à expectativa e a percepção para mensurar a Qualidade do serviço

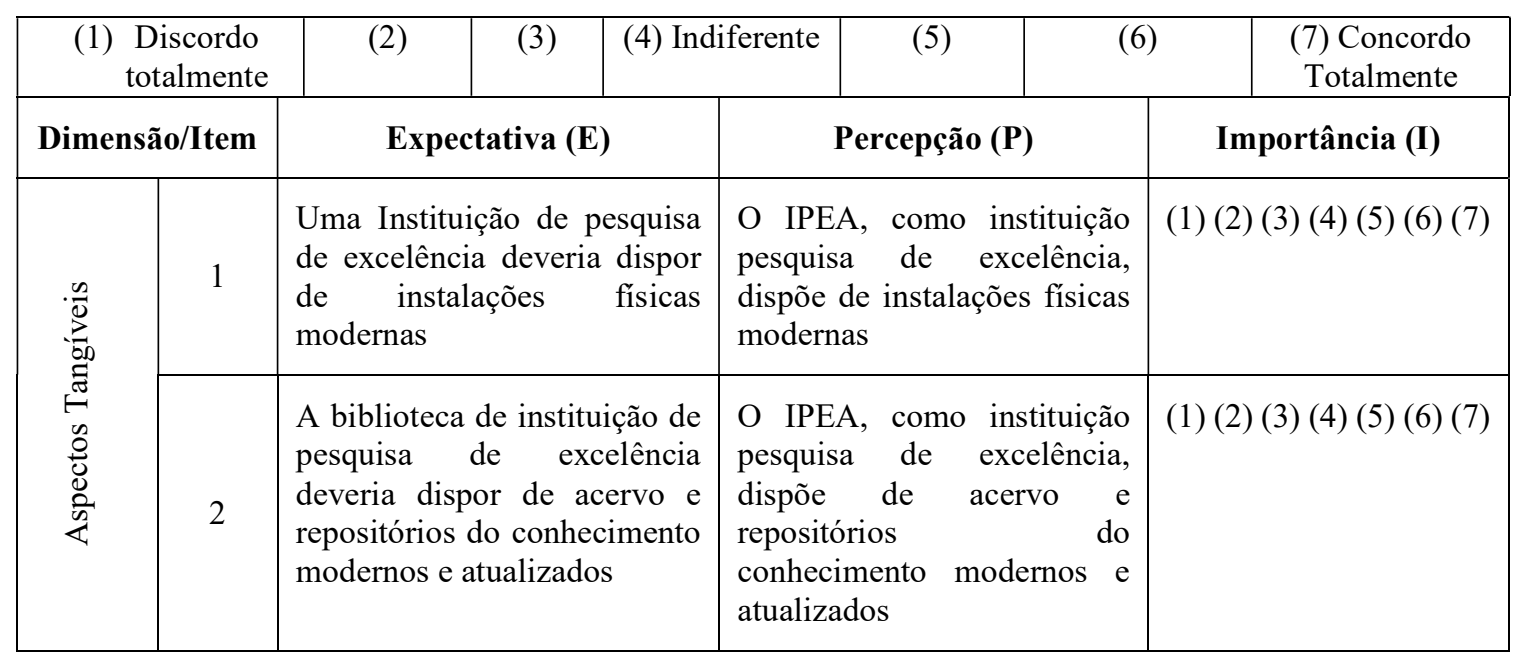




\begin{tabular}{|c|c|c|c|c|}
\hline & 3 & $\begin{array}{l}\text { Uma Instituição de pesquisa } \\
\text { de excelência deveria Dispor } \\
\text { de equipamentos de } \\
\text { informática modernos e base } \\
\text { de dados atualizada }\end{array}$ & $\begin{array}{l}\text { O IPEA, como instituição } \\
\text { pesquisa de excelência, } \\
\text { dispõe de equipamentos de } \\
\text { informática modernos e base } \\
\text { de dados atualizada }\end{array}$ & $(1)(2)(3)(4)(5)(6)(7)$ \\
\hline & 4 & $\begin{array}{l}\text { Os servidores de uma } \\
\text { instituição de pesquisa de } \\
\text { excelência deveriam ter boa } \\
\text { apresentação }\end{array}$ & $\begin{array}{l}\text { Os servidores do IPEA, } \\
\text { como instituição pesquisa de } \\
\text { excelência, têm boa } \\
\text { apresentação }\end{array}$ & $(1)(2)(3)(4)(5)(6)(7)$ \\
\hline \multirow{6}{*}{ 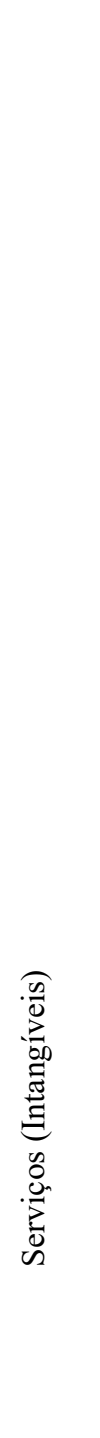 } & 5 & $\begin{array}{l}\text { Uma instituição de pesquisa } \\
\text { de excelência deveria ter sua } \\
\text { área de atuação bem } \\
\text { delimitada }\end{array}$ & $\begin{array}{l}\text { O IPEA, como instituição } \\
\text { pesquisa de excelência, tem } \\
\text { sua área de atuação bem } \\
\text { delimitada }\end{array}$ & $(1)(2)(3)(4)(5)(6)(7)$ \\
\hline & 6 & $\begin{array}{l}\text { Uma instituição de pesquisa } \\
\text { de excelência deveria } \\
\text { apresentar seus trabalhos de } \\
\text { forma a atender as } \\
\text { necessidades dos usuários }\end{array}$ & $\begin{array}{l}\text { O IPEA, como instituição } \\
\text { pesquisa de excelência, } \\
\text { apresenta seus trabalhos de } \\
\text { forma a atender as } \\
\text { necessidades dos usuários }\end{array}$ & $(1)(2)(3)(4)(5)(6)(7)$ \\
\hline & 7 & $\begin{array}{l}\text { Os trabalhos desenvolvidos } \\
\text { por uma instituição de } \\
\text { pesquisa de excelência } \\
\text { deveriam influenciar bastante } \\
\text { nas tomadas de decisões }\end{array}$ & $\begin{array}{l}\text { Os trabalhos desenvolvidos } \\
\text { pelo IPEA, como instituição } \\
\text { pesquisa de excelência, } \\
\text { influenciam bastante nas } \\
\text { tomadas de decisões }\end{array}$ & $(1)(2)(3)(4)(5)(6)(7)$ \\
\hline & 8 & $\begin{array}{l}\text { Uma instituição pública de } \\
\text { pesquisa de excelência } \\
\text { deveria contribuir muito com } \\
\text { melhoria na qualidade das } \\
\text { decisões do Governo Central }\end{array}$ & $\begin{array}{l}\text { O IPEA, como instituição } \\
\text { pública de pesquisa de } \\
\text { excelência, contribui muito } \\
\text { com melhoria na qualidade } \\
\text { das decisões do Governo } \\
\text { Central }\end{array}$ & $(1)(2)(3)(4)(5)(6)(7)$ \\
\hline & 9 & 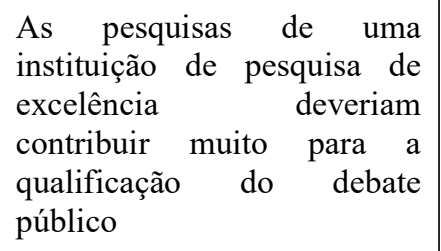 & $\begin{array}{l}\text { As pesquisas do IPEA, como } \\
\text { instituição de pesquisa de } \\
\text { excelência, contribuem } \\
\text { muito para a qualificação do } \\
\text { debate público }\end{array}$ & $(1)(2)(3)(4)(5)(6)(7)$ \\
\hline & 10 & $\begin{array}{l}\text { Os serviços prestados por uma } \\
\text { instituição pública de } \\
\text { pesquisa deveriam atender o } \\
\text { interesse público }\end{array}$ & $\begin{array}{l}\text { Os serviços prestados pelo } \\
\text { IPEA, como instituição } \\
\text { pública de pesquisa de } \\
\text { excelência, atendem } \\
\text { interesse público }\end{array}$ & $(1)(2)(3)(4)(5)(6)(7)$ \\
\hline 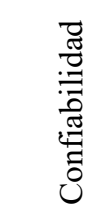 & 11 & $\begin{array}{l}\text { Os serviços prestados por uma } \\
\text { instituição de pesquisa de } \\
\text { excelência deveriam atender } \\
\text { aos usuários (interno e } \\
\text { externo) conforme prometido }\end{array}$ & $\begin{array}{l}\text { Os serviços prestados pelo } \\
\text { IPEA, como instituição } \\
\text { pesquisa de excelência, } \\
\text { atendem aos usuários } \\
\text { conforme prometido }\end{array}$ & $(1)(2)(3)(4)(5)(6)(7)$ \\
\hline
\end{tabular}




\begin{tabular}{|c|c|c|c|c|}
\hline & 12 & $\begin{array}{l}\text { Os serviços prestados por uma } \\
\text { instituição de pesquisa de } \\
\text { excelência deveriam ser } \\
\text { concluídos dentro do prazo } \\
\text { previsto }\end{array}$ & $\begin{array}{l}\text { Os serviços prestados pelo } \\
\text { IPEA, como instituição } \\
\text { pesquisa de excelência, são } \\
\text { concluídos dentro do prazo } \\
\text { previsto }\end{array}$ & $(1)(2)(3)(4)(5)(6)(7)$ \\
\hline & 13 & $\begin{array}{l}\text { Os usuários de uma } \\
\text { instituição de pesquisa de } \\
\text { excelência deveriam ser } \\
\text { informados sobre os prazos } \\
\text { para realização dos serviços }\end{array}$ & $\begin{array}{l}\text { Os usuários do IPEA, como } \\
\text { instituição de pesquisa de } \\
\text { excelência, são informados } \\
\text { sobre os prazos para } \\
\text { realização dos serviços }\end{array}$ & $(1)(2)(3)(4)(5)(6)(7)$ \\
\hline \multirow{3}{*}{ 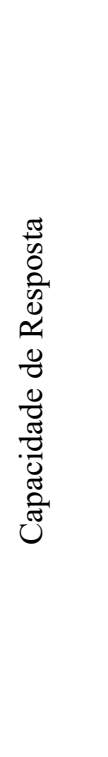 } & 14 & $\begin{array}{l}\text { Em uma instituição de } \\
\text { pesquisa de excelência } \\
\text { deveria ser ágil na solução dos } \\
\text { problemas dos usuários } \\
\text { (interno e externo) }\end{array}$ & $\begin{array}{l}\text { O IPEA, como instituição de } \\
\text { pesquisa de excelência, é ágil } \\
\text { na solução dos problemas } \\
\text { dos usuários (interno e } \\
\text { externo) }\end{array}$ & $(1)(2)(3)(4)(5)(6)(7)$ \\
\hline & 15 & $\begin{array}{l}\text { Em uma instituição de } \\
\text { pesquisa de excelência } \\
\text { deveria haver mais } \\
\text { disponibilidade por parte dos } \\
\text { servidores para atender os } \\
\text { usuários }\end{array}$ & $\begin{array}{l}\text { No IPEA, como instituição } \\
\text { pesquisa de excelência, há } \\
\text { mais disponibilidade por } \\
\text { parte dos servidores para } \\
\text { atender os usuários }\end{array}$ & $(1)(2)(3)(4)(5)(6)(7)$ \\
\hline & 16 & $\begin{array}{l}\text { Em uma instituição de } \\
\text { pesquisa de excelência os } \\
\text { servidores deveriam oferecer } \\
\text { mais de uma solução para o } \\
\text { mesmo serviço contratado }\end{array}$ & $\begin{array}{l}\text { No IPEA, como uma } \\
\text { instituição de pesquisa de } \\
\text { excelência, os servidores } \\
\text { oferecem mais de uma } \\
\text { solução para o mesmo } \\
\text { serviço contratado }\end{array}$ & $(1)(2)(3)(4)(5)(6)(7)$ \\
\hline \multirow[b]{3}{*}{ 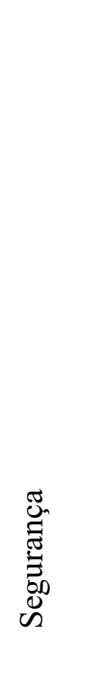 } & 17 & $\begin{array}{l}\text { Os servidores de uma } \\
\text { instituição pública de } \\
\text { excelência deveriam possuir } \\
\text { conhecimento amplo nas } \\
\text { áreas que atuam }\end{array}$ & 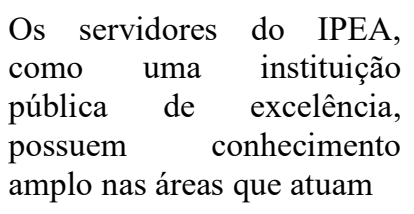 & $(1)(2)(3)(4)(5)(6)(7)$ \\
\hline & 18 & $\begin{array}{l}\text { As dúvidas dos usuários } \\
\text { deveriam ser sanadas } \\
\text { integralmente por uma } \\
\text { instituição de pesquisa de } \\
\text { excelência }\end{array}$ & $\begin{array}{l}\text { As dúvidas dos usuários são } \\
\text { sanadas integralmente pelo } \\
\text { IPEA, como uma instituição } \\
\text { de pesquisa de excelência }\end{array}$ & $(1)(2)(3)(4)(5)(6)(7)$ \\
\hline & 19 & $\begin{array}{l}\text { As informações passadas } \\
\text { pelos servidores de uma } \\
\text { instituição de pesquisa de } \\
\text { excelência deveriam ser } \\
\text { precisas e corretas }\end{array}$ & $\begin{array}{l}\text { As informações passadas } \\
\text { pelos servidores do IPEA, } \\
\text { como uma instituição de } \\
\text { pesquisa de excelência, são } \\
\text { precisas e corretas }\end{array}$ & $(1)(2)(3)(4)(5)(6)(7)$ \\
\hline : & 20 & $\begin{array}{l}\text { Os usuários deveriam receber } \\
\text { atendimento personalizado } \\
\text { pelos servidores de uma }\end{array}$ & $\begin{array}{l}\text { Os usuários recebem } \\
\text { atendimento personalizado } \\
\text { pelos servidores do IPEA, }\end{array}$ & $(1)(2)(3)(4)(5)(6)(7)$ \\
\hline
\end{tabular}




\begin{tabular}{|c|l|l|l|l|}
\hline & $\begin{array}{l}\text { instituição de pesquisa de } \\
\text { excelência }\end{array}$ & $\begin{array}{l}\text { como uma instituição de } \\
\text { pesquisa de excelência }\end{array}$ & \\
\hline 21 & $\begin{array}{l}\text { Os usuários deveriam ser } \\
\text { tratados de maneira atenciosa } \\
\text { pelos servidores de uma } \\
\text { instituição de pesquisa de } \\
\text { excelência }\end{array}$ & $\begin{array}{l}\text { Os usuários são tratados de } \\
\text { maneira atenciosa pelos } \\
\text { servidores do IPEA, como } \\
\text { uma instituição de pesquisa } \\
\text { de excelência }\end{array}$ & (1) (2) (3) (4) (5) (6) (7) \\
\hline 22 & $\begin{array}{l}\text { Os servidores de uma } \\
\text { instituição de pesquisa de } \\
\text { excelência deveriam } \\
\text { demonstrar interesse em } \\
\text { solucionar os problemas dos } \\
\text { usuários (7) (5) (6) (7) }\end{array}$ & $\begin{array}{l}\text { Os servidores do IPEA, } \\
\text { como uma instituição de } \\
\text { pesquisa de excelência, } \\
\text { demonstram interesse em } \\
\text { solucionar os problemas dos } \\
\text { usuários }\end{array}$ & (1) (2) (4) \\
\hline
\end{tabular}

Fonte: elaboração própria com adaptações da escala SERVQUAL (PARASURAMAN at al., 1985)

\subsubsection{Cálculo do Tamanho da Amostra}

A finalidade do IPEA, prevista no art. $2^{\circ}$ de seu estatuto, é "promover e realizar pesquisas e estudos sociais e econômicos e disseminar o conhecimento resultante, dar apoio técnico e institucional ao Governo na avaliação, formulação e acompanhamento de políticas públicas, planos e programas de desenvolvimento e oferecer à sociedade elementos para o conhecimento e solução de problemas e dos desafios do desenvolvimento brasileiro" $"$.

Nesse contexto, a instituição tem sua área de atuação definida dentro Governo como um todo. No entanto, as demandas principais giram em torno da Esplanada dos Ministérios, em Brasília, onde o público de interesse maior está inserido.

O público alvo desta pesquisa são gestores de serviços e servidores públicos ligados aos diversos órgãos públicos federais, instituições de pesquisa e universidades estabelecidas no Distrito Federal, local da sede do IPEA, e que aparecem com muita frequência nas parcerias com a instituição para realização de trabalhos. O público alvo dessas instituições parceiras representa um universo de “(125.775 $)^{9}$ servidores ativos, dentre os quais 77.442 servidores são do sexo

\footnotetext{
${ }^{8}$ Estatuto do IPEA. Fonte:

http://www.ipea.gov.br/portal/images/stories/PDFs/presi/100329 decreto7142 estatuto ipea.pdf.

${ }^{9}$ Dados levantados do Quadro de Pessoal do Governo Federal. Fonte: http://paineldoservidor.planejamento.gov.br/QvAJAXZfc/opendoc.htm?document=Boletim $\% 20$ Estatistico $\% 2$ $\underline{0 \text { de } \% 20 \text { Pessoal.qvw\&host }=\text { Local\&anonymous }=\text { true. }}$.
} 
masculino e 48.350 servidores do sexo feminino" distribuídos em $(26){ }^{10}$ ministérios, 10 secretarias e 23 conselhos.

Com isso, o questionário foi aplicado em Brasília no período de 16 a 22 de novembro de 2016, ao número de servidores proposto na amostra, ou seja, foi considerada uma população finita. Admitindo um intervalo de confiança de $90 \% \mathrm{e}$ uma margem de erro mínima de $10 \%$, logo temos as seguintes equações:

$$
n_{0}=\frac{1}{E_{0}^{2}} \text { e } n=\frac{N \cdot n_{0}}{N+n_{0}}
$$

Onde:

$\mathrm{n}=$ tamanho da amostra

$\mathrm{N}=$ tamanho da população

$E_{0}=$ erro estimado / tolerável para a pesquisa

$n_{0}=$ aproximação do tamanho da amostra

Para determinar a aproximação do tamanho da amostra temos: $E_{0=10 \%-0,1}$

$$
n_{0}=\frac{1}{E_{0}^{2}}=\frac{1}{0,1^{2}} \rightarrow n_{0}=100
$$

Para encontrar o tamanho da amostra utilizamos a seguinte expressão: $n=$ $\frac{N \cdot n_{0}}{N+n_{0}}$

Substituindo os valores de $\mathrm{N}$ pelo número total de servidores (125.775 servidores ativos) e aproximação do tamanho da amostra $\mathrm{n}_{0}=100$, na equação, temos:

$$
n=\frac{N * n_{0}}{N+n_{0}}=\frac{125.775 * 100}{125.775+100} \rightarrow n=99,92 \cong 100
$$

\footnotetext{
${ }^{10}$ Formação do Governo Federal.

Fonte: $\underline{\mathrm{http}} / / / \mathrm{www} \cdot$ brasil.gov.br/governo/2009/11/governo-federal-e-formado-por-ministerios-secretarias-eorgaos-especiais.
} 
A proposta inicial na definição da amostra seria enviar os formulários eletrônicos para vários órgãos públicos federais. No entanto, com a análise do Plano Estratégico já comentado neste trabalho ficou constado que dentro do próprio Governo Federal boa servidores não conhecem o IPEA e quais suas atribuições. Dessa forma resolvemos aplicar os questionários internamente dentro dos prazos definidos anteriormente.

\subsubsection{Aplicação do Alpha de Cronbach}

O coeficiente de Alpha de Cronbach é calculado a partir da variância dos itens individuais e da variância da soma dos itens de cada avaliador de todos os itens de um questionário que utilizem a mesma escala de medição.

$$
\propto=\left[\frac{k}{k-1}\right]\left[1-\frac{\sum_{k-1}^{n k} S_{i}^{2}}{S_{t}^{2}}\right]
$$

Em que:

- $S_{i}^{2}$ é a variância do item $i$;

- $S_{t}^{2}$ é a variância da soma dos itens observados ou a variância total do questionário;

- $\quad k$ é o número de perguntas ou itens do questionário.

O valor do Alpha de Cronbach varia entre 0 e 1. De acordo com Scramim; Rieg; Maia (2015) com citação de outros autores "embora este coeficiente seja largamente usado para medir a confiabilidade de um instrumento, ainda não há consenso na literatura acerca da interpretação dos seus valores (Hora et al., 2010). Freitas et Rodrigues (2005) sugerem a classificação da confiabilidade de um dado questionário, a partir do cálculo do coeficiente Alpha de Cronbach, de acordo com os limites apresentados" no quadro 8.

Quadro 8-Classificação da confiabilidade a partir do coeficiente de Alpha de Cronbach

\begin{tabular}{c|ccccc}
\hline Confiabilidade & Muito Baixa & Baixa & Moderada & Alta & Muito Alta \\
\hline Valor de $\alpha$ & $\alpha \leq 0,30$ & $0,30<\alpha \leq 0,60$ & $0,60<\alpha \leq 0,75$ & $0,75<\alpha \leq 0,90$ & $\alpha>0,90$ \\
\hline
\end{tabular}

Fonte: (SCRAMIM; RIEG; MAIA, 2015 apud Freitas et Rodrigues (2005, p.4) 


\section{ANALISE E DISCUSSÃO DOS RESULTADOS}

\subsection{COLETA DE DADOS PRIMÁRIOS}

Os dados primários foram obtidos por meio da aplicação de um questionário eletrônico dividido em duas etapas encaminhados para os e-mails dos usuários dentro da amostra definida anteriormente: a primeira etapa do questionário representa a avaliação da expectativa do usuário, tanto interno, quanto externo, tendo em vista a identificação das características principais que o IPEA precisa ter para desenvolver sua missão institucional. A segunda etapa do questionário representa a avaliação da percepção do usuário quanto aos mesmos critérios para avaliação da expectativa. $\mathrm{Na}$ análise, os dados foram transformados em medidas centrais e de dispersão, obtidos pela aplicação do SPSS.

Da amostra identificada em aproximadamente 100 usuários, foram atingidos 92,5\% no questionário respondido para a análise da expectativa; para o questionário que trata da percepção foram atingidos $66 \%$ de respostas dos usuários, isso quer dizer que nem todos os usuários que responderam o questionário de expectativa, responderam o questionário de percepção. Para descrição do perfil dos respondentes usaremos como base os $92,5 \%$ da amostra de expectativa.

O universo da amostra ficou restrito aos servidores, colaboradores e usuários que frequentam as instalações do IPEA em Brasília. De certo modo o resultado pode representar uma situação mais próxima da realidade uma vez que o público respondente tem mais familiaridade com os problemas internos e externos quando se trata de prestação de serviços a outras instituições públicas e privadas.

Quanto aos resultados obtidos na amostra em questão:

a) A classificação por gênero ficou em $60 \%$ da amostra para o sexo masculino e os outros $40 \%$ para o sexo feminino. 
Gráfico 4-Classificação da amostra por gênero

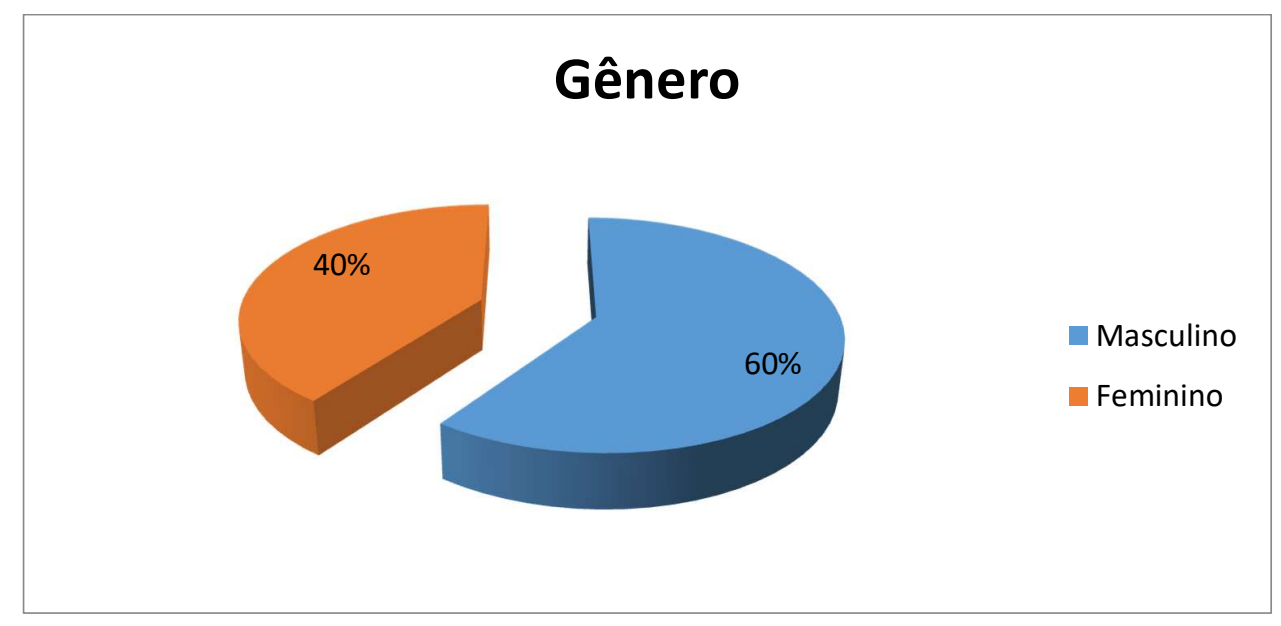

Fonte: Dados primários da pesquisa

b) A classificação da amostra por faixa etária ficou assim distribuída: de 18 a 28 anos foram $12 \%$ dos respondentes; de 29 a 38 anos foram $22 \%$ dos respondentes; de 39 a 48 anos foram 25\% dos respondentes; de 49 a 59 anos foram $27 \%$ dos respondentes; e acima de 59 anos foram $15 \%$ dos respondentes.

Gráfico 5-Classificação da amostra por idade

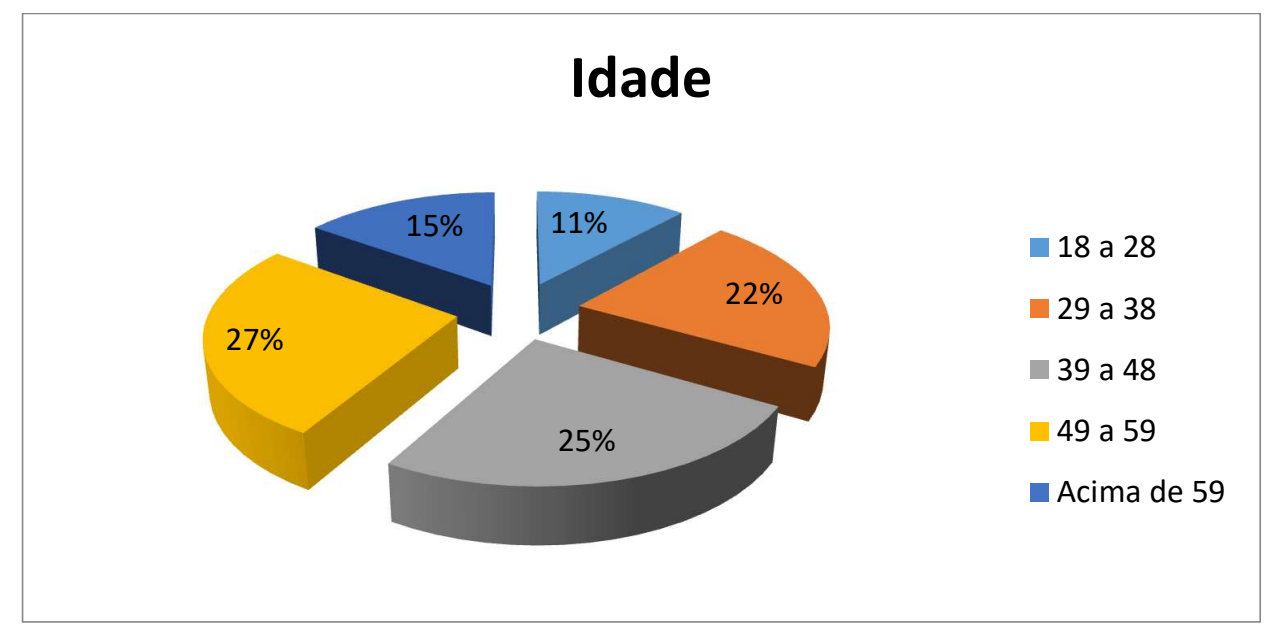

Fonte: Dados primários da pesquisa

c) A classificação da amostra por grau de instrução ficou assim distribuída: o nível médio atingiu somente 3\% do total de usuários entrevistados; o nível superior 
chegou a $40 \%$ dos entrevistados; o mestrado atingiu 27\% dos entrevistados; já o doutorado chegou a $30 \%$ dos entrevistados.

Gráfico 6-Classificação da amostra por grau de instrução

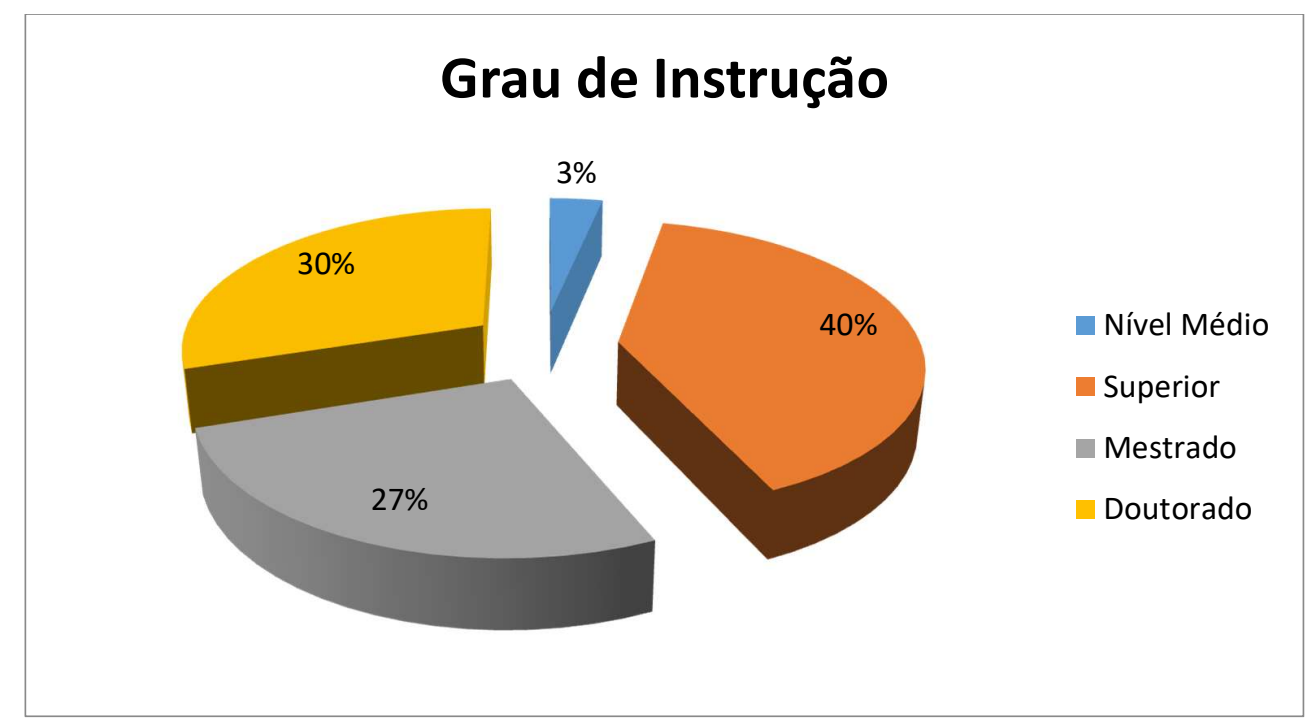

Fonte: Dados primários da pesquisa

d) A classificação da amostra por área de atuação ficou distribuído da seguinte forma: na área técnica foram $58 \%$ dos respondentes; na área administrativa foram $41 \%$ dos respondentes, enquanto que os usuários externos só foram $2 \%$ dos respondentes apesar de termos enviado os questionários para algumas instituições públicas e privadas.

Gráfico 7-Classificação da amostra área de atuação

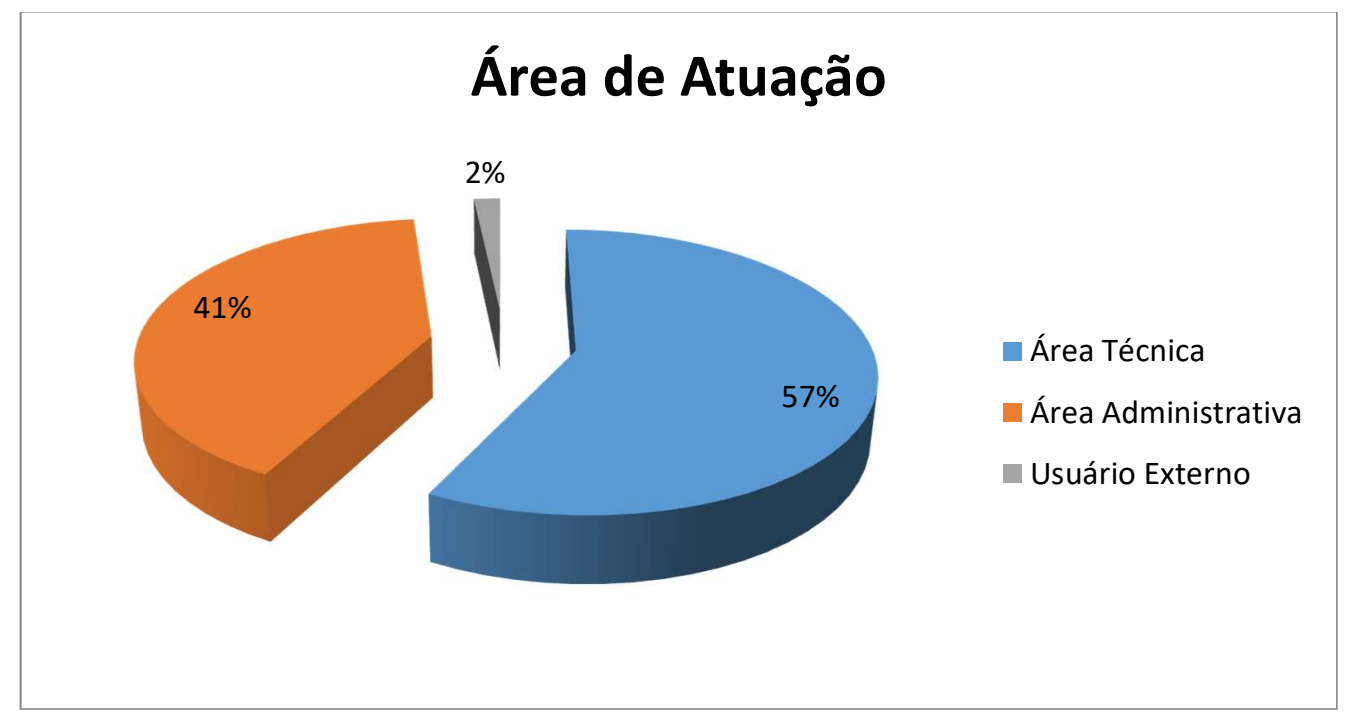


Fonte: Dados primários da pesquisa

\subsection{DISTRIBUIÇÃO PERCENTUAL DOS RESPONDENTES POR DIMENSÃO}

O percentual distribuído nas dimensões com base na escala de Likert que vai de 1 a 7 ficou assim distribuído: dentro dos aspectos tangíveis percebe-se que o usurário tem uma visão de que uma instituição de pesquisa de excelência deveria dispor de instalações físicas modernas, biblioteca com acervo e repositórios do conhecimento moderno e atualizado, equipamentos de informática e base de dados atualizados e servidores com boa aparência.

Deve-se destacar que a afirmativa que representa a questão da aparência dos servidores no que se refere a expectativa ficou mais ou menos indiferente, uma vez que $26,4 \%$ dos respondentes avaliaram no número 5 e outros $27,6 \%$ dos respondentes avaliaram no número 6. Quanto a percepção do usuário na mesma afirmativa o usuário achou que a afirmativa é indiferente para o bom desempenho das atividades.

Gráfico 8-Percentual médio dos respondentes em aspectos tangíveis

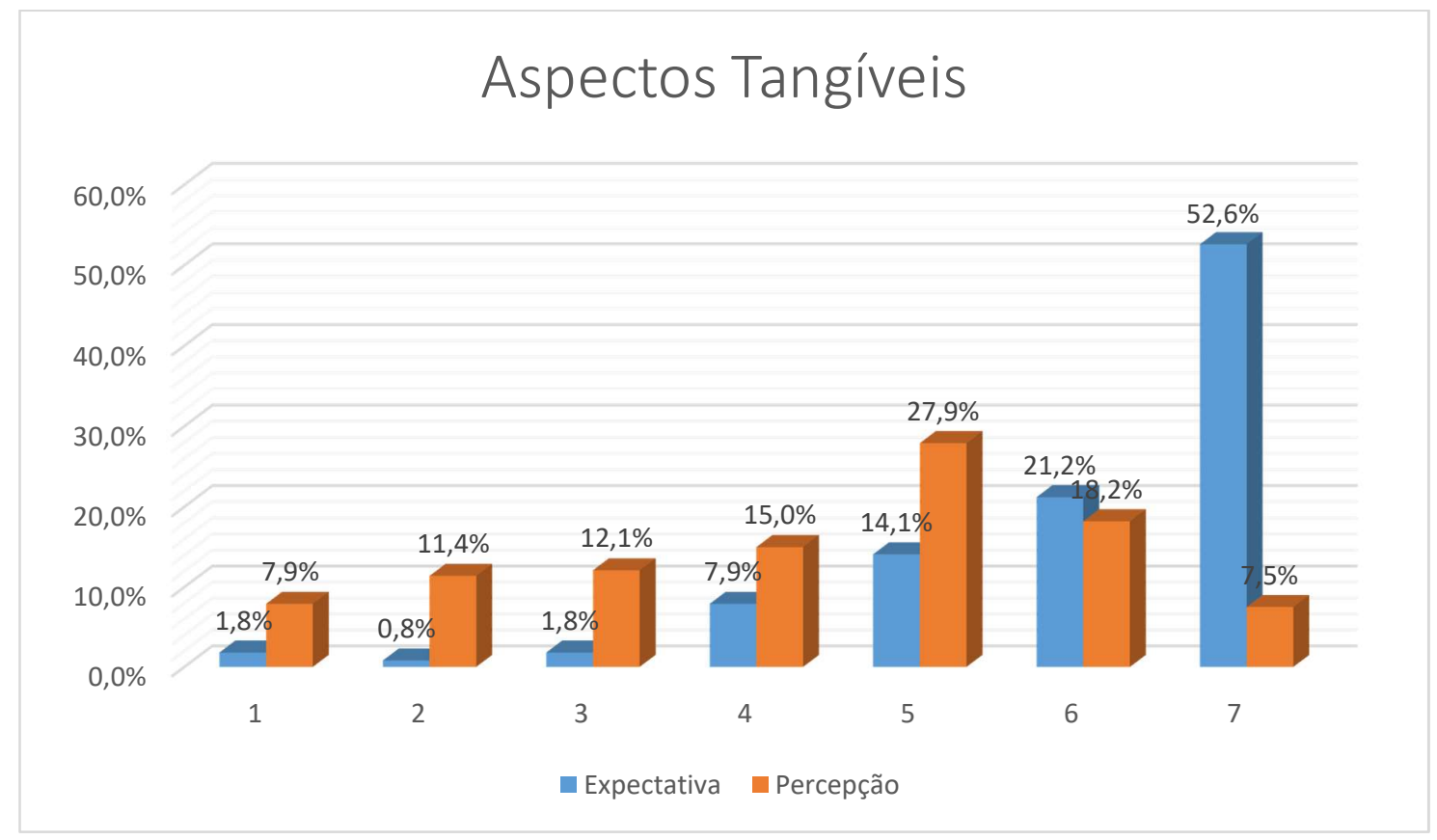

Fonte: Dados primários da pesquisa 
Quanto a dimensão serviços que trata de questões relativas a delimitação da área de atuação, apresentação dos trabalhos de forma a atender as necessidades do usuário, poder de influência nas tomadas de decisões de quem os contrata, contribuir mais nas tomadas de decisões do Governo Central, contribuir mais com o debate público além de fazer pesquisas com vistas a atender o interesse público, observase que o usuário espera muito do IPEA em todos as afirmativas. A média encontrada nesta dimensão foi de $51 \%$ dos respondentes votaram no número 7 da escala.

Quando se trata da percepção sobre as mesmas afirmativas 29,7\% dos respondentes votaram no número 5 e $20,7 \%$ dos respondentes votaram no número 6.

Gráfico 9-Percentual médio dos respondentes em serviços

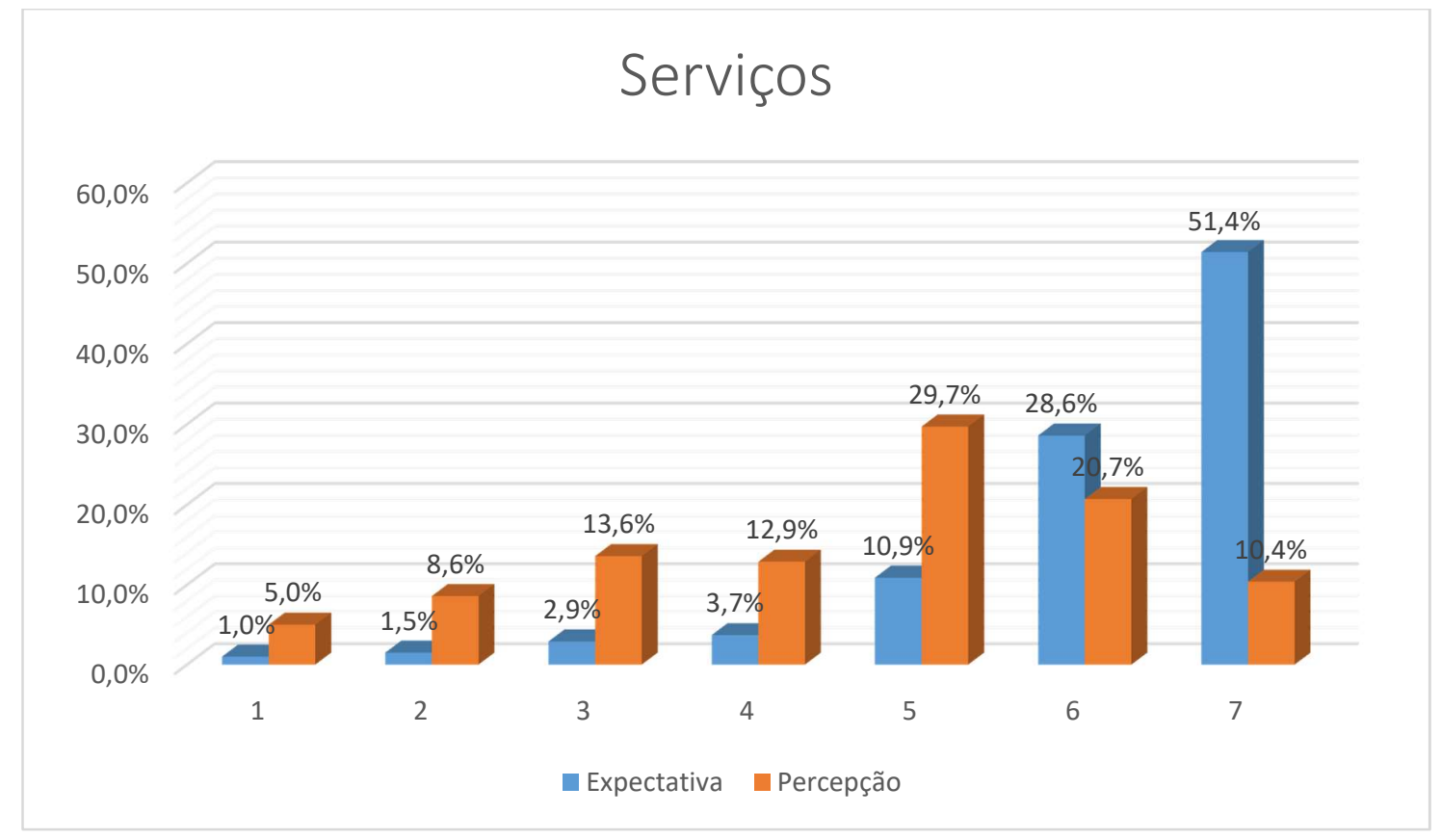

Fonte: Dados primários da pesquisa

Quanto a dimensão confiabilidade que trata da prestação dos serviços conforme prometido, dentro do prazo previsto e da clareza das informações a serem passadas ao usuário durante a realização dos serviços, os respondentes consideraram importante do ponto de vista da expectativa onde 46,3 deles votaram no número 7 enquanto que outros 33,7\% votaram no número 6 . 
Já a percepção que os usuários têm da mesma dimensão ficou em 26,7\% votaram no número 5 e outros $23,3 \%$ votaram no número 6 .

Gráfico 10-Percentual médio dos respondentes em confiabilidade

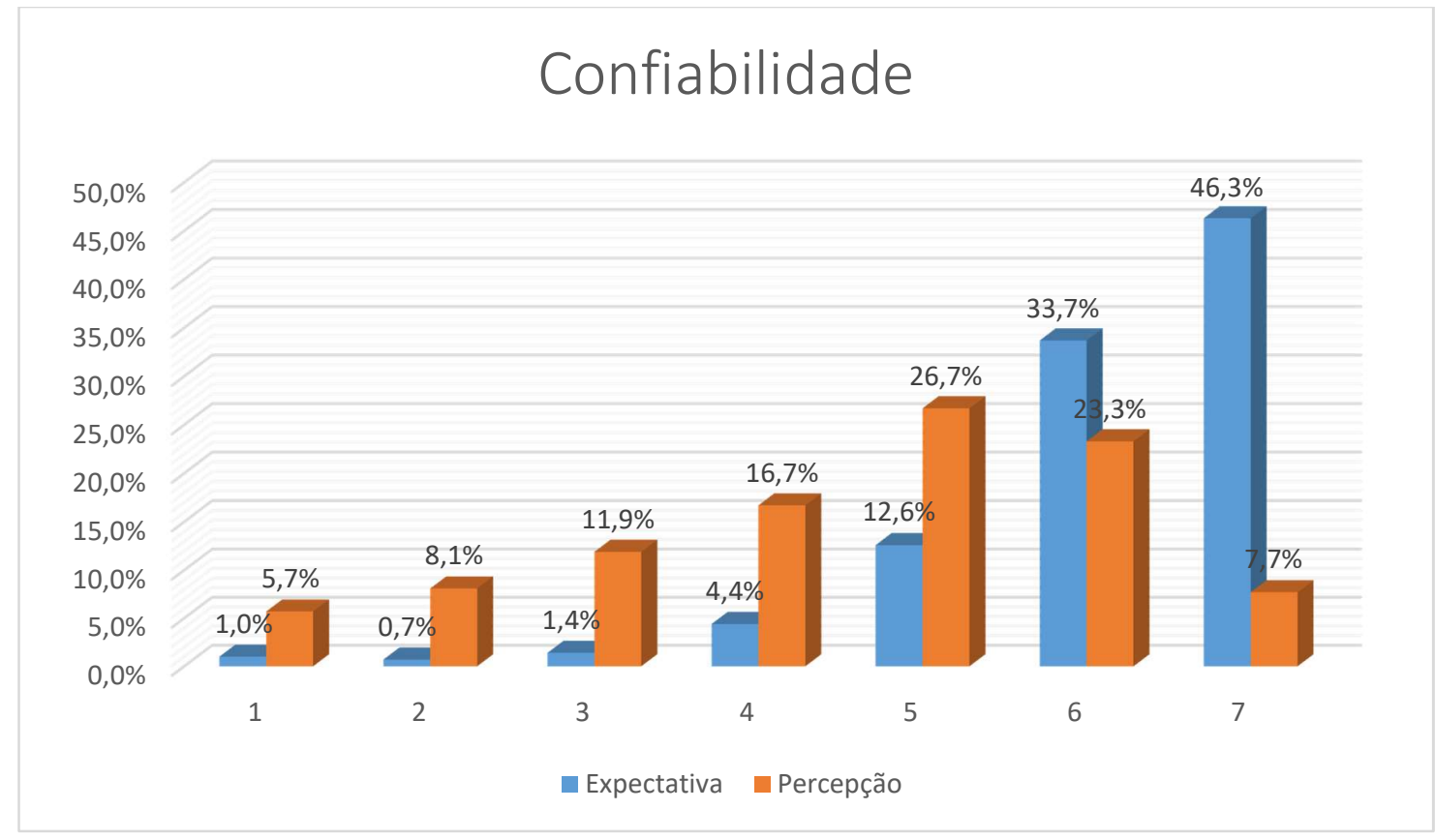

Fonte: Dados primários da pesquisa

A capacidade de resposta, que trata de: dar uma solução rápida aos problemas dos usuários; disponibilizar mais tempo por parte dos serviços para atenderem aos usuários; dar mais de uma alternativa para solução de um mesmo serviço contratado apresentou leitura dos votos um pouco pior do os itens anteriores. Atribui-se a isso a questão burocrática que ronda as instituições públicas como um todo, além do mais a afirmativa pode ter sido mal compreendida pelos os usuários.

A afirmativa que trata de dar mais de uma solução para um mesmo serviço contratado teve a distribuição dos votos fragmentada onde a maioria dos votos ficou nos números 4 com 19,3\%, 5 com 13,3\%, 6 com 28,6\% e o 7 com 26,4\%. 


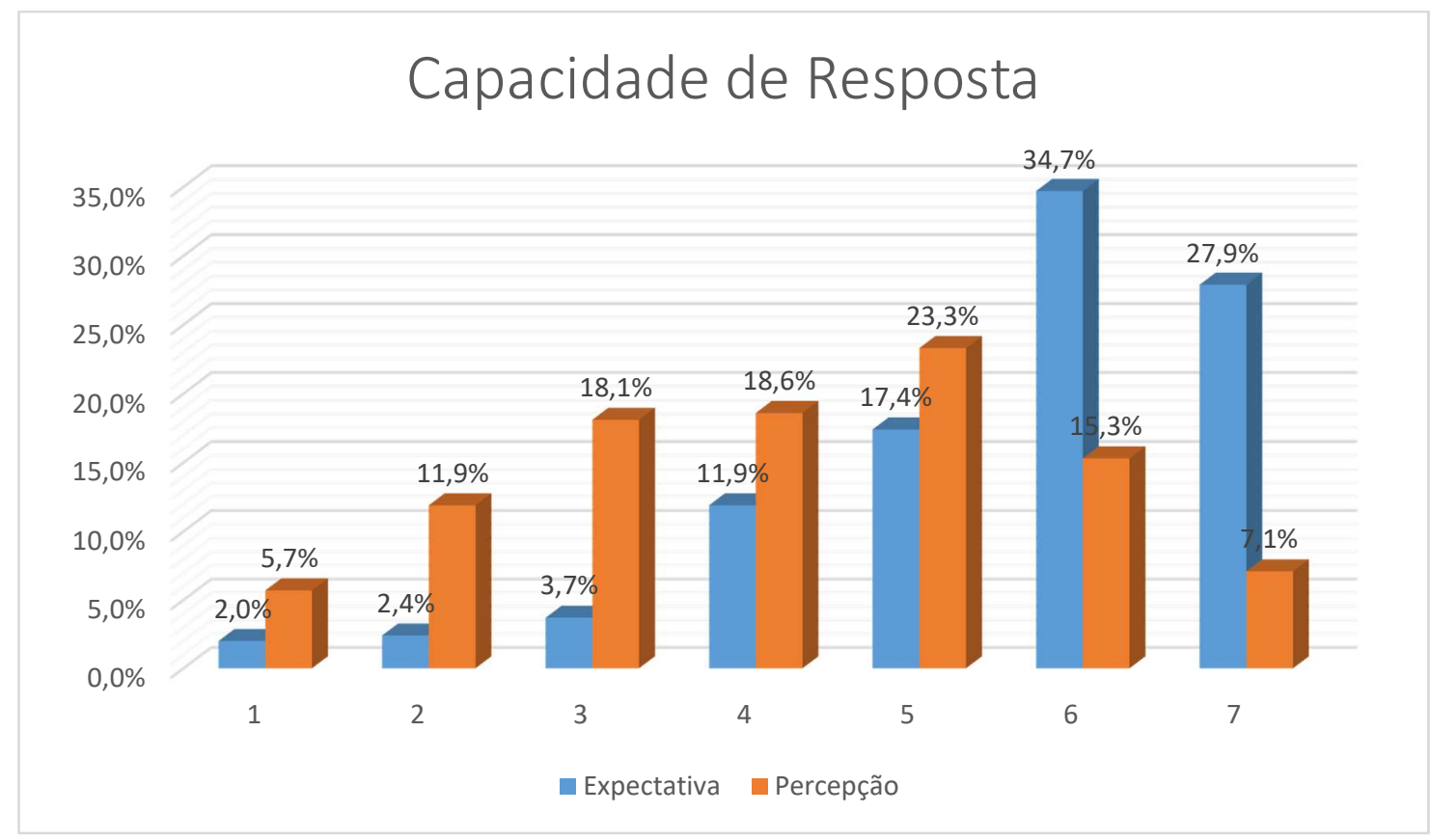

Fonte: Dados primários da pesquisa

$\mathrm{Na}$ dimensão segurança que trata da expectativa dos usuários quanto: ao conhecimento dos servidores nas áreas que atuam; a sanar integralmente as dúvidas dos usuários; a precisão das informações passadas pelos servidores aos usuários, o percentual médio de votos fícou concentrado no número 7 com 53,8\%. Já a percepção sobre o mesmo tema ficou com os votos no número 5 com $26,2 \%$ e número $6 \operatorname{com} 25,2 \%$.

Vale destacar nesta dimensão que a afirmativa que trata da expectativa dos servidores sanarem integralmente as dúvidas dos usuários, teve boa parte dos votos concentrados no número 5 com $35,7 \%$. O mesmo ocorreu com a percepção dos usuários ficou no número 5 com $25,7 \%$.

Podemos aqui fazer comparações com o setor privado como, por exemplo, um determinado serviço contratado que foi executado em uma residência. Ocorre que o contratante usufruir desse serviço será necessário o executante dar uma orientação quanto a obtenção do resultado esperado. Caso isso não ocorra, o executante não 
cumpriu o papel fundamental de sanar todas as dúvidas necessárias para o usuário. No setor público isso não pode e nem deve ser diferente do exemplo citado.

Gráfico 12-Percentual médio dos respondentes em segurança

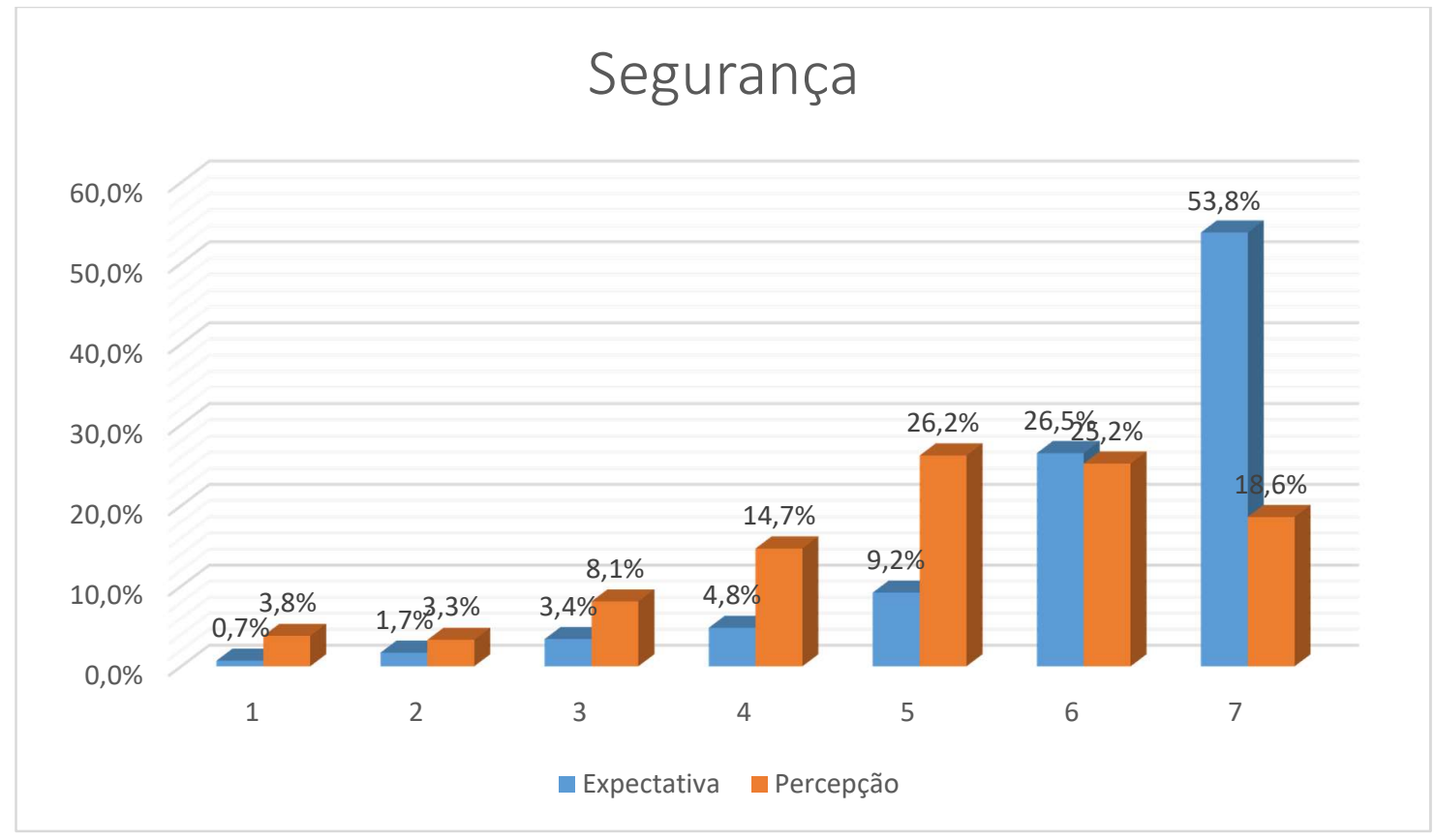

Fonte: Dados primários da pesquisa

Por fim, a dimensão empatia que trata: do atendimento personalizado ao usuário por parte dos servidores; do atendimento ao usuário de forma atenciosa pelos servidores; da demonstração de interesse em solucionar os problemas do usuário, não apresentou diferença significativa em relação aos percentuais de votos nas outras dimensões.

Vale, porém, destacar a afirmativa que representa $\mathrm{o}$ atendimento personalizado do usuário foi avaliado, de acordo com expectativa, com o valor 6 com $30,6 \%$ dos votos da escala que vai até 7 . Já a percepção do usuário a respeito da mesma afirmativa ficou em 4 com $22,9 \%$ dos votos, demonstrando alguma indiferença em relação a importância para o desenvolvimento das atividades.

Fazendo a mesma analogia comentada no gráfico anterior, podemos dizer que o usuário que não recebe o atendimento personalizado em razão da complexidade do serviço contratado vai pensar duas vezes antes fazer uma nova contratação. É claro que se deve levar em consideração a questão do monopólio estatal em 
determinados tipos de serviços. Com isso, não há por parte dos gestores preocupações em fazer um atendimento personalizado ao usuário tendo em vista as suas condições de atuação no mercado.

Gráfico 13-Percentual médio dos respondentes em empatia

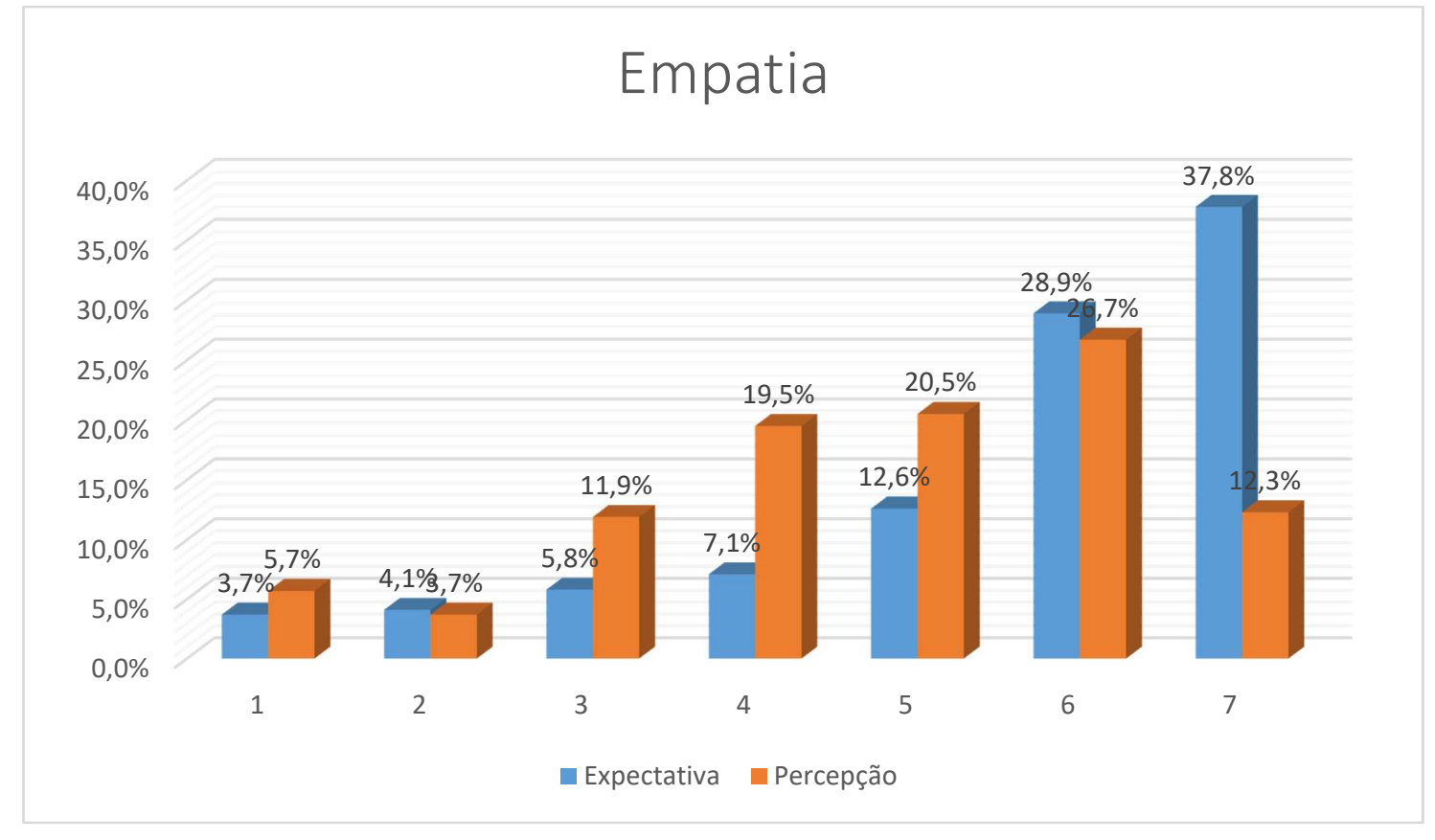

Fonte: Dados primários da pesquisa

\subsection{APLICAÇÃO DO ALPHA DE CRONBACH}

De acordo com o proposto no quadro 8 os coeficientes $(\alpha)$ relativos a expectativa e desempenho para as seis dimensões propostas - calculados conforme apresentado no quadro 9 com utilização da ferramenta EXCEL - variaram de 1,163 a 1,494, mostrando a necessidade uma reflexão maior sobre a amostra.

O exemplo estudado em (SCRAMIM; RIEG; MAIA, 2015) diz que quando o $(\alpha)$, tanto da expectativa, quanto da percepção variar entre 0,4 e 0,75 sugere-se eliminação de item com pouca relação com as dimensões estudadas. No caso em que estamos estudando a situação pareceu interessante levando em conta o perfil amostral.

Toda a amostra avaliada conhece bem o IPEA, pois boa parte dos respondentes são servidores. Os demais são colaboradores terceirizados e bolsistas. 
Não dá, por exemplo, para alegar falta de conhecimento da estrutura da instituição e seus modos operandi.

Observando os números no quadro 9 podemos afirmar que o coeficiente $(\alpha)$ encontrado por dimensão estaria um pouco acima do esperado. $\mathrm{Na}$ literatura estudada não foi encontrado exemplos de resultados semelhantes ao encontrado nesta pesquisa. Porém, quando se trata da análise sobre as 22 afirmativas os resultados estão absolutamente dentro do previsto no quadro 8. Ou seja, esse quadro mostra que os valores referentes aos índices de confiança maior que 0,9 são considerados muito alto.

Quadro 9-Valores do Alpha de Conbach ( $\alpha$ )

\begin{tabular}{|c|c|c|c|c|c|}
\hline \multirow{2}{*}{ 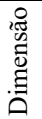 } & \multirow{2}{*}{$\underset{\Xi}{\Xi}$} & \multicolumn{2}{|c|}{ Percepção (P) } & \multicolumn{2}{|c|}{ Expectativa (E) } \\
\hline & & Var & Soma & Var & Soma \\
\hline \multirow{6}{*}{ 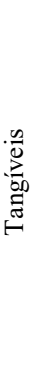 } & E1 & 3,340 & 237 & 1,498 & 596 \\
\hline & E2 & 2,381 & 300 & 1,137 & 632 \\
\hline & E3 & 2,217 & 351 & 0,511 & 654 \\
\hline & E4 & 2,395 & 311 & 2,113 & 491 \\
\hline & Soma & 10,333 & 2.230 & 5,259 & 5.218 \\
\hline & \multicolumn{2}{|c|}{ Confiança } & 1,327 & & 1,332 \\
\hline \multirow{8}{*}{ 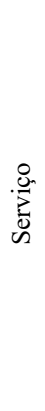 } & E5 & 3,313 & 293 & 3,263 & 502 \\
\hline & E6 & 2,364 & 310 & 1,031 & 602 \\
\hline & E7 & 2,365 & 294 & 0,927 & 608 \\
\hline & E8 & 2,411 & 306 & 0,664 & 634 \\
\hline & E9 & 2,666 & 348 & 0,788 & 635 \\
\hline & E10 & 2,626 & 336 & 1,183 & 624 \\
\hline & Soma & 15,745 & 512 & 7,856 & 2.525 \\
\hline & \multicolumn{2}{|c|}{ Confiança } & 1,163 & & 1,196 \\
\hline \multirow{5}{*}{ 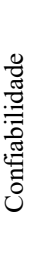 } & E11 & 2,100 & 333 & 1,505 & 588 \\
\hline & E12 & 2,475 & 322 & 1,079 & 603 \\
\hline & E13 & 3,101 & 292 & 1,130 & 611 \\
\hline & Soma & 7,676 & 450 & 3,714 & 136 \\
\hline & \multicolumn{2}{|c|}{ Confiança } & 1,474 & & 1,459 \\
\hline \multirow{4}{*}{ 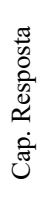 } & E14 & 2,472 & 293 & 1,350 & 578 \\
\hline & E15 & 2,456 & 303 & 1,695 & 541 \\
\hline & E16 & 3,014 & 278 & 2,687 & 515 \\
\hline & Soma & 7,942 & 158 & 5,732 & 1.002 \\
\hline
\end{tabular}




\begin{tabular}{|c|c|c|c|c|c|}
\hline & \multicolumn{2}{|c|}{ Confiança } & 1,425 & & 1,326 \\
\hline \multirow{5}{*}{ 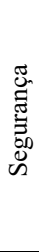 } & E17 & 2,362 & 391 & 0,828 & 633 \\
\hline & E18 & 2,166 & 313 & 2,333 & 543 \\
\hline & E19 & 2,056 & 359 & 0,970 & 631 \\
\hline & Soma & 6,584 & 1.537 & 4,131 & 2.641 \\
\hline & \multicolumn{2}{|c|}{ Confiança } & 1,494 & & 1,331 \\
\hline \multirow{5}{*}{ 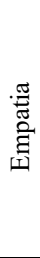 } & E20 & 2,817 & 296 & 3,788 & 451 \\
\hline & E21 & 2,230 & 359 & 1,606 & 599 \\
\hline & E22 & 2,381 & 343 & 1,400 & 592 \\
\hline & Soma & 7,428 & 1.072 & 6,794 & 6.972 \\
\hline & \multicolumn{2}{|c|}{ Confiança } & 1,490 & & 1,332 \\
\hline \multirow{2}{*}{$\begin{array}{l}\bar{\pi} \\
\text { एँّ }\end{array}$} & Soma & 55,708 & 1.134 & 60,178 & 2.968 \\
\hline & \multicolumn{2}{|c|}{ Confiança } & 0,996 & & 1,026 \\
\hline
\end{tabular}

Fonte: Dados primários da pesquisa

\subsection{ANALISE ESTATÍSTICA DAS EXPECTATIVAS E PERCEPÇÕES}

A análise dos dados desta pesquisa parte do princípio da necessidade de se fazer um paralelo entre a expectativa que o usuário teria em relação às condições de infraestrutura adequadas ao fornecimento de um determinado tipo de serviço e a real situação em que se é fornecido esse mesmo tipo de serviço. Quando se pensa em satisfação de uma necessidade o usuário forma uma opinião (percepção) que pode ou não ser favorável. Nesse sentido, Slack et al (1997) aponta que as relações entre expectativa e percepções dos usuários pode ser entendida dentro das seis dimensões estudadas como:

a) Expectativas < percepções: a qualidade percebida é boa;

b) Expectativas $=$ percepções: a qualidade percebida é aceitável;

c) Expectativas > percepções: a qualidade percebida é pobre.

Neste paralelo proposto para avaliação da qualidade dos serviços ficou demonstrado alguns problemas estruturais da instituição que passaremos a comentar conforme destacados nos quadros 10, 11, 12, 13, 14 e 15 .

\subsubsection{Discussão dos resultados}

Na dimensão Aspectos Tangíveis, quadro 10, os usuários demonstram expectativa com valores médios entre 5 e 7 . Para a percepção os valores ficaram entre 3,3 e 5 . Isso quer dizer que, quando se trata de infraestrutura de 
trabalho o GAP chega a quase 3 pontos negativos. Neste caso a situação organizacional do ambiente de trabalho não está adequada em função das especificidades das atividades desenvolvidas. Quanto à relevância dos mesmos itens, o quadro mostra uma média maior na percepção do que na expectativa. Numa visão mais geral, isso pode significar o grau de relevância maior de determinadas afirmativas em relação a outras. Para o Gestor essa situação demonstra a necessidade de priorização de investimentos e/ou atuação mais forte nas áreas em que possa contribuir mais para a melhoria da qualidade dos serviços prestados. Citamos como exemplo a afirmativa que trata das instalações físicas onde teve a média mais baixa, 3,39, para percepção, enquanto que a expectativa em relação ao mesmo item foi 6,08 .

Dentro do proposito de identificação dos fatores de gestão que contribuem para a falta de qualidade na prestação de serviços do IPEA à sociedade, o resultado dos dados mostrados nesta dimensão representa uma parte importante dos problemas de gestão que interferem na percepção dos usuários.

Há, portanto, uma necessidade de se pensar uma nova sede para o IPEA com concepção diferente da atual em que possa dar ao pesquisador um ambiente moderno. Esse conceito de ambiente moderno para o tipo de trabalho desenvolvido pelo IPEA deve atender ao princípio da integração maior entre os diversos segmentos de estudos em instalações preparadas para tal. Pensa-se, por exemplo, em edificações com poucos andares e vários blocos e com área de circulação que traga obrigatoriamente os usuários para um mesmo ambiente de convivência em momentos de relaxamento, descanso ou pausa para um café.

Além do mais, o Plano Estratégico 2013 - 2023 identifica uma carência de instituições, métodos e técnicas voltados para a avaliação de políticas públicas. Isso quer dizer que o Brasil tem deficiência na avaliação de políticas públicas em razão da falta de foco. Aí entra a questão da Governança corporativa com o papel do acompanhamento da gestão, trabalhando para dar mais clareza ao plano de gestão e suas correções de rumo. 
Na visão do Plano Estratégico do IPEA 2013-2023 as deficiências de avaliação de pesquisa de políticas públicas estão na falta de outras instituições públicas, métodos e técnicas capazes de atuar em parcerias capazes de ter efeito multiplicador para as outras administrações estaduais e municipais. Tudo isso nos leva a pensar no grau de importância da dimensão aspectos tangíveis para as atividades de pesquisa do IPEA. O resultado da pesquisa mostra essa dimensão como a que tem maior divergência entre as dimensões pesquisadas.

Do ponto de vista da governança corporativa, a instituição deve dispor de ambiente adequado ao desenvolvimento das atividades e tudo que há de mais moderno em tecnologia da informação, mão de obra capacitada e as parcerias com outras instituições públicas de pesquisas. Tais condições podem contribuir com um resultado mais eficiente em termo de quantidade e quantidade dos estudos e pesquisas dentro do IPEA.

Quadro 10-Aspectos tangíveis

\begin{tabular}{|c|c|c|c|c|c|c|c|c|c|c|}
\hline \multirow{2}{*}{ Е } & \multicolumn{2}{|c|}{ Percepção (P) } & \multicolumn{2}{|c|}{ Expectativa (E) } & GAP & \multicolumn{2}{|c|}{ Relevância (RP) } & \multicolumn{2}{|c|}{$\begin{array}{c}\text { Relevância } \\
\text { (RE) }\end{array}$} & GAP \\
\cline { 2 - 12 } & Média & $\begin{array}{c}\text { Desv. } \\
\text { Padrão }\end{array}$ & Média & $\begin{array}{c}\text { Desv. } \\
\text { Padrão }\end{array}$ & P-E & Média & $\begin{array}{c}\text { Desv. } \\
\text { Padrão }\end{array}$ & Média & $\begin{array}{c}\text { Desv. } \\
\text { Padrão }\end{array}$ & RP-RE \\
\hline E1 & 3,39 & 1,828 & 6,08 & 1,224 & $-2,69$ & 5,14 & 1,995 & 5,70 & 1,212 & $-0,56$ \\
\hline E2 & 4,29 & 1,543 & 6,45 & 1,066 & $-2,16$ & 5,80 & 1,691 & 6,27 & 1,231 & $-0,47$ \\
\hline E3 & 5,01 & 1,489 & 6,67 & 0,715 & $-1,66$ & 6,01 & 1,450 & 6,62 & 0,936 & $-0,61$ \\
\hline E4 & 4,44 & 1,548 & 5,01 & 1,454 & $-0,57$ & 4,33 & 1,657 & 4,55 & 1,587 & $-0,22$ \\
\hline Média & 4,28 & 1,60 & 6,05 & 1,11 & $-1,77$ & 5,32 & 1,70 & 5,79 & 1,24 & $-0,47$ \\
\hline
\end{tabular}

A Dimensão Serviço foi pensada com vistas a sistematizar as informações relativas à qualidade dos serviços técnicos fornecidos pelo IPEA sem descaracterizar a dimensão original escolhida. $\mathrm{Na}$ sistematização percebem-se alguns GAPs com valores negativos considerados importantes para a melhoria da qualidade da prestação de serviços. Entre elas, estão as afirmativas E7, E8 e E9, constante do quadro 11, que tratam de questões fundamentais para a missão institucional do IPEA, como instituição pública de pesquisa de excelência. $\mathrm{O}$ que se estrai disso tem a ver com a falta de confiança do usuário no trabalho fornecido por razões diversas que poderíamos dar como 
exemplo: a baixa capacidade de influenciação, aproveitamento e reconhecimento por parte do demandante; baixa articulação com o Governo Federal; desarticulação e falta de foco na agenda de pesquisa, entre outros fatos constatados na pesquisa qualitativa com os atores internos e externos constante do Plano Estratégico do IPEA 2013 - 2023.

O resultado desta dimensão, queira ou não, tem influência das outras dimensões. Primeiro porque a mão de obra qualificada, as instalações adequadas, a tecnologia de informações e as parcerias corretas dão todo o suporte ao desenvolvimento do trabalho de pesquisa.

Dentro do contexto mostrado na pesquisa infere-se que a baixa qualidade na prestação de serviços pelo IPEA tem origem na falta de organização das estruturas física e tecnológica, falta de foco, na pouca mão de obra qualificada, na falta de parcerias com outras instituições públicas de pesquisa. Além do mais, falta incorporar os princípios organizacionais das boas práticas de governança, tendo como objetivos principais garantir a entrega de benefícios econômicos, sociais e ambientais para os cidadãos; garantir que a organização seja, e pareça, responsável para com os cidadãos; entre outros.

Quadro 11-serviços

\begin{tabular}{|c|c|c|c|c|c|c|c|c|c|c|}
\hline \multirow{2}{*}{ 巳్ } & \multicolumn{2}{|c|}{ Percepção (P) } & \multicolumn{2}{|c|}{ Expectativa (E) } & GAP & \multicolumn{2}{|c|}{ Relevância (RP) } & \multicolumn{2}{|c|}{$\begin{array}{c}\text { Relevância } \\
(\mathrm{RE})\end{array}$} & GAP \\
\cline { 2 - 12 } & Média & $\begin{array}{c}\text { Desv. } \\
\text { Padrão }\end{array}$ & Média & $\begin{array}{c}\text { Desv. } \\
\text { Padrão }\end{array}$ & P-E & Média & $\begin{array}{c}\text { Desv. } \\
\text { Padrão }\end{array}$ & Média & $\begin{array}{c}\text { Desv. } \\
\text { Padrão }\end{array}$ & RP-RE \\
\hline E5 & 4,19 & 1,820 & 5,12 & 1,806 & $-0,93$ & 5,46 & 1,548 & 5,38 & 1,543 & 0,08 \\
\hline E6 & 4,43 & 1,538 & 6,14 & 1,015 & $-1,71$ & 5,61 & 1,458 & 6,04 & 1,148 & $-0,43$ \\
\hline E7 & 4,20 & 1,538 & 6,20 & 0,963 & $-2,00$ & 5,91 & 1,462 & 6,12 & 0,987 & $-0,21$ \\
\hline E8 & 4,37 & 1,553 & 6,47 & 0,815 & $-2,10$ & 5,97 & 1,541 & 6,27 & 1,041 & $-0,30$ \\
\hline E9 & 4,97 & 1,633 & 6,48 & 0,888 & $-1,51$ & 6,21 & 1,261 & 6,41 & 0,940 & $-0,20$ \\
\hline E10 & 4,80 & 1,621 & 6,37 & 1,088 & $-1,57$ & 6,09 & 1,359 & 6,38 & 0,891 & $-0,29$ \\
\hline Média & 4,49 & 1,62 & 6,13 & 1,10 & $-1,64$ & 5,88 & 1,44 & 6,10 & 1,09 & $-0,23$ \\
\hline
\end{tabular}

$\mathrm{Na}$ dimensão confiabilidade observa-se que o valor médio dos GAPs também está em um patamar baixo. Nesse caso o que chama mais atenção é o item E13 que trata da informação do prazo para realização do serviço. Quando o usuário não recebe essa informação durante a contratação é claro que ela 
desconfia e pode não voltar a contratar. O Plano Estratégico do IPEA não tratou diretamente do tema, no entanto, várias questões estudadas nele remetem a esta dimensão. O cumprimento de prazo fica comprometido em razão da desarticulação entre as diretorias e a falta de foco da agenda de pesquisa; das "amarras" ligadas à gestão de recursos humanos e a pouca clareza interna e externa de sua missão institucional.

Se comparados com as dimensões estudas pelo Plano Estratégico do IPEA, fica claro a necessidade de correção das falhas mostradas nesse mesmo plano principalmente do ponto de vista externo. Entre os problemas apontados, estão a falta de clareza de até onde pode ir a liberdade de expressão e desarticulação das ações de comunicação externa; os graves problemas no site. "Parece uma agência de notícias". Do ponto de vista do plano é necessário focar na disponibilização de publicações e dados, não de notícias aleatórias.

Em função dos problemas apontados pela pesquisa podemos restabelecer toda a teoria de governança corporativa com vista a organização de uma equipe que trate de todos esses problemas dentro de uma visão holística de modo a minimizar os atuais problemas de gestão que mais emperram os trabalhos dos pesquisadores e gestores.

Quadro 12-confiabilidade

\begin{tabular}{|c|c|c|c|c|c|c|c|c|c|c|}
\hline \multirow{2}{*}{ Е } & \multicolumn{2}{|c|}{ Percepção (P) } & \multicolumn{2}{|c|}{ Expectativa (E) } & GAP & \multicolumn{2}{|c|}{ Relevância (RP) } & \multicolumn{2}{|c|}{$\begin{array}{c}\text { Revância } \\
(\mathrm{RE})\end{array}$} & GAP \\
\cline { 2 - 12 } & Média & $\begin{array}{c}\text { Desv. } \\
\text { Padrão }\end{array}$ & Média & $\begin{array}{c}\text { Desv. } \\
\text { Padrão }\end{array}$ & P-E & Média & $\begin{array}{c}\text { Desv. } \\
\text { Padrão }\end{array}$ & Média & $\begin{array}{c}\text { Desv. } \\
\text { Padrão }\end{array}$ & RP-RE \\
\hline E11 & 4,76 & 1,449 & 6,00 & 1,227 & $-1,24$ & 5,54 & 1,557 & 5,89 & 1,338 & $-0,35$ \\
\hline E12 & 4,60 & 1,573 & 6,15 & 1,039 & $-1,55$ & 5,71 & 1,446 & 6,02 & 1,193 & $-0,31$ \\
\hline E13 & 4,17 & 1,761 & 6,23 & 1,063 & $-2,06$ & 5,34 & 1,641 & 5,98 & 1,235 & $-0,64$ \\
\hline Média & 4,51 & 1,59 & 6,13 & 1,11 & $-1,62$ & 5,53 & 1,55 & 5,96 & 1,26 & $-0,43$ \\
\hline
\end{tabular}

A capacidade de resposta segue a mesma linha de pensamento do item c. Sua organização interna deve dispor de estrutura que possua múltiplos canais de contato com os usuários (Serviço de Atendimento ao usuário, site, email), e que estes canais permitam não só que o usuário entre em contato com a 
instituição sempre que conveniente, mas principalmente que a instituição seja capaz de responder a estas requisições rapidamente, e também com um serviço de qualidade, que, novamente, venha a atender às expectativas dos usuários. Os GAPs negativos encontrados nesta dimensão sugerem a necessidade de revisão da estrutura como um todo.

Assim como em todas as outras dimensões, a capacidade de resposta do IPEA, considerando a percepção menos a expectativa dos usuários é considerada baixa. A literatura estudada mostra que valores negativos dos GAPS bem próximos de zero estaria dentro de uma normalidade aceitável. O fato é que no setor público mensurar essa e outras questões relacionadas ao tema requer um rompimento de barreiras quase intransponíveis nos dias atuais.

Outro fator a ser considerado na pesquisa tem a ver com o grau de relevância dos itens que compõem a dimensão estudada. As vezes o usuário avalia bem o item, no entanto considera pouco relevante para o desenvolvimento das atividades. Isso dá ao leitor a noção de que a instituição pode atribuir prioridades nos investimentos para melhoria das atividades. Por outro lado, outros itens podem ser mal avaliados e ser considerado relevante para o desenvolvimento das atividades, o que corrobora o raciocínio anterior quando se fala em prioridade de investimento.

Quadro 13-capacidade de resposta

\begin{tabular}{|c|c|c|c|c|c|c|c|c|c|c|}
\hline \multirow{2}{*}{$\underset{\Xi}{\text { 巳ี }}$} & \multicolumn{2}{|c|}{ Percepção (P) } & \multicolumn{2}{|c|}{ Expectativa (E) } & GAP & \multicolumn{2}{|c|}{ Relevância (RP) } & \multicolumn{2}{|c|}{$\begin{array}{c}\text { Relevância } \\
(\mathrm{RE})\end{array}$} & GAP \\
\cline { 2 - 11 } & Média & $\begin{array}{c}\text { Desv. } \\
\text { Padrão }\end{array}$ & Média & $\begin{array}{c}\text { Desv. } \\
\text { Padrão }\end{array}$ & P-E & Média & $\begin{array}{c}\text { Desv. } \\
\text { Padrão }\end{array}$ & Média & $\begin{array}{c}\text { Desv. } \\
\text { Padrão }\end{array}$ & RP-RE \\
\hline E14 & 4,19 & 1,572 & 5,90 & 1,162 & $-1,71$ & 5,31 & 1,547 & 5,73 & 1,127 & $-0,42$ \\
\hline E15 & 4,33 & 1,567 & 5,52 & 1,302 & $-1,19$ & 5,37 & 1,436 & 5,45 & 1,277 & $-0,08$ \\
\hline E16 & 3,97 & 1,736 & 5,26 & 1,639 & $-1,29$ & 4,66 & 1,856 & 5,07 & 1,607 & $-0,41$ \\
\hline Média & 4,16 & 1,63 & 5,56 & 1,37 & $-1,40$ & 5,11 & 1,61 & 5,42 & 1,34 & $-0,30$ \\
\hline
\end{tabular}

Fonte: Dados primários da pesquisa

No caso do IPEA essa dimensão segurança trata do conhecimento amplo dos servidores nas áreas que atuam. Quem contrata quer saber de todos os detalhes que envolvem o serviço. Deste ponto de vista, a instituição tem o dever de manter em sua estrutura interna capital intelectual capaz de dar a 
segurança necessária ao usuário de que aquele serviço é o mais adequado ao seu desejo de consumo e de que ele se perca com o tempo. Entra aí a visão do usuário da há necessidade melhoria, uma vez que, todos os GAPs encontrados foram negativos, mostrados no quadro 14 . Observando os valores médios dos GAPs anteriores, concluímos a dimensão segurança foi a que recebeu a maior média se comparados com as outras dimensões. Isso quer dizer que essa dimensão perderia ponto no rol de prioridades de investimento.

No contexto da escala SERVQUAL Para o usuário, o que gera segurança são funcionários parecerem e serem confiáveis; o sentimento de se sentir seguro em negociar com os funcionários da empresa; funcionários são educados; suporte adequado da empresa para cumprir suas tarefas corretamente. Dentro do setor público esse sentimento fica comprometido em função atos praticados pelos servidores demonstrarem insensibilidade com as necessidades do usuário, uma vez que, a instituição não depende financeiramente dele e não é cobrado como deveria pela sociedade a prestar um serviço de qualidade. Ou, o que é pior, os gestores não se sentem na obrigação prestar um bom serviço a quem os paga.

Talvez o que pode e deve ser feito é se utilizar dos conceitos de governança corporativa aplicado ao setor público e construir métodos e técnicas de avaliação dos problemas de gestão onde se busca reduzir os entraves burocráticos ligados ao medo das mudanças que tenha proposito de modernizar as relações governo/instituições/gestores/sociedade.

Quadro 14-segurança

\begin{tabular}{|c|c|c|c|c|c|c|c|c|c|c|}
\hline \multirow{2}{*}{ Е } & \multicolumn{2}{|c|}{ Percepção (P) } & \multicolumn{2}{|c|}{ Expectativa (E) } & GAP & \multicolumn{2}{|c|}{ Relevância (RP) } & \multicolumn{2}{|c|}{$\begin{array}{c}\text { Relevância } \\
(\mathrm{RE})\end{array}$} & GAP \\
\cline { 2 - 12 } & Média & $\begin{array}{c}\text { Desv. } \\
\text { Padrão }\end{array}$ & Média & $\begin{array}{c}\text { Desv. } \\
\text { Padrão }\end{array}$ & P-E & Média & $\begin{array}{c}\text { Desv. } \\
\text { Padrão }\end{array}$ & Média & $\begin{array}{c}\text { Desv. } \\
\text { Padrão }\end{array}$ & RP-RE \\
\hline E17 & 5,59 & 1,537 & 6,46 & 0,910 & $-0,87$ & 6,23 & 1,466 & 6,38 & 1,031 & $-0,15$ \\
\hline E18 & 4,47 & 1,472 & 5,54 & 1,528 & $-1,07$ & 5,29 & 1,721 & 5,49 & 1,501 & $-0,2$ \\
\hline E19 & 5,13 & 1,434 & 6,44 & 0,985 & $-1,31$ & 6,06 & 1,473 & 6,33 & 1,217 & $-0,27$ \\
\hline Média & 5,06 & 1,48 & 6,15 & 1,14 & $-1,08$ & 5,86 & 1,55 & 6,07 & 1,25 & $-0,21$ \\
\hline
\end{tabular}

Fonte: Dados primários da pesquisa 
E, por fim, a dimensão empatia foi considerada pela maioria dos respondentes indiferente para o desenvolvimento das atividades de pesquisa e gestão no IPEA. O item E20 com média de percepção de 4,23 contra a média de expectativa de 4,60 apresenta um GAP negativo de 0,37, o mesmo corresponde ao menor GAP da pesquisa.

Significa dizer que para o respondente esse item é indiferente na atuação da instituição visto que os valores são um pouco superiores ao item da escala considera indiferente. Por outro lado, não podemos deixar de fazer a mesma analogia dos GAPs que são considerados importantes para as atividades desenvolvidas até aqui. Dentre todos os GAPS negativos, citamos como exemplo o item E1 com valor de -2,69. Isso significa dizer que o IPEA deve adotar como prioridade a solução dos problemas das instalações físicas, pois o item foi o pior avaliado enquanto que a expectativa foi avaliada em 6,64 e com grau de relevância semelhante.

Não só os aspectos tangíveis devem sofrer modificações. Para dar qualidade aos serviços é necessário corrigir problemas de falta de mão de obra, humanizar o atendimento, cumprir prazos, dar a atenção que o usuário espera ter de uma instituição pública de excelência. $\mathrm{O}$ mínimo que usuário espera em razão da complexidade da demanda é que: os funcionários deem atenção individual; os funcionários saibam das suas necessidades; percepção de que os objetivos da empresa são seus objetivos; horário de trabalho conveniente com as necessidades dos usuários.

Quadro 15-empatia

\begin{tabular}{|c|c|c|c|c|c|c|c|c|c|c|}
\hline \multirow{2}{*}{ Е } & \multicolumn{2}{|c|}{ Percepção (P) } & \multicolumn{2}{|c|}{ Expectativa (E) } & GAP & \multicolumn{2}{|c|}{ Relevância (RP) } & \multicolumn{2}{|c|}{$\begin{array}{c}\text { Relevância } \\
(\mathrm{RE})\end{array}$} & GAP \\
\cline { 2 - 12 } & Média & $\begin{array}{c}\text { Desv. } \\
\text { Padrão }\end{array}$ & Média & $\begin{array}{c}\text { Desv. } \\
\text { Padrão }\end{array}$ & P-E & Média & $\begin{array}{c}\text { Desv. } \\
\text { Padrão }\end{array}$ & Média & $\begin{array}{c}\text { Desv. } \\
\text { Padrão }\end{array}$ & RP-RE \\
\hline E20 & 4,23 & 1,678 & 4,60 & 1,946 & $-0,37$ & 4,67 & 1,800 & 4,70 & 1,817 & $-0,03$ \\
\hline E21 & 5,13 & 1,493 & 6,11 & 1,267 & $-0,98$ & 5,76 & 1,459 & 5,86 & 1,407 & $-0,1$ \\
\hline E22 & 4,90 & 1,543 & 6,04 & 1,183 & $-1,14$ & 5,49 & 1,491 & 5,74 & 1,445 & $-0,25$ \\
\hline Média & 4,75 & 1,57 & 5,58 & 1,47 & $-0,83$ & 5,31 & 1,58 & 5,43 & 1,56 & $-0,13$ \\
\hline
\end{tabular}

Fonte: Dados primários da pesquisa 
De modo geral a pesquisa apontou para problemas que são crônicos no serviço público. Entre os principais estão a gestão ineficiente das estruturas físicas que abrigam as instituições; a execução orçamentaria deficiente - sem priorização de ações relevantes - em todos os níveis hierárquicos; a definição de metas de qualidade na prestação de serviços; a falta de investimento recursos tecnológicos e humanos e uma definição mais clara e objetiva da área de atuação.

\subsection{CONSIDERAÇÕES FINAIS}

Esta pesquisa teve como objetivo avaliar a qualidade dos serviços prestado IPEA sob a ótica da governança corporativa, tendo como base a implantação do Plano Estratégico 2013 - 2023. Foram considerados pontos fundamentais para avaliação da qualidade dos serviços dimensões ligadas aos aspectos tangíveis; serviços; confiabilidade; capacidade de resposta; segurança; empatia. Temas esses que fazem parte do citado Plano Estratégico.

De modo a subsidiar uma análise dentro de um contexto mais amplo da Instituição, buscamos compreender o andamento das atividades por meio da verificação da evolução da produção de conhecimento, da verificação da execução orçamentária e da composição da força de trabalhado.

Depois de identificadas as condições atuais em que a Instituição se encontra no cenário atual, passamos a analisar o Plano Estratégico levando em conta as funções da governança corporativa. O propósito, nesse caso, foi delimitar os pontos estudados que mais interferem na qualidade da prestação de serviço, tanto no setor privado, quanto no setor público, guardadas as devidas diferenças de propósitos.

Dentro das funções de governança onde se busca supervisionar a gestão; envolver as partes interessadas; gerenciar riscos estratégicos; gerenciar conflitos internos; auditar e avaliar o sistema de gestão e controle; e promover a accountability, estudadas pelo (TCU, 2011) foi possível comparar os pontos estudados no Plano Estratégico com a escala de avaliação da qualidade dos serviços pelo IPEA por meio da Escala SERVQUAL. 
O Plano Estratégico do IPEA teve como propósito de melhoria do ponto de vista finalístico (i) a avaliação e proposta de políticas públicas essenciais para o desenvolvimento do país; (ii) a formulação de estudos prospectivos para orientar estratégias de desenvolvimento de médio e longo prazo; (iii) o assessoramento do Estado na melhoria da qualidade de suas decisões; (iv) a contribuição para a qualificação do debate público quanto aos rumos do desenvolvimento do pais e da ação do Estado. O mesmo Plano Estratégico definiu como proposito de melhora do ponto de vista da gestão (i) assegurar produtividade com qualidade e quantitativo adequado de servidores; (ii) garantir confiabilidade, agilidade e efetividade aos processos e sistemas de gestão; (iii) fortalecer e articular a comunicação interna e externa; e (iv) garantir foco e sinergia ao plano de trabalho.

Levando em conta estas questões, os resultados apresentados na pesquisa permitem concluir que o IPEA está buscando dar mais agilidade aos processos internos de melhoria na qualidade da prestação de serviço a sociedade. No entanto, o próprio Plano Estratégico 2013 - 2023 relata as dificuldades (gargalos) encontradas no setor público que inibem essa melhoria. O primeiro e mais importante deles diz respeito a falta de investimento em recursos humanos, tecnológicos e materiais; em pesquisas realmente importantes para o País.

Em segundo lugar, o excesso de burocracia e normas que dificultam a articulação com o Governo Federal, outros órgãos públicos estaduais e municipais, instituições de pesquisas e a iniciativa privada.

\subsubsection{Limitações Encontradas}

Na definição da amostra o objetivo era aplicar o questionário a servidores e colaboradores de outras instituições do serviço público limitado ao tamanho da amostra. Entretanto, os questionários eletrônicos encaminhados não retornaram dentro prazo estabelecido. Por isso não tivemos como sistematizar a expectativa e percepção do ponto de vista de outras instituições públicas e outras entidades privadas de pesquisa. 
A amostra obtida é formada majoritariamente por servidores, colaboradores e bolsistas do IPEA. Do ponto de vista do conhecimento dos problemas internos, essa amostra parece interessante mesmo não tendo atingido $100 \%$ previsto.

Outra limitação importante está relacionada a falta de estudo com o mesmo objetivo no setor público;

\subsubsection{Recomendações}

Aperfeiçoamento dos questionários aos propósitos específicos e aplicação do mesmo instrumento de pesquisa em outras instituições públicas com objetivo de se obter resultados mais conclusivos.

Seria interessante observar, por exemplo, se existem diferenças estatisticamente significantes em grupos de servidores de outras instituições com aplicação dos mesmos questionários. Nesse caso poderíamos identificar o grau de importância das dimensões para os diferentes grupos. Do ponto de vista da governança isso seria fundamental para embasar as decisões de investimento em busca da qualidade da prestação de serviço. 


\section{REFERÊNCIAS}

ALMEIDA, M. A. et al. Evolução da Qualidade das Práticas de Governança Corporativa: um Estudo das Empresas Brasileiras de Capital Aberto Não Listadas em Bolsa. Revista de Administração Contemporânea (RAC), 2010.

ARRUDA, G. S. DE; MADRUGA, S. R.; JUNIOR, N. I. D. F. A Governança Corporativa e a Teoria da Agência em Consonância com a Controladoria. Revista de Administração da UFSM, v. 1, n. 1, p. 71-84, 2008.

AUGUSTO, P.; MIGUEL, C.; SALOMI, G. E. Uma revisão dos modelos para medição da qualidade em serviços. Produçao, v. 14, p. 12-30, 2004.

BENEDICTO, S. C. DE; RODRIGUES, Â. C.; ABBUD, E. L. Governança corporativa: uma análise da sua aplicabilidade no setor público. Xxviii Encontro Nacional De Engenharia De Produção, 2008.

BRANCO, C. S. C.; CRUZ, C. S. DA. A prática de governança corporativa no setor público federal. 2013.

CATAPAN, A.; CHEROBIM, A. P. M. S. Estado da arte da governança corporativa: estudo bibliométrico nos anos de 2000 a 2010. RACE, Unoesc, 2010.

CORREIA, L. F.; AMARAL, H. F. Reflexão sobre as funções da governança corporativa. Revista de Gestão USP, v. 13, n. 1, p. 43-55, 2006.

GAIO, R. M. et al. Expectativa e percepção de qualidade dos egressos (2010-2012 do curso de serviço social da UFSC. v. d, p. 1-17, 2012.

IPEA. Diagnóstico interno_resultado da pesquisa com quadro de colaboradores internos.

Instituto de Pesquisa Econômica Aplicada, 2013a.

IPEA. Plano estratégico do IPEA 2013-2023. Instituto de Pesquisa Econômica Aplicada, $2013 b$. 
IPEA. Plano Estratégico do Ipea 2023. Instituto de Pesquisa Econômica Aplicada, 2013c.

IPEA. Pesquisa qualitativa com atores externos e internos ao IPEA - relatório síntese. Instituto de Pesquisa Econômica Aplicada, 2013d.

IPEA. Pesquisa qualitativa com atores internos - visão geral do IPEA hoje e propostas para ação estratégica. Instituto de Pesquisa Econômica Aplicada, 2013e.

MACHADO, C. M. A importância dos preceitos de governança corporativa e de controle interno sobre a evolução e a internacionalização das normas de contabilidade e auditoria. [s.1.] Conselho Regional de Contabilidade do Rio Grande do Sul Rua, 2011. MARQUES, M. DA C. DA C. Aplicação dos Princípios da Governança Corporativa ao Sector Público. Revista de Administração Contemporânea, 2007.

MATIAS-PEREIRA, J. A Governança Corporativa Aplicada no Setor Público Brasileiro. 2010.

MELLO, G. R. DE. Governança Corporativa no Setor Público Federal Brasileiro. 2006. MONTEIRO, R. P.; HAMMES, P. Governança Corporativa no Setor Público: Estudo de Seus Princípios para Alcance da Eficácia na Gestão Pública. Statewide Agricultural Land Use Baseline 2015, 2015.

ROSSONI, L.; MACHADO-DA-SILVA, C. L. Institucionalismo Organizacional e Práticas de Governança Corporativa. RAC, Curitiba, 2010.

SCRAMIM, F. C. L.; RIEG, D. L.; MAIA, D. B. Adaptação do Instrumento SERVQUAL para mensuração da qualidade em serviços prestados por transportadoras rodoviárias de cargas. Sistemas \& Gestão, v. 10, p. 396-407, 2015.

SIMÃO, C. Z. S. Governança Corporativa no Senado Federal. 2014.

TCU, T. DE C. DA U.-. Referencial Básico de Governança Aplicável a Órgãos e Entidades da Administração Pública e Ações Indutoras de Melhoria. 2011. 
Sites visitados:

http://www.planejamento.gov.br/assuntos/empresas-estatais/noticias/resolucoes-

aperfeicoam-papel-do-governo-como-acionista-de-estatais - em 6 de setembro de 2016.

http://www.cgu.gov.br/noticias/2016/05/cgu-e-planejamento-instruem-orgaos-federaissobre-governanca-e-gestao-de-riscos - em 6 de setembro de 2016.

http://www.portaldatransparencia.gov.br/PortalComprasDiretasPrincipal2.asp - em 6 de setembro 2016.

http://www.geraldoloureiro.com/wiki/index.php?title=Diferen $\% \mathrm{C} 3 \% \mathrm{~A} 7 \mathrm{as}$ entre Governan $\% \mathrm{C} 3 \% \mathrm{~A} 7 \mathrm{a}$ no Setor P\%C3\%BAblico e Privado - em 6 de setembro de 2016.

https://pt.wikipedia.org/wiki/Escala_servqual - em 5 de outubro de 2016.

http://paineldoservidor.planejamento.gov.br/QvAJAXZfc/opendoc.htm?document=Boletim \%20Estatistico $\% 20 \mathrm{de} \% 20$ Pessoal.qvw\&host=Local\&anonymous=true -3 de novembro de 2016.

http://www.brasil.gov.br/governo/2009/11/governo-federal-e-formado-por-ministeriossecretarias-e-orgaos-especiais. -3 de novembro de 2016.

http://www.ipea.gov.br/portal/images/stories/140728 sintese pe.png - em 3 de novembro de 2016. 


\section{APÊNDICES}

\section{Expectativa dos usuários (interno e externo)quanto à "qualidade" dos serviços prestados pelo IPEA}

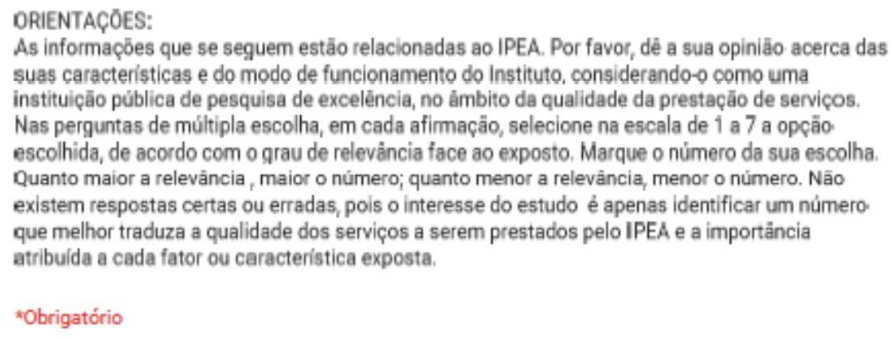

As informaçōes que se seguem estão relacionadas ao IPEA. Por favor, dê a sua opiniāo acerca das șuas çaracteristiças e do modo de funcionamento do Instituto considerando-o como uma instituiçẫo pública de pesquisa de excelência, no âmbito da qualidade da prestação de serviços. Nas perguntas de múltipla escolha, em cada afirmação, selecione na escala de 1 a 7 a opção: escolhida, de acordo com o grau de relevåncia face ao exposto. Marque o número da sua escolha. Quanto maior a relevância , maior o número; quanto menor a relevância, menor o número. Nāo existem respostas certas ou erradas, pois o interesse do estudo é apenas identificar um número. que melhor traduza a qualidade dos serviços a serem prestados pelo IPEA e a importảncia atribuida a cada fator ou caracteristica exposta.

*Obrigatório

1. Uma Instituição de pesquisa de excelência deveria dispor de instalações físicas modernas *

$\begin{array}{lccccccc} & \begin{array}{c}\text { (1) Discordo } \\ \text { Totalmente }\end{array} & \text { (2) } & \text { (3) } & \begin{array}{c}(4) \\ \text { Indifferente }\end{array} & \text { (5) } & \text { (6) } & \begin{array}{c}(7) \\ \text { Concordo } \\ \text { Totalmente }\end{array} \\ \text { Expectativa } & \bigcirc & \bigcirc & \bigcirc & \bigcirc & \bigcirc & \bigcirc & \bigcirc \\ \begin{array}{l}\text { Grau de } \\ \text { Relevância }\end{array} & \bigcirc & \bigcirc & \bigcirc & \bigcirc & \bigcirc & \bigcirc & \bigcirc\end{array}$

2. A biblioteca de uma instituição de pesquisa de excelência deveria dispor de acervo e repositórios do conhecimento modernos e atualizados *

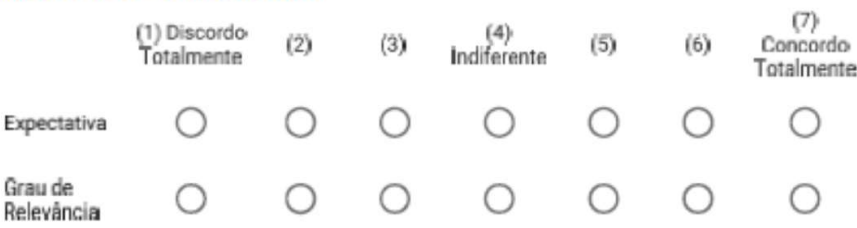

3.Uma Instituição de pesquisa de excelência deveria Dispor de equipamentos de informática modernos e base de dados atualizada *

$\begin{array}{lccccccc} & \begin{array}{c}\text { (1) Discordo } \\ \text { Totalmente }\end{array} & \text { (2) } & \text { (3) } & \begin{array}{c}(4) \\ \text { Indiferente }\end{array} & \text { (5) } & \text { (6) } & \begin{array}{c}\text { (7) } \\ \text { Concordo } \\ \text { Totalmente }\end{array} \\ \text { Expectativa } & \bigcirc & \bigcirc & \bigcirc & \bigcirc & \bigcirc & \bigcirc & \bigcirc \\ \begin{array}{l}\text { Grau de } \\ \text { Relevância }\end{array} & \bigcirc & \bigcirc & \bigcirc & \bigcirc & \bigcirc & \bigcirc & \bigcirc\end{array}$


4.Os servidores de uma instituição de pesquisa de excelência deveriam ter boa apresentação *

\begin{tabular}{|c|c|c|c|c|c|c|c|}
\hline & $\begin{array}{l}\text { (1) Discordo } \\
\text { Totalmente }\end{array}$ & (2) & (3) & $\begin{array}{l}\text { (4) } \\
\text { Indiferente }\end{array}$ & (5) & (6) & $\begin{array}{c}\text { (7) } \\
\text { Concordo } \\
\text { Totalmente }\end{array}$ \\
\hline Expectativa & $\bigcirc$ & 0 & $\bigcirc$ & $\bigcirc$ & 0 & 0 & 0 \\
\hline $\begin{array}{l}\text { Grau dee } \\
\text { Relevância }\end{array}$ & 0 & 0 & 0 & 0 & 0 & 0 & 0 \\
\hline
\end{tabular}

5.Uma instituição de pesquisa de excelência deveria ter sua área de atuação bem delimitada *

$\begin{array}{lccccccc}\text { Expectativa } & \begin{array}{c}\text { (1) Discordo } \\ \text { Totalmente }\end{array} & (2) & \text { (3) } & \begin{array}{c}\text { (4) } \\ \text { Indiferente }\end{array} & \text { (5) } & \text { (6) } & \begin{array}{c}\text { (7) } \\ \text { Concordo } \\ \text { Totalmente }\end{array} \\ \begin{array}{cccccc}\text { Grau de } \\ \text { Relevância }\end{array} & \bigcirc & \bigcirc & \bigcirc & \bigcirc & \bigcirc & \bigcirc\end{array}$

6.Uma instituição de pesquisa de excelência deveria apresentar seus trabalhos de forma a atender as necessidades dos usuários *

\begin{tabular}{|c|c|c|c|c|c|c|c|}
\hline & $\begin{array}{l}\text { (1) Discordo } \\
\text { Totalmente }\end{array}$ & (2) & (3) & $\begin{array}{l}\text { (4) } \\
\text { Indiferente }\end{array}$ & (5) & (6) & $\begin{array}{c}\text { (7) } \\
\text { Concordo } \\
\text { Totalmente }\end{array}$ \\
\hline Expectativa & 0 & 0 & $\mathrm{O}$ & 0 & 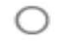 & $\bigcirc$ & $\bigcirc$ \\
\hline $\begin{array}{l}\text { irau de } \\
\text { ielevância }\end{array}$ & 0 & 0 & 0 & $\bigcirc$ & 0 & 0 & 0 \\
\hline
\end{tabular}

7.Os trabalhos desenvolvidos por uma instituição de pesquisa de excelência deveriam influenciar bastante nas tomadas de decisões *

$\begin{array}{lccccccc}\text { Expectativa } & \begin{array}{c}\text { (1) Discordo } \\ \text { Totalmente }\end{array} & \text { (2) } & \text { (3) } & \begin{array}{c}\text { (4) } \\ \text { Indifferente }\end{array} & \text { (5) } & \text { (6) } & \begin{array}{c}\text { (7) } \\ \text { concordo } \\ \text { Totalmente }\end{array} \\ \begin{array}{l}\text { Girau de } \\ \text { Releváncia }\end{array} & \bigcirc & \bigcirc & \bigcirc & \bigcirc & \bigcirc & \bigcirc \\ & \bigcirc & \bigcirc & \bigcirc & \bigcirc & \bigcirc & \bigcirc\end{array}$

8.Uma instituição pública de pesquisa de excelência deveria contribuir muito com melhoria na qualidade das decisões do Governo Central *

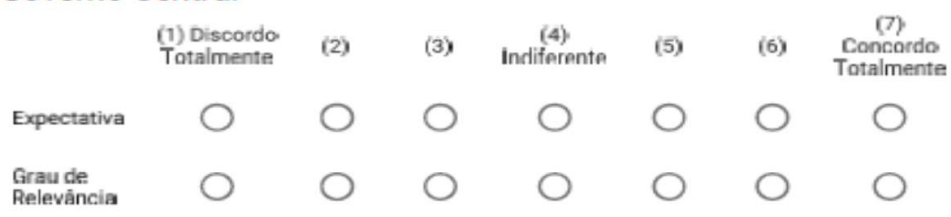

9.As pesquisas de uma instituição de pesquisa de excelência deveriam contribuir muito para a qualificação do debate público *

\begin{tabular}{|c|c|c|c|c|c|c|c|}
\hline & $\begin{array}{l}\text { (1) Discordo } \\
\text { Totalmente }\end{array}$ & (2) & (3) & Indifferente & (5) & (6) & $\begin{array}{c}\text { (7) } \\
\text { Concordo } \\
\text { Totalmente }\end{array}$ \\
\hline Expectativa & 0 & $\mathrm{O}$ & 0 & 0 & 0 & $\bigcirc$ & $\bigcirc$ \\
\hline $\begin{array}{l}\text { Grau de } \\
\text { Relevância }\end{array}$ & 0 & 0 & $\bigcirc$ & 0 & 0 & 0 & 0 \\
\hline
\end{tabular}


10.Os serviços prestados por uma instituição pública de pesquisa deveriam atender o interesse público *

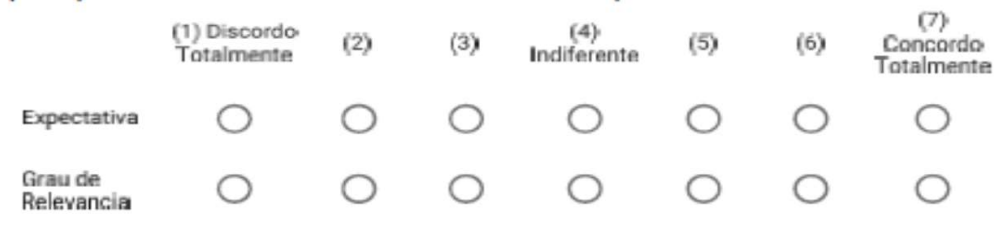

11.Os serviços prestados por uma instituição de pesquisa de excelência deveriam atender aos usuários (interno e externo) conforme prometido *

\begin{tabular}{|c|c|c|c|c|c|c|}
\hline & $\begin{array}{l}\text { (1) Discordo } \\
\text { Totalmente }\end{array}$ & (2) & (3) & $\begin{array}{c}\text { (4) } \\
\text { Indiferente }\end{array}$ & (5) & $\begin{array}{c}\text { (7) } \\
\text { Concordo } \\
\text { Totalmente }\end{array}$ \\
\hline Expectativa & & & & & & \\
\hline $\begin{array}{l}\text { Grau de } \\
\text { Relevancia }\end{array}$ & & & & & & \\
\hline
\end{tabular}

12.Os serviços prestados por uma instituição de pesquisa de excelência deveriam ser concluídos dentro do prazo previsto *

\begin{tabular}{|c|c|c|c|c|c|c|c|}
\hline & $\begin{array}{l}\text { (1) Discordo } \\
\text { Totalmente }\end{array}$ & (2) & (3) & Indifernente & (5) & (6) & $\begin{array}{c}\text { (7) } \\
\text { Concordo } \\
\text { Totalmente }\end{array}$ \\
\hline Expectativa & 0 & 0 & $\bigcirc$ & 0 & 0 & 0 & 0 \\
\hline $\begin{array}{l}\text { Grau de } \\
\text { Relevância }\end{array}$ & $\mathrm{O}$ & $\bigcirc$ & $\bigcirc$ & $\mathrm{O}$ & 0 & $\bigcirc$ & 0 \\
\hline
\end{tabular}

13.Os usuários de uma instituição de pesquisa de excelência deveriam ser informados sobre os prazos para realização dos serviços *
(1) Discordo
Totlamente
(2)
(3) Insifferente
(5) (6) Concordo
Expectativa

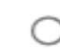
Grau de
Relevância
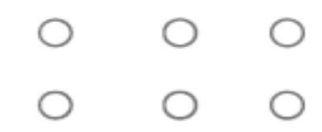

14.Uma instituição de pesquisa de excelência deveria ser ágil na solução dos problemas dos usuários (interno e externo) *
(1) Discordo
(2)
(3) Indiferente
(5)
(6) Concordo
Expectativa

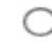
$\bigcirc \quad$
Grau de

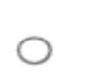
○ 0

15.Em uma instituição de pesquisa de excelência deveria haver mais disponibilidade por parte dos servidores para atender os usuários *
(1) Discordo
Totalmente
(2) (3) Indiferente
(5) (6) $\begin{gathered}(7) \\ \text { concordo } \\ \text { Totalmente }\end{gathered}$
Expectativa
$\mathrm{O}$
○
$\bigcirc 0$
Grau de
Relevância 
16.Em uma instituição de pesquisa de excelência os servidores deveriam oferecer mais de uma solução para o mesmo serviço contratado*

$$
\begin{gathered}
\text { (1) Discordo (2) (3) Indiferente (5) (4) } \\
\text { Totalmente }
\end{gathered} \begin{gathered}
\text { (7) } \\
\text { Toncordo } \\
\text { Totalmente }
\end{gathered}
$$

$\begin{array}{llllllll}\text { Expectativa } & \mathrm{O} & \mathrm{O} & \mathrm{O} & \mathrm{O} & \mathrm{O} & \mathrm{O} & \\ \begin{array}{llllll}\text { Girau de } \\ \text { Relevância }\end{array} & \mathrm{O} & \mathrm{O} & \mathrm{O} & \mathrm{O} & \mathrm{O} & \mathrm{O} & \end{array}$

17.Os servidores de uma instituição pública de excelência deveriam possuir conhecimento amplo nas áreas que atuam *

$$
\begin{array}{ccccc}
\text { (1) Discordo } & \text { (2) } & \text { (3) } & \text { (7) } \\
\text { Totalmente } & \text { Indiferente } & \text { (5) } & \text { (6) } \begin{array}{c}
\text { Concordo } \\
\text { Totalmente }
\end{array}
\end{array}
$$

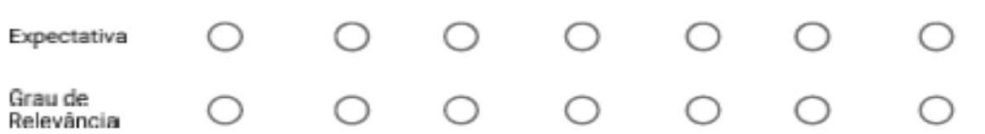

18.As dúvidas dos usuários deveriam ser sanadas integralmente por uma instituição de pesquisa de excelência *

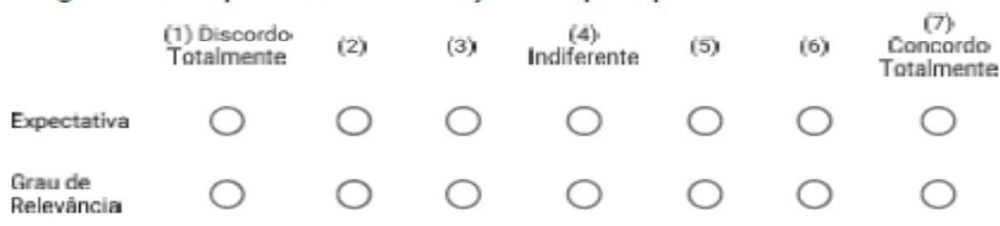

19.As informações passadas pelos servidores de uma instituição de pesquisa de excelência deveriam ser precisas e corretas *

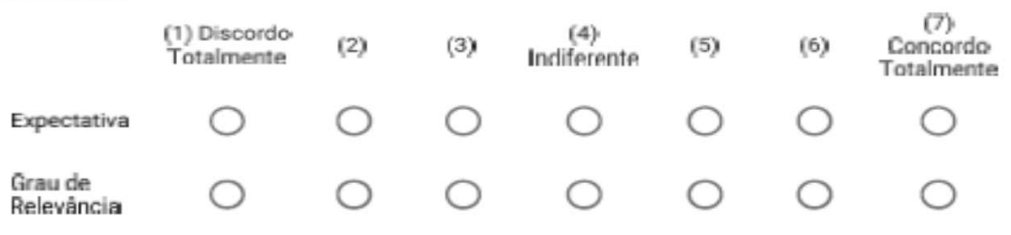

20.Os usuários deveriam receber atendimento personalizado pelos servidores de uma instituição de pesquisa de excelência *

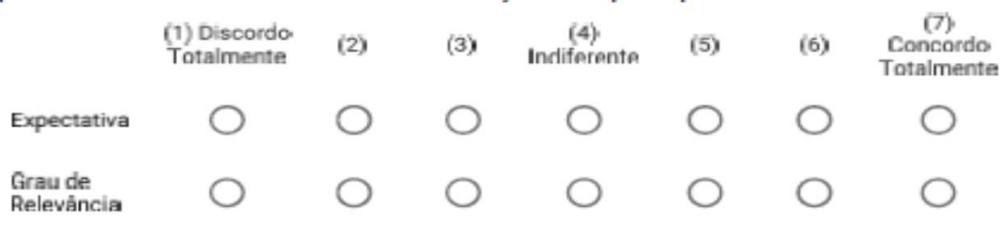

21. Os usuários deveriam ser tratados de maneira atenciosa

\begin{tabular}{|c|c|c|c|c|c|c|c|}
\hline & $\begin{array}{l}\text { (1) Discordo } \\
\text { Totalmente }\end{array}$ & (2) & (3) & $\begin{array}{c}(4) \\
\text { Indiferente }\end{array}$ & (5) & (6) & $\begin{array}{c}\text { (7) } \\
\text { Concordo } \\
\text { Totalmente }\end{array}$ \\
\hline Expectativa & 0 & 0 & $\bigcirc$ & 0 & $\bigcirc$ & $\mathrm{O}$ & 0 \\
\hline $\begin{array}{l}\text { Girau de } \\
\text { Relevância }\end{array}$ & 0 & 0 & 0 & 0 & 0 & 0 & 0 \\
\hline
\end{tabular}
pelos servidores de uma instituição de pesquisa de excelência * 
22.0s servidores de uma instituição de pesquisa de excelência deveriam demonstrar interesse em solucionar os problemas dos usuários *

$$
\begin{array}{llll}
\text { (1) Discordo (3) } & \text { (3) Indiferente } & \text { (5) } & \text { (7) } \\
\text { Totalmente } & \text { (6) Concordo }
\end{array}
$$

Expectativa

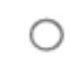

$\bigcirc O$

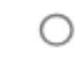

Grau de

Relevância

O

$\bigcirc O$

O

Idade *

$$
18 \text { a } 28 \text { anos } 29 \text { a } 38 \text { anos } 39 \text { a } 48 \text { anos } 49 \text { a } 59 \text { anos Acima de } 59
$$

Faixa etária

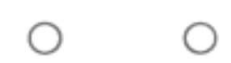

$\bigcirc \quad 0$

Escolaridade: *

Nivel Médio Superior Mestrado Doutorado

Nivel de Fscolaridade

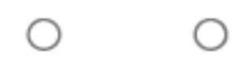

$\mathrm{O}$

\author{
Instituição em que trabalha * \\ Sua resposta \\ Área de Atuação *

$$
\text { Área Técnica Área Administrativa Usuário Externo }
$$ \\ Linha 1 \\ $\mathrm{O}$
}

Gênero: *

Masculino Ferninino

Linha 1

○

○

ENVIAR

Nunca envie senhas pelo Formulários Google.

Este conteúdo năo foi criado nem aprovado pelo Google. Denunciar abuso - Termos de Serviço - Termos Adicionais

Google Forms 


\section{Percepção dos usuários (interno e externo)quanto à "qualidade" dos serviços prestados pelo IPEA}

DRIENTACŌES:

As informaçōes que se seguem estão relacionadas ao IPEA. Por favor, dễ a sua opiniāo acerca das suas características e do modo de funcionamento, no âmbito da qualidade da prestaçấo de: serviços. Nas perguntas de múltipla escolha, em cada afirmaçäo, selecione na escala de 1 a 7 a opçäo escolhida, de acordo com o grau de relevância face ao exposto. Marque o número da sua escolha. Quanto maior a relevåncia, maior o número; quanto menor a relevảncia, menor o número. Nẫo existem respostas certas ou erradas, pois o interesse do estudo é apenas identificar um número que melhor traduza a qualidade dos serviços prestados pelo IPEA e a importancia atribuida a cada fator ou caracteristica exposta.

*Obrigatório

1.0 IPEA, como instituição pesquisa de excelência, dispõe de instalações físicas modernas *

\begin{tabular}{|c|c|c|c|c|c|c|c|}
\hline & $\begin{array}{l}\text { (1) Discordo } \\
\text { Totalmente }\end{array}$ & (2) & (3) & $\begin{array}{c}(4) \\
\text { Indiferente }\end{array}$ & (5) & (6) & $\begin{array}{c}\text { (7) } \\
\text { Concordo } \\
\text { Totalmente }\end{array}$ \\
\hline Percepçāo & & & & & & & \\
\hline
\end{tabular}

2.0 IPEA, como instituição pesquisa de excelência, dispõe de acervo e repositórios do conhecimento modernos e atualizados *

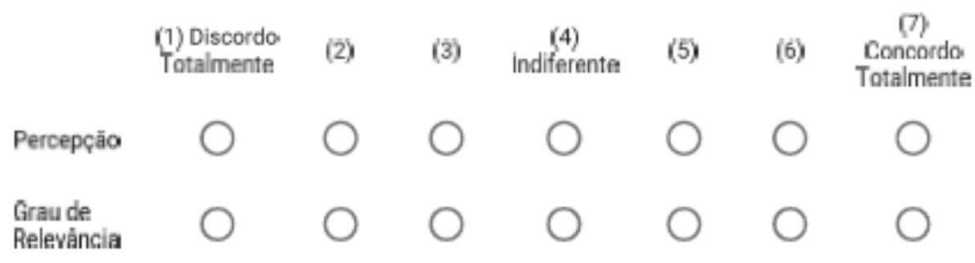

3.0 IPEA, como instituição pesquisa de excelência, dispõe de equipamentos de informática modernos e base de dados atualizada *
(1) Discordo
(2)
(3) Indiferente
(5)
(6) Concordo Totalmente

Percepção

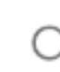

0

O

0

Grau de

Relevância 
4.Os servidores do IPEA, como instituição pesquisa de excelência, têm boa apresentação *

\begin{tabular}{|c|c|c|c|c|c|c|c|}
\hline & $\begin{array}{l}\text { (1) Discordo } \\
\text { Totalmente }\end{array}$ & (2) & (3) & $\begin{array}{l}(4) \\
\text { Indiferente }\end{array}$ & (5) & (6) & $\begin{array}{c}\text { (7) } \\
\text { Concordo } \\
\text { Totalmente }\end{array}$ \\
\hline Percepçāo & 0 & $\bigcirc$ & 0 & 0 & 0 & 0 & 0 \\
\hline $\begin{array}{l}\text { rau de } \\
\text { elevância }\end{array}$ & 0 & $\bigcirc$ & 0 & 0 & 0 & 0 & $\bigcirc$ \\
\hline
\end{tabular}

5.O IPEA, como instituição pesquisa de excelência, tem sua área de atuação bem delimitada *

\begin{tabular}{|c|c|c|c|c|c|c|c|}
\hline & $\begin{array}{l}\text { (1) Discordo } \\
\text { Totalmente }\end{array}$ & (2) & (3) & $\begin{array}{c}(4) \\
\text { Indiferente }\end{array}$ & (5) & (6) & $\begin{array}{c}\text { (7) } \\
\text { Concordo } \\
\text { Totalmente }\end{array}$ \\
\hline Percepçāo & 0 & 0 & 0 & 0 & 0 & 0 & 0 \\
\hline $\begin{array}{l}\text { rrau de } \\
\text { elevảncia }\end{array}$ & 0 & 0 & 0 & 0 & 0 & 0 & 0 \\
\hline
\end{tabular}

6.O IPEA, como instituição pesquisa de excelência, apresenta seus trabalhos de forma a atender às necessidades dos usuários *

\begin{tabular}{|c|c|c|c|c|c|c|c|}
\hline & $\begin{array}{l}\text { (1) Discordo } \\
\text { Totalmente }\end{array}$ & (2) & (3) & $\begin{array}{l}\text { (4) } \\
\text { Indiferente }\end{array}$ & (5) & (6) & $\begin{array}{c}\text { (7) } \\
\text { Concoordo } \\
\text { Totalmente }\end{array}$ \\
\hline Percepçāo & 0 & $\bigcirc$ & $\bigcirc$ & $\bigcirc$ & $\bigcirc$ & 0 & 0 \\
\hline $\begin{array}{l}\text { Grau de } \\
\text { Televanncia }\end{array}$ & 0 & 0 & $\bigcirc$ & 0 & 0 & 0 & 0 \\
\hline
\end{tabular}

7.Os trabalhos desenvolvidos pelo IPEA, como instituição pesquisa de excelência, influenciam bastante nas tomadas de decisões *

\begin{tabular}{|c|c|c|c|c|c|c|c|}
\hline & $\begin{array}{l}\text { (1) Discordo } \\
\text { Totalmente }\end{array}$ & (2) & (3) & $\stackrel{(4)}{\text { Indifferente }}$ & (5) & (6) & $\begin{array}{c}\text { (7) } \\
\text { Concordo } \\
\text { Totalmente }\end{array}$ \\
\hline Percepçāo & 0 & 0 & 0 & 0 & 0 & O & 0 \\
\hline $\begin{array}{l}\text { irau de } \\
\text { elevảncila }\end{array}$ & 0 & 0 & 0 & 0 & 0 & 0 & 0 \\
\hline
\end{tabular}

8.O IPEA, como instituição pública de pesquisa de excelência, contribui muito com melhoria na qualidade das decisões do Governo Central *

\begin{tabular}{|c|c|c|c|c|c|c|c|}
\hline & $\begin{array}{l}\text { (1) Discordo } \\
\text { Totalimente }\end{array}$ & (2) & (3) & Indifferente & $(5)$ & (6) & $\begin{array}{c}\text { (7) } \\
\text { Concordo } \\
\text { Totalmente }\end{array}$ \\
\hline Percepçäo & 0 & 0 & 0 & 0 & 0 & 0 & $\bigcirc$ \\
\hline $\begin{array}{l}\text { Grau de } \\
\text { televância }\end{array}$ & 0 & 0 & 0 & 0 & 0 & 0 & 0 \\
\hline
\end{tabular}

9.As pesquisas do IPEA, como instituição de pesquisa de excelência, contribuem muito para a qualificação do debate público *

\begin{tabular}{|c|c|c|c|c|c|c|c|}
\hline & $\begin{array}{l}\text { (1) Discordo } \\
\text { Totalmente }\end{array}$ & (2) & (3) & $\begin{array}{l}(4) \\
\text { Indifferente }\end{array}$ & (5) & (6) & $\begin{array}{c}\text { (7) } \\
\text { Concordo } \\
\text { Totalmente }\end{array}$ \\
\hline Percepçāo & 0 & 0 & 0 & $\bigcirc$ & 0 & 0 & 0 \\
\hline Girau de & 0 & 0 & 0 & 0 & 0 & 0 & 0 \\
\hline
\end{tabular}


10.Os serviços prestados pelo IPEA, como instituição pública de pesquisa de excelência, atendem o interesse público *

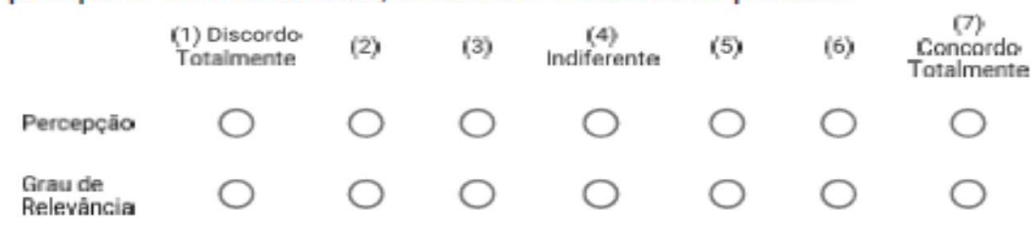

11.Os serviços prestados pelo IPEA, como instituição pesquisa de excelência, atendem aos usuários conforme prometido *

\begin{tabular}{|c|c|c|c|c|c|c|c|}
\hline & $\begin{array}{l}\text { (1) Discordo } \\
\text { Totalmente }\end{array}$ & (2) & (3) & $\begin{array}{c}(4) \\
\text { Indiferente }\end{array}$ & (5) & (6) & $\begin{array}{c}\text { (7) } \\
\text { Concordo } \\
\text { Totalmente }\end{array}$ \\
\hline Percepçāo & 0 & 0 & 0 & 0 & 0 & 0 & 0 \\
\hline $\begin{array}{l}\text { Grau de } \\
\text { Relevância }\end{array}$ & 0 & 0 & 0 & 0 & 0 & 0 & 0 \\
\hline
\end{tabular}

12.Os serviços prestados pelo IPEA, como instituição pesquisa de excelência, são concluídos dentro do prazo previsto *

\begin{tabular}{|c|c|c|c|c|c|c|c|}
\hline & $\begin{array}{l}\text { (1) Discordo } \\
\text { Totalmente }\end{array}$ & (2) & (3) & $\begin{array}{c}(4) \\
\text { Indiferente }\end{array}$ & (5) & (6) & $\begin{array}{c}\text { (7) } \\
\text { Concordo } \\
\text { Totalmente }\end{array}$ \\
\hline Percepção & 0 & $\bigcirc$ & 0 & 0 & 0 & 0 & 0 \\
\hline $\begin{array}{l}\text { Grau de } \\
\text { Relevância }\end{array}$ & 0 & $\bigcirc$ & 0 & 0 & 0 & 0 & 0 \\
\hline
\end{tabular}

13.Os usuários do IPEA, como instituição de pesquisa de excelência, são informados sobre os prazos para realização dos serviços *

\begin{tabular}{|c|c|c|c|c|c|c|c|}
\hline & $\begin{array}{l}\text { (1) Discordo } \\
\text { Totalmente }\end{array}$ & (2) & (3) & $\begin{array}{c}(4) \\
\text { Indifferente }\end{array}$ & (5) & (6) & $\begin{array}{c}\text { (7) } \\
\text { Concordo } \\
\text { Totalmente }\end{array}$ \\
\hline Percepçāo & 0 & 0 & 0 & 0 & 0 & 0 & $\bigcirc$ \\
\hline $\begin{array}{l}\text { Girau de } \\
\text { Relevância }\end{array}$ & 0 & $\bigcirc$ & $\bigcirc$ & 0 & 0 & 0 & 0 \\
\hline
\end{tabular}

14.O IPEA, como instituição de pesquisa de excelência, é ágil na solução dos problemas dos usuários (interno e externo) *

\begin{tabular}{|c|c|c|c|c|c|c|c|}
\hline & $\begin{array}{l}\text { (1) Discordo } \\
\text { Totalimente }\end{array}$ & (2) & (3) & $\stackrel{(4)}{\text { Indifferente }}$ & (5) & (6) & $\begin{array}{c}\text { (7) } \\
\text { Concordo } \\
\text { Totalmente }\end{array}$ \\
\hline Percepçāo & 0 & 0 & 0 & 0 & 0 & 0 & 0 \\
\hline $\begin{array}{l}\text { Girau de } \\
\text { Relevância }\end{array}$ & 0 & 0 & $\bigcirc$ & 0 & 0 & 0 & 0 \\
\hline
\end{tabular}

15.No IPEA, como instituição pesquisa de excelência, há mais disponibilidade por parte dos servidores para atender os usuários *

\begin{tabular}{|c|c|c|c|c|c|c|c|}
\hline & $\begin{array}{l}\text { (1) Discordo } \\
\text { Totalmente }\end{array}$ & (2) & (3) & Indiferente & (5) & (6) & $\begin{array}{c}(7) \\
\text { Concordo } \\
\text { Totalmente }\end{array}$ \\
\hline ercepçäo & 0 & 0 & 0 & 0 & 0 & 0 & 0 \\
\hline $\begin{array}{l}\text { rau de } \\
\text { elevância }\end{array}$ & 0 & 0 & 0 & 0 & $\bigcirc$ & 0 & 0 \\
\hline
\end{tabular}


16.No IPEA, como uma instituição de pesquisa de excelência, os servidores oferecem mais de uma solução para o mesmo serviço contratado *

\begin{tabular}{|c|c|c|c|c|c|c|c|}
\hline & $\begin{array}{l}\text { (1) Discordo } \\
\text { Totalmente }\end{array}$ & (2) & (3) & Indiferente & (5) & (6) & $\begin{array}{c}\text { (7) } \\
\text { Concordo } \\
\text { Totalmente }\end{array}$ \\
\hline Percepçāo & 0 & 0 & 0 & 0 & 0 & 0 & 0 \\
\hline $\begin{array}{l}\text { Grau de } \\
\text { Relevância }\end{array}$ & 0 & 0 & 0 & 0 & 0 & 0 & 0 \\
\hline
\end{tabular}

17.Os servidores do IPEA, como uma instituição pública de excelência, possuem conhecimento amplo nas áreas em que atuam *

\begin{tabular}{|c|c|c|c|c|c|c|c|}
\hline & $\begin{array}{l}\text { (1) Discordo } \\
\text { Totalmente. }\end{array}$ & (2) & (3) & $\begin{array}{l}\text { (4) } \\
\text { Indifernete }\end{array}$ & (5) & (6) & $\begin{array}{c}(7) \\
\text { Comcordo } \\
\text { Totalmente }\end{array}$ \\
\hline Percepçāo & 0 & 0 & 0 & 0 & 0 & 0 & 0 \\
\hline $\begin{array}{l}\text { Grau de } \\
\text { Relevância }\end{array}$ & 0 & 0 & 0 & 0 & 0 & 0 & 0 \\
\hline
\end{tabular}

18.As dúvidas dos usuários são sanadas integralmente pelo IPEA, como uma instituição de pesquisa de excelência *

\begin{tabular}{|c|c|c|c|c|c|c|c|}
\hline & $\begin{array}{l}\text { (1) Discordo } \\
\text { Totalmente }\end{array}$ & (2) & (3) & $\begin{array}{l}(4) \\
\text { Indiferente }\end{array}$ & (5) & (6) & $\begin{array}{c}\text { (7) } \\
\text { Concordo } \\
\text { Totalmente }\end{array}$ \\
\hline Percepçāo & 0 & 0 & 0 & 0 & 0 & 0 & 0 \\
\hline $\begin{array}{l}\text { Grau de } \\
\text { Relevância }\end{array}$ & 0 & 0 & 0 & 0 & 0 & 0 & 0 \\
\hline
\end{tabular}

19.As informações passadas pelos servidores do IPEA, como uma instituição de pesquisa de excelência, são precisas e corretas *

\begin{tabular}{|c|c|c|c|c|c|c|c|}
\hline & $\begin{array}{l}\text { (1) Discordo } \\
\text { Totiamente }\end{array}$ & (2) & (3) & $\begin{array}{l}\text { (4) } \\
\text { Indifferente }\end{array}$ & (5) & (6) & $\begin{array}{c}(7) \\
\text { Concordo } \\
\text { Totalmente }\end{array}$ \\
\hline Percepçāa & 0 & $\bigcirc$ & $\bigcirc$ & 0 & 0 & 0 & $\bigcirc$ \\
\hline $\begin{array}{l}\text { Grau de } \\
\text { Relevância }\end{array}$ & 0 & $\bigcirc$ & 0 & 0 & $\bigcirc$ & 0 & $\bigcirc$ \\
\hline
\end{tabular}

20.Os usuários recebem atendimento personalizado pelos servidores do IPEA, como uma instituição de pesquisa de excelência *

\begin{tabular}{|c|c|c|c|c|c|c|c|}
\hline & $\begin{array}{l}\text { (1) Discordo } \\
\text { Totalmente }\end{array}$ & (2) & (3) & Indifferente & (5) & (6) & $\begin{array}{c}\text { (7) } \\
\text { Concordo } \\
\text { Totalmente }\end{array}$ \\
\hline Percepçāo & 0 & 0 & 0 & 0 & 0 & 0 & 0 \\
\hline $\begin{array}{l}\text { Grau de } \\
\text { Relevância }\end{array}$ & 0 & 0 & 0 & 0 & 0 & 0 & 0 \\
\hline
\end{tabular}

21.Os usuários são tratados de maneira atenciosa pelos servidores do IPEA, como uma instituição de pesquisa de excelência *
(1) Discordo
Totalmente
(2)
(3) Indiferente
(5)

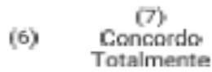
Percepçāo
$\mathrm{O}$
$\bigcirc \bigcirc$
Grau de

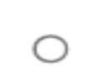


22.0s servidores do IPEA, como uma instituição de pesquisa de excelência, demonstram interesse em solucionar os problemas dos usuários *

$\begin{aligned} & \text { (1) Discordo } \\ & \text { Totalmente }\end{aligned}$
$\begin{aligned} & \text { Gercepçāo } \\ & \text { Relevância }\end{aligned}$
Idade *

Instituição em que trabalha *

Sua resposta

Área de Atuação *

Área Técnica Área Administrativa Usuário Externo

Linha 1

O

$\bigcirc$

O

Gênero *

Masculino Ferninino

Linha 1

ENVIAR

Nunca envie senhas pelo Formulários Google.

Este conteúdo näo foi criado nem aprovado pelo Google. Denunciar abuso - Termos de Serviço - Termos Adicionais 